OECDpublishing

FISCAL CHALLENGES AND

INCLUSIVE GROWTH IN

AGEING SOCIETIES

OECD ECONOMIC

POLICY PAPER

September 2019 No. 27 
Economic Policy Paper No. 27

\title{
FISCAL CHALLENGES AND INCLUSIVE GROWTH IN AGEING SOCIETIES
}

This paper has been prepared by:

\author{
Dorothée Rouzet \\ Aida Caldera Sánchez \\ Théodore Renault \\ Oliver Roehn
}

Authorised for publication by Laurence Boone Chief Economist and G20 Finance Deputy 
The OECD Economic Policy Paper Series is published on the responsibility of the Secretary-General of the OECD. The opinions expressed and arguments employed herein do not necessarily reflect the official views of the Organisation or of the governments of its member countries.

Series: OECD Economic Policy Papers

ISSN 2226583X

Dorothée Rouzet, Aida Caldera Sánchez and Oliver Roehn are in the Economics Department. At the time of writing this paper, Théodore Renault was in the Economics Department. The paper was prepared in support of the Japanese G20 Presidency's priority on ageing and its policy implications. The authors would like to thank Pablo Antolin, Sebastian Barnes, Laurence Boone, Hervé Boulhol, Boris Cournède, Yvan Guillemette, Jens-Christian Hoj, Mark Keese, Isabell Koske, Monika Queisser, Gabriela Ramos, Michele Rimini and Angelica Salvi del Pero for very helpful comments and discussions, and members of the G20 Framework Working Group for constructive feedback. They are also grateful to colleagues in the Economics Department Country Studies branch for material related to recent reforms and to Penny Elghadab for excellent editorial assistance.

On 3 May 2018, the OECD Council invited Lithuania to become a Member. At the time of preparation, the deposit of Lithuania's instrument of accession to the OECD Convention was pending and therefore Lithuania does not appear in the list of OECD Members and is not included in the OECD zone aggregates.

On 25 May 2018, the OECD Council invited Colombia to become a Member. At the time of preparation, the deposit of Colombia's instrument of accession to the OECD Convention was pending and therefore Colombia does not appear in the list of OECD Members and is not included in the OECD zone aggregates.

This document and any map included herein are without prejudice to the status of or sovereignty over any territory, to the delimitation of international frontiers and boundaries and to the name of any territory, city or area.

\section{(C) OECD 2019}

You can copy, download or print OECD content for your own use, and you can include excerpts from OECD publications, databases and multimedia products in your own documents, presentations, blogs, websites and teaching materials, provided that suitable acknowledgment of OECD as source and copyright owner is given. All requests for public or commercial use and translation rights should be submitted to rights@oecd.org. Requests for permission to photocopy portions of this material for public or commercial use shall be addressed directly to the Copyright Clearance Center (CCC) at info@copyright.com or the Centre français d'exploitation du droit de copie (CFC) at contact@cfcopies.com. 


\section{Table of contents}

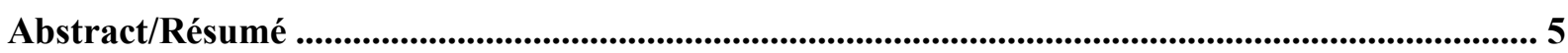

Fiscal challenges and inclusive growth in ageing societies...........................................................6

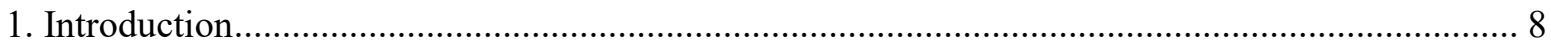

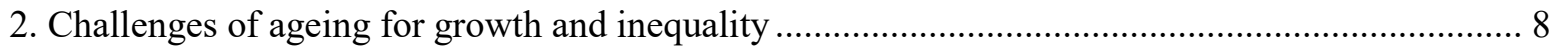

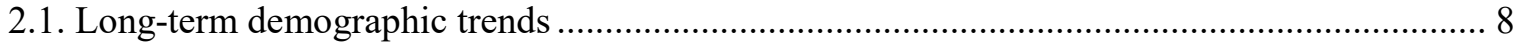

2.2. Ageing is affecting the prospects for growth and inclusiveness .......................................... 11

2.2.1. Changes in population growth and the age structure of the population will weigh on

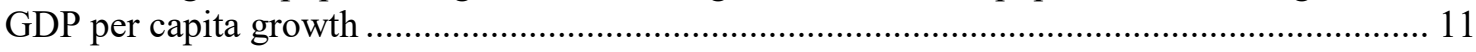

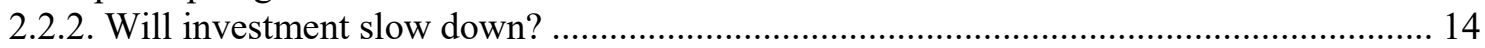

2.2.3. The effect of ageing on productivity and incomes is uncertain ..................................... 16

2.2.4. Intra- and inter-generational inequalities could be exacerbated .................................... 16

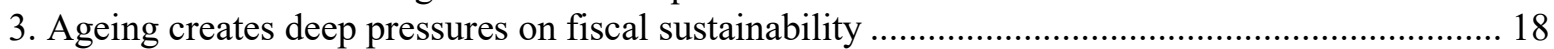

3.1. Sustainability of unfunded public pensions and social security systems .............................. 19

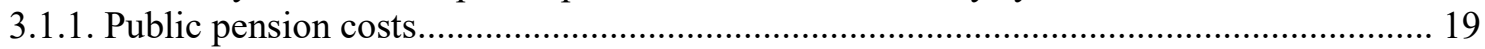

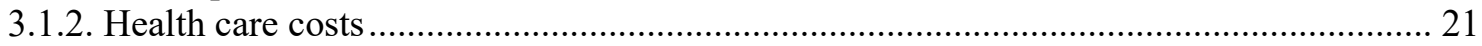

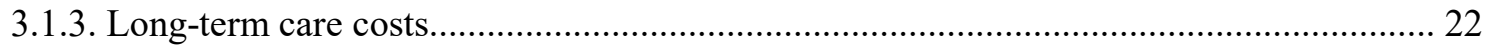

3.1.4. Combined fiscal stress from ageing-related spending ................................................... 23

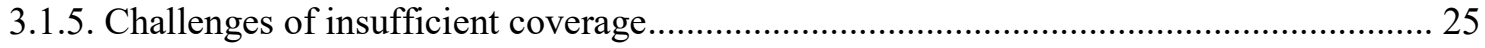

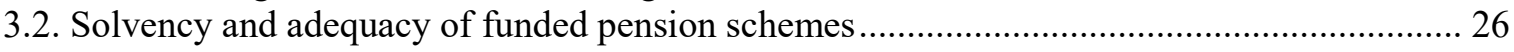

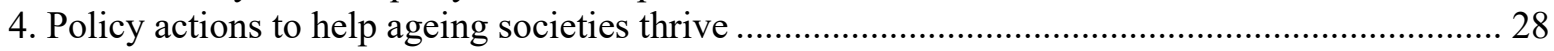

4.1. Promoting financially sustainable pension, health and long-term care systems .................... 28

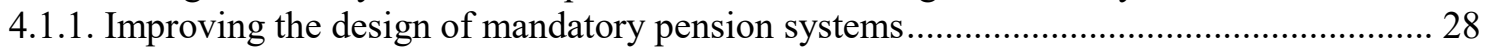

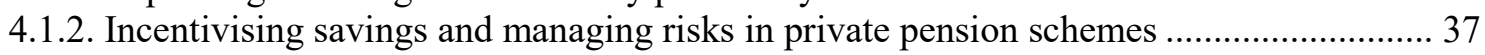

4.1.3. Promoting healthy ageing and containing costs in the health sectors............................. 39

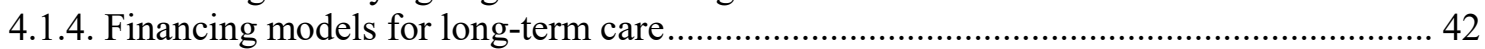

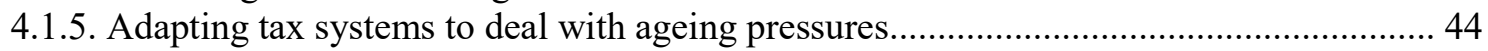

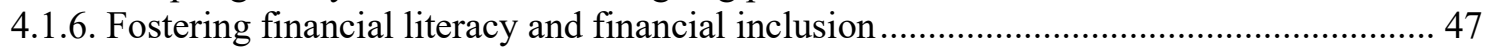

4.2. Lifting employment and productivity in ageing societies ....................................................... 49

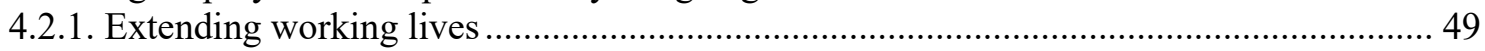

4.2.2. Ensuring that older workers' skills remain well adapted to labour market needs ............. 51

4.2.3. Expanding the labour supply of low-skilled workers, women and youth..........................53

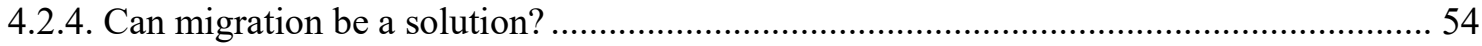

4.2.5. Leveraging the "silver economy" for entrepreneurship and innovation ........................... 56

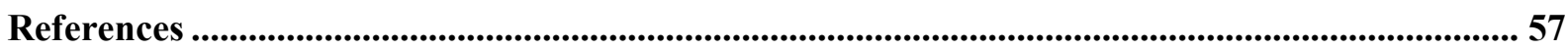

\section{Tables}

Table 1. Projections of public expenditure on pensions, 2013-2060, \% of GDP ................................ 21

Table 2. Government non-tax financial incentives in OECD countries .............................................. 38

Table 3. Structure of retirement-income provision in G20 countries, public and mandatory schemes. 64

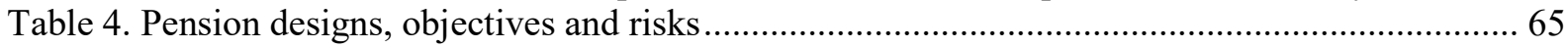

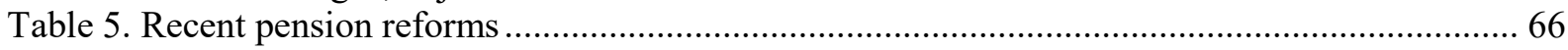




\section{Figures}

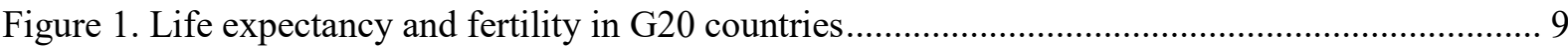

Figure 2. Old-age dependency ratios are projected to at least double in most G20 countries............... 10

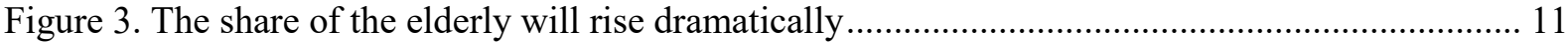

Figure 4. Ageing will weigh on global real GDP per capita growth ................................................... 12

Figure 5 Ageing will weigh on living standards in most G20 countries ........................................... 12

Figure 6. Employment rates at age 55-64 have increased since 2000 in most economies .................... 13

Figure 7. Gaps in employment rates at age 55-64 by education persist ........................................... 13

Figure 8. Increases in wage inequality increase pension inequality ................................................. 17

Figure 9. The poverty risk is highest above 75, especially for women .......................................... 18

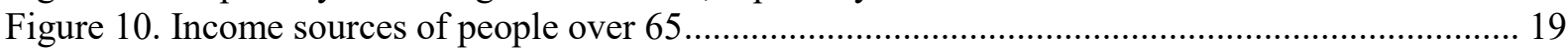

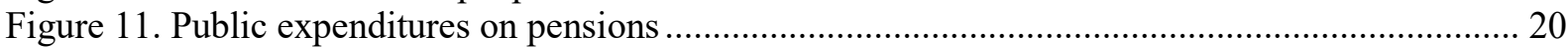

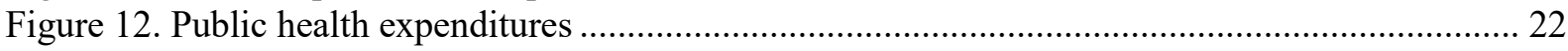

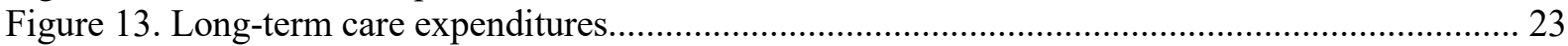

Figure 14. Change in tax revenue necessary by 2060 to stabilise debt ratios at current levels ............. 24

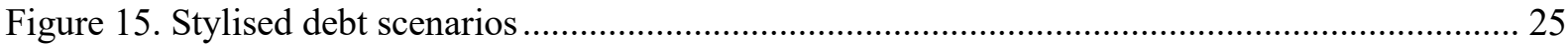

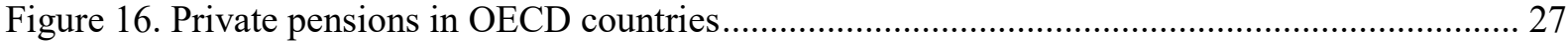

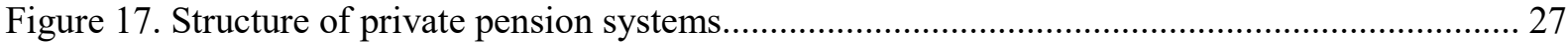

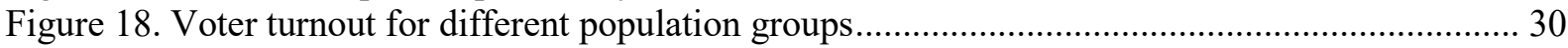

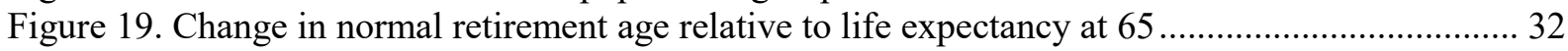

Figure 20. The retirement age will increase in about half of G20 economies..................................... 33

Figure 21. Increase in GDP per capita by 2030 if minimum and statutory retirement ages rise by at

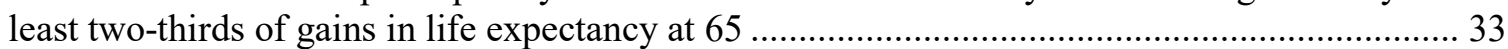

Figure 22. Projected future net replacement rates from mandatory pension schemes ......................... 35

Figure 23. Mandatory pension contribution rates for an average worker in 2016 ............................... 36

Figure 24. Health worsens with age, especially for lower educated people .......................................... 40

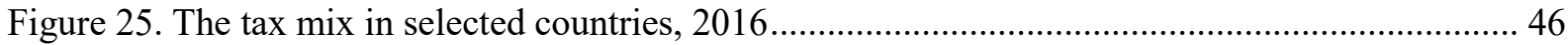

Figure 26. Many people do not have basic financial literacy, especially women ................................ 48

Figure 27. Older workers lack IT skills, but participate less in training ........................................... 52

Figure 28. The gender gap in employment rates has been reduced, but remains high in some countries

\section{Boxes}

Box 1. Demographics and interest rates: Is ageing a driver of "secular stagnation"? ............................ 15

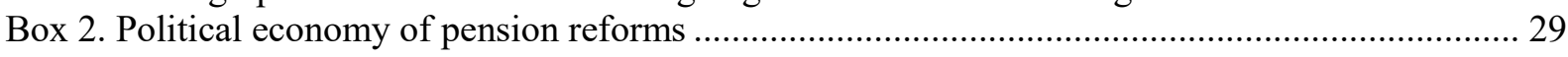

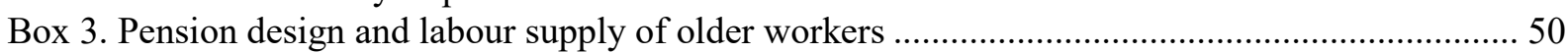




\section{Abstract/Résumé}

\section{Fiscal challenges and inclusive growth in ageing societies}

This paper was prepared in support of Japan's G20 Presidency. It takes stock of ongoing and projected population ageing across G20 economies and its far-reaching implications for economic growth, productivity, inequality within and between generations and the sustainability of public finances. Rising old-age dependency ratios will put the financing of adequate pensions, health and long-term care under high pressure. The paper provides recommendations on policy responses to address ageing-related challenges and highlights good practices. A comprehensive approach is needed, tailored to each country's institutional and policy settings and social preferences, and may span many areas of public policy: improving the design of public pensions, incentivising private savings, enhancing the efficiency of health care provision, expanding the coverage of social security systems, promoting employability and skills of older workers, and striving for a better labour market inclusion of women, youth and migrants.

JEL classification codes: E24, H51, H55, J11, J26

Keywords: ageing, pensions, health, long-term care, fiscal sustainability, employment, skills, inequality

$* * * * * * * * * * * * * * * * * * *$

Défis pour les finances publiques et croissance inclusive dans des sociétés vieillissantes

Ce document a été préparé en appui à la présidence du G20 du Japon. Il examine le vieillissement en cours et à venir des populations dans les économies du G20, et ses profondes répercussions pour la croissance, la productivité, les inégalités au sein des générations et entre elles, et la soutenabilité des finances publiques. L'accroissement des ratios de dépendance des personnes âgées exercera une forte pression sur le financement des retraites, de la santé et des soins de longue durée. Ce document formule des recommandations sur les réponses que les politiques publiques peuvent apporter aux défis $\mathrm{du}$ vieillissement des populations, et met en avant de bonnes pratiques. Une approche globale est nécessaire, adaptée aux conditions institutionnelles et politiques ainsi qu'aux préférences sociales de chaque pays. Une telle réponse peut relever de nombreux domaines de l'action publique: réformer les régimes de retraite, encourager l'épargne privée, améliorer l'efficacité des services de santé, promouvoir l'emploi et les compétences des travailleurs seniors, et agir pour une meilleure insertion des femmes, des jeunes et des migrants sur le marché du travail.

Classification JEL : E24, H51, H55, J11, J26

Mots-clés: vieillissement, retraites, santé, soins de longue durée, soutenabilité fiscale, emploi, compétences, inégalités 


\section{Fiscal challenges and inclusive growth in ageing societies}

\section{Key messages}

This paper takes stock of ongoing and projected ageing of societies and their implications for economic growth, productivity, inequality and the sustainability of public finances. It discusses possible policy responses to address the challenges of demographic change in G20 economies, and to promote the G20 objective of strong, sustainable, balanced and inclusive growth in ageing societies.

- Populations are ageing rapidly across advanced economies and many emerging market economies because of rising life expectancy and declining fertility, although at different speeds. The number of people over 65 for each working-age person will at least double in most G20 countries by 2060 , and the share of people over 80 in the world's population will triple. The slowing growth of the working-age population will weigh on GDP per capita growth in the coming decades in most economies, especially if shrinking and ageing populations result in slower investment and productivity growth.

- Those who are currently young may face higher inequality and poverty risk in their old age than older generations, as they are expected to spend more years on retirement income and as the less privileged accumulate disadvantages over their life course. These disadvantages include more unstable labour market conditions and poorer earnings observed in many countries.

- Rising old-age dependency ratios will put unprecedented stress on the financing of public pensions, health and long-term care, especially in a slow growth environment. Absent policy changes, ageing pressures could increase the public debt burden by an average of $180 \%$ of GDP in G20 advanced economies and $130 \%$ of GDP in G20 emerging economies over the next three decades. Alternatively, tax revenue would need to increase by between $4 \frac{1}{2}$ and $11 \frac{1}{2}$ percentage points of GDP by 2060 in G20 countries to stabilise public debt-to-GDP ratios at their current levels.

- Pension reform should address the triple challenge of improving fiscal sustainability and reducing old-age poverty risk, while ensuring a fair sharing of the burden across generations. Advanced economies, where ageing is already well under way, typically face more pressing challenges to finance rising pension costs. Depending on each country's existing pension systems and policy objectives, options include linking the retirement age to life expectancy, allowing for flexible retirement with adequate financial incentives, expanding pension coverage of non-standard workers and improving the adequacy of safety net pensions.

- Low returns compound the ageing-related challenges to the solvency of private pension schemes in defined benefit systems and, together with often-insufficient savings, can lead to poor adequacy of retirement income in defined contribution systems for those with lower socio-economic status. Automatic enrolment, matching contributions by employers or governments or fixed nominal subsidies targeted at these groups, and annuitisation can help incentivise participation and raise aggregate savings. Financial education also needs to be stepped up in many countries for people to make informed 
retirement planning choices. Reliable mortality tables incorporating future improvements in life expectancy would help pension funds deal with longevity risk.

- Rising health and long-term care expenditure will exacerbate the pressure on public finances already strained by rising pension costs. Promoting healthy ageing, containing costs and realising efficiency gains in the health and long-term care sector is crucial to ensure sustainability.

- In many emerging G20 economies, ensuring sufficient coverage of pensions, health and long-term care is the main challenge. Reducing informality will be essential to improve the financing and adequacy of pension and social security systems. Policy action to achieve this goal should rest on three pillars: reducing the costs of formalisation, increasing the perceived benefits of formal employment, and strengthening compliance with regulations through better enforcement.

- To increase employment in ageing societies, policies should tackle barriers to the employment of older workers, such as mandatory retirement, lack of flexible work arrangements and seniority wage-setting. Promoting life-long skills development is a priority to enhance the employability and productivity of senior workers, in particular through training in the use of digital technologies.

- Improving the labour force inclusion of women, youth and migrants helps mitigate the consequences of ageing on the financing of pensions, and can reduce old-age inequality and poverty. Policies that help reconcile work and family commitments are key to encourage female labour force participation and can also have a positive effect on fertility.

- Ageing will create new opportunities for technology to respond to unmet needs of the elderly and improve health care. Countries where policy conditions enable innovation and entrepreneurship to thrive will be best placed to benefit from the "silver economy". 


\section{Introduction}

1. Ageing and demographic changes are major driving forces of changes in the economy and society and pose significant macroeconomic challenges. Although the timing and scale differs across countries, most economies are undergoing population ageing, due to gains in life expectancy and declines in fertility rates. Older and shrinking workforces will affect not only labour market outcomes, but also productivity, saving and investment behaviours and interest rates, with spillovers across countries. Rising pension, health and long-term care costs create pressures on public finances, while many private pension saving arrangements are also under financial pressure. At the same time, ageing will have important implications for income and wealth inequality, both within and between generations. As the foundations of inequality are laid early in life, countries with a relatively young population also have an interest in addressing inequalities as early as possible to prevent them from compounding over the life cycle.

2. This paper was prepared in support of Japan's G20 Presidency. The G20 provides a unique forum to examine and monitor key challenges emanating from ageing, and to share experiences on the appropriate and feasible policy measures to mitigate adverse impacts. Many advanced G20 economies are already facing ageing-related challenges and have started to address them. The populations of emerging G20 economies are much younger than in most advanced economies, but some of them are already facing rapid demographic change at a relatively early stage of development and will need to start preparing for these challenges. Considering the diverse pace of ageing across G20 members, there is valuable scope to share perspectives on common challenges and learn from the experiences of those where the ageing process is already advanced.

3. Tackling the challenges from ageing will require multifaceted policy responses spanning areas such as pension and health care systems, skills and labour market reforms to ensure higher employment across all age groups, including among older people. It will also require further progress on on-going G20 efforts in areas such as the Brisbane commitment to reduce the gender gap in labour force participation rates between men and women by $25 \%$ by 2025 or the G20 commitment to advance financial inclusion, in particular underserved and vulnerable groups.

4. This paper takes stock of the on-going and projected ageing of societies and their implications for economic growth, productivity and inequality (section 2) as well as the sustainability of public finances and private pensions (section 3). Possible policy responses to address the challenges of demographic change are discussed (section 4), to promote the G20 objective of strong, sustainable, balanced and inclusive growth in ageing societies.

\section{Challenges of ageing for growth and inequality}

\subsection{Long-term demographic trends}

5. With rising life expectancy and low and declining fertility rates, populations are ageing rapidly across advanced economies and many emerging market economies (EMEs). Advances in health care, rising incomes and increased education and employment of women across the globe have driven these long-term trends. By 2060, all G20 economies are expected to have fertility rates below the replacement level of 2.1 , and to have experienced significant increases in longevity, by an average of 4 years (Figure 1). The working-age population is projected to shrink by about 25 million people in Japan, 12 million in Germany and 300 million 
in China. The baby-boom generation reaching retirement age adds an additional temporary demographic pressure.

Figure 1. Life expectancy and fertility in G20 countries ${ }^{1}$
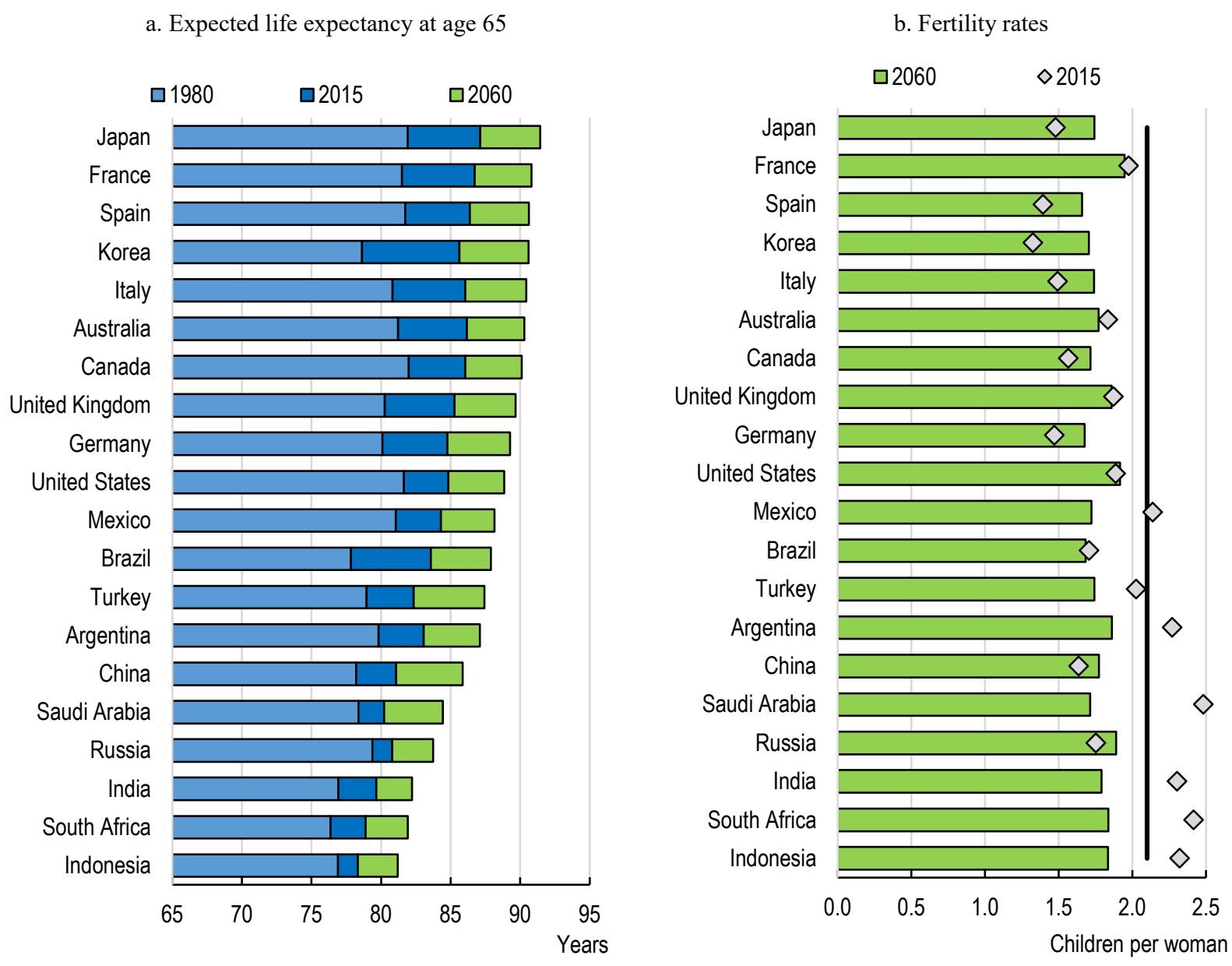

Note: The black line on the right panel corresponds to the replacement level of 2.1 children per woman. Source: United Nations World Population Prospects: The 2017 Revision.

StatLink הत्मा http://dx.doi.org/10.1787/888933973401

6. As a result, absent policy changes, old-age dependency ratios will rise in all G20 members in the next decades, although at different paces (Figure 2). Japan is experiencing the fastest ageing of its population, with 47 people older than 65 per 100 working-age adults in 2015, up from 19 in 1990, and rising to 80 by 2060. Among advanced G20 countries, Italy, Germany and Korea will also face some of the most significant challenges from ageing.

7. Among EMEs, the picture is mixed. Their populations are currently much younger than in most advanced economies, but some EMEs are facing rapid demographic change at a relatively early stage of development. For instance, old-age dependency ratios in Brazil and China were respectively at $13 \%$ and $14.5 \%$ in 2015 , half of the OECD average. By 2060 , Brazil's old-

\footnotetext{
${ }^{1}$ Spain in included in this paper as a permanent invitee of the G20.
} 
age dependency ratio will be close to the OECD average while China's will exceed it (Figure 2). In other EMEs, such as India, South Africa and Indonesia, populations will age more slowly. For these countries, the challenges are to provide sufficient good jobs for a relatively young workforce in a context of global ageing, and putting in place the conditions for the current young generations to have adequate retirement income when they reach old age.

Figure 2. Old-age dependency ratios are projected to at least double in most G20 countries

Number of people older than 65 years per 100 people of working-age (20-64)

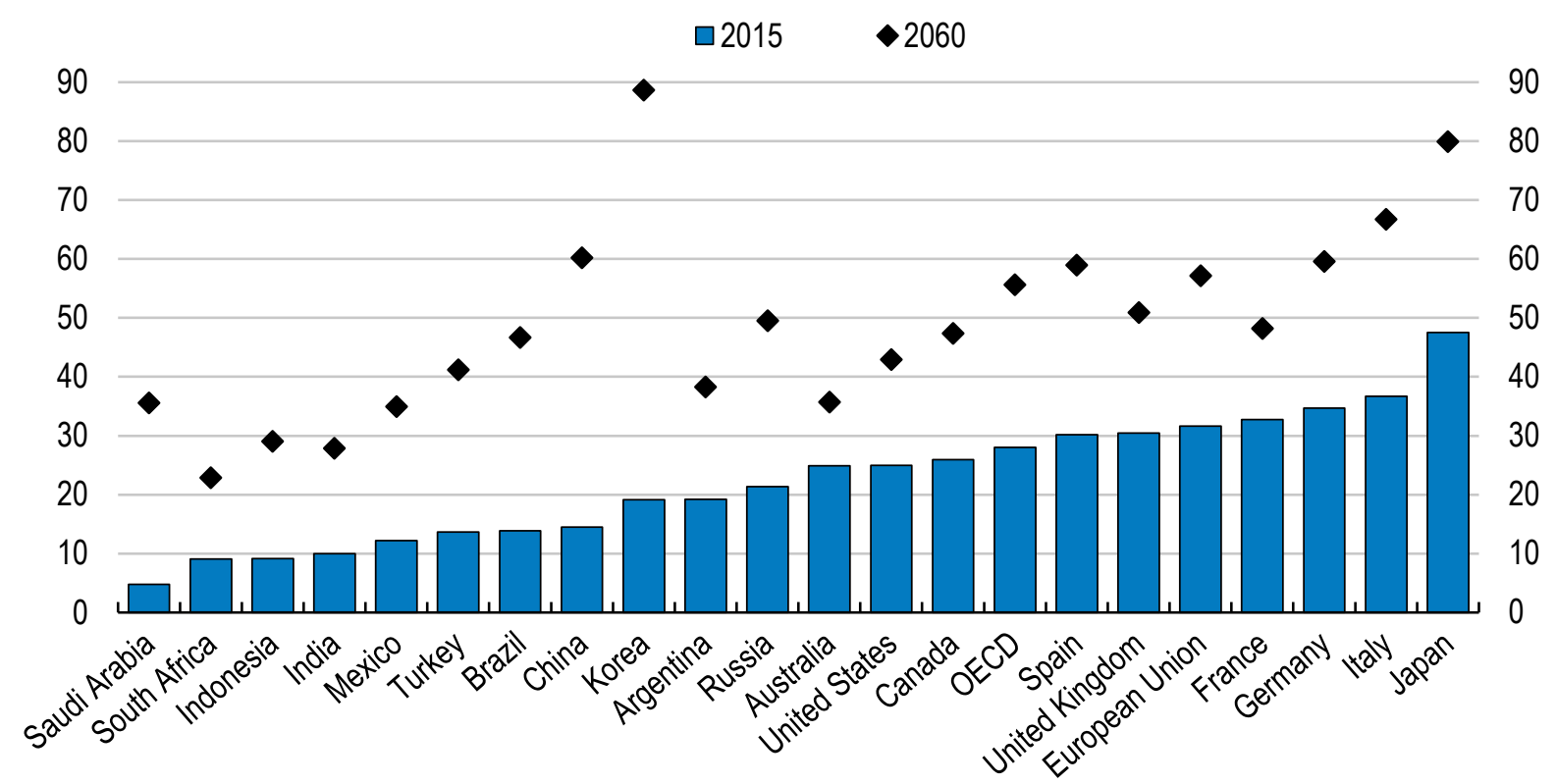

Source: National sources for Argentina, Australia, Brazil, Canada, Germany, Indonesia, Italy, Japan, Korea, Mexico, Russia, Spain, Turkey, the United Kingdom and the United States; Eurostat Population Projections (2008 revision) for France and the European Union; and UN World Population Prospects, 1950-2050 (The 2017 Revision) for China, India, Saudi Arabia and South Africa.

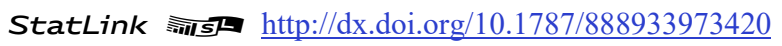

8. The share of the population aged 80 years and more will rise even more dramatically, almost tripling globally between 2015 and 2060 (Figure 3). In Japan, the share of people over 80 is expected to rise from $8 \%$ in 2015 to $18 \%$ by 2060 , and in Korea from $3 \%$ to $17 \%$. Although the impact of "old ageing" will depend on the extent to which the health status of the elderly at a given age improves over time, it is likely to raise demands on health and care systems to address dependency.

9. Within countries, population ageing is not a uniform process. Evidence from both advanced and emerging economies shows that highly educated and wealthier individuals have greater chances of living longer (OECD, $\left.2017_{[1]}\right)$. On average across OECD countries, a 25year old university-educated man can expect to live 7.5 years longer than his low-educated peer. Furthermore, urban centres draw younger and more mobile workers while rural areas are often already much older, with larger shares of retirees and fewer younger workers to support them. Policies put in place to deal with the aggregate impacts of ageing will therefore need to consider their unequal effects on people and regions. 
Figure 3. The share of the elderly will rise dramatically

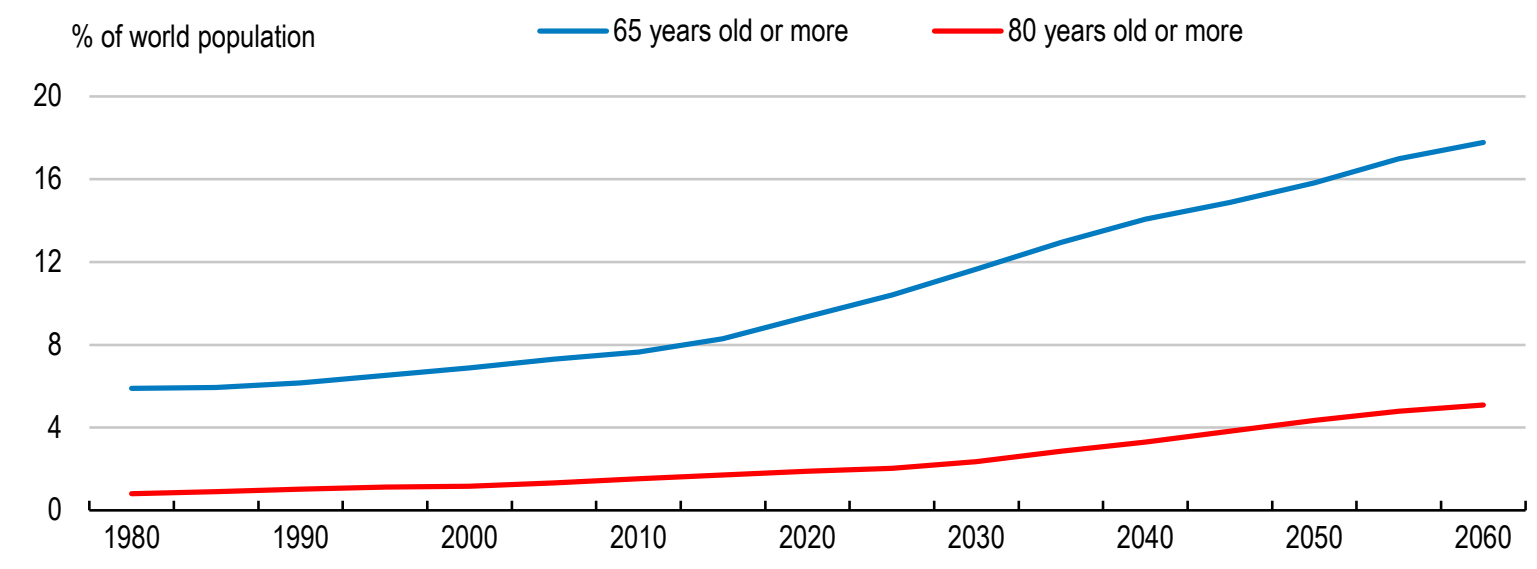

Source: United Nations World Population Prospects: The 2017 Revision.

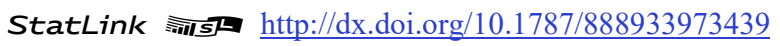

\subsection{Ageing is affecting the prospects for growth and inclusiveness}

10. Demographic change is already affecting macroeconomic outcomes in a number of economies. However, the magnitude of its effects on growth and inequality in the coming decades remains uncertain. It will be influenced by the depth and speed of ageing in each country and the adjustment of relative prices and behaviours. Ultimately, the impact of ageing on income growth will depend on the relative magnitudes of (i) declining employment to population ratios, (ii) rising capital per worker, and (iii) productivity growth which in turn depends on the pace of innovation, technology adoption and human capital investments induced by ageing. In open economies, per capita income will also be influenced by net returns on foreign investment. The balance of these effects is subject to a debate that is far from settled to date, and will hinge on the policy actions taken nationally and globally.

\subsubsection{Changes in population growth and the age structure of the population will weigh on GDP per capita growth}

11. The slowing growth of working-age populations will exert pressure on potential growth of GDP per capita, and may lead to durably slower increases in living standards if policies do not adjust rapidly enough. Assuming no changes in institutional and policy settings, the declining share of the working-age population in total population is projected to have a negative contribution to global trend GDP per capita growth from 2040 onwards, exacerbating the slowdown in potential growth driven in part by EME convergence to lower longterm productivity growth (Figure 4). Over the period 2018-30, declining working-age populations will drag down GDP per capita growth in 11, mostly advanced, G20 countries, by up to 0.5 percentage points. Over the period 2030-60, only India and South Africa will still enjoy a demographic dividend (Figure 5). 
Figure 4. Ageing will weigh on global real GDP per capita growth

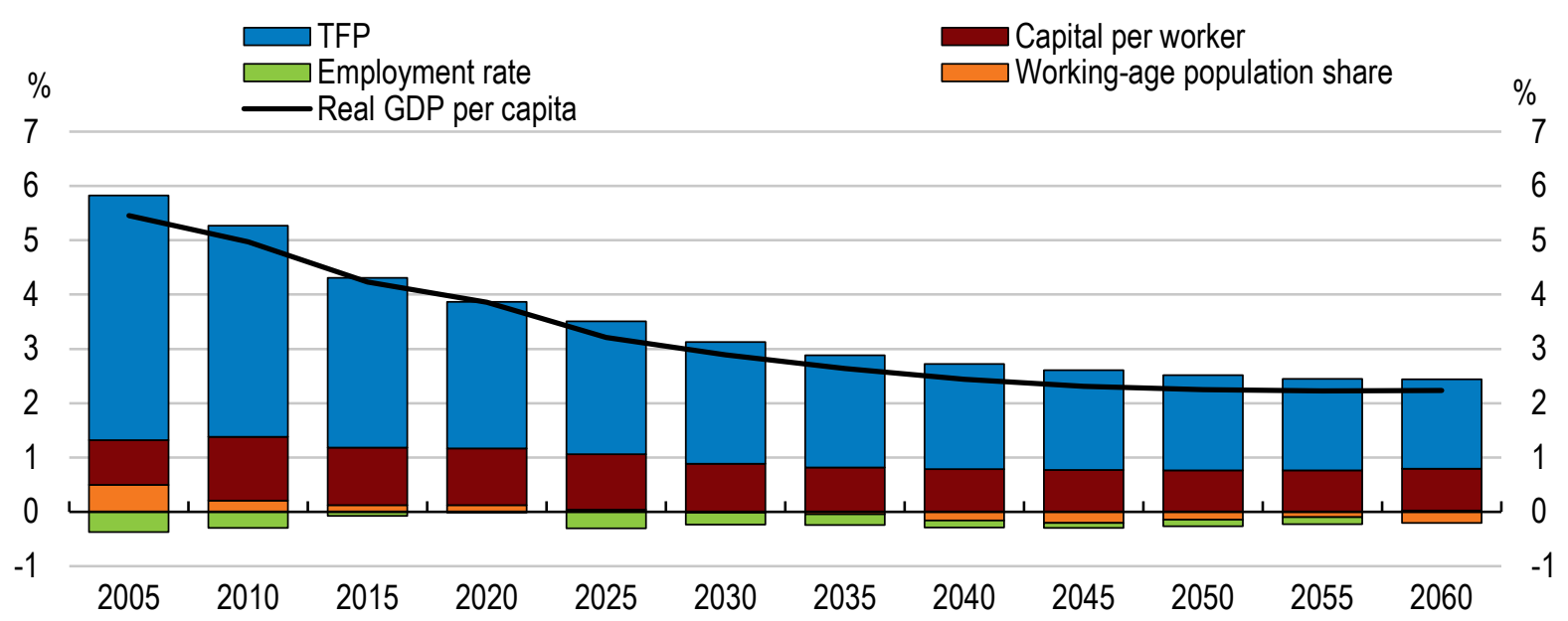

Note: "Global" refers to an aggregate of 46 countries, which today account for $82 \%$ of world output measured at purchasing power parities. Working-age population is defined as people aged 15 to 74 over the projection period.

Source: Guillemette and Turner (2018[2]).

StatLink 제대 http://dx.doi.org/10.1787/888933973458

Figure 5 Ageing will weigh on living standards in most G20 countries

Working-age population contribution to annual GDP per capita growth

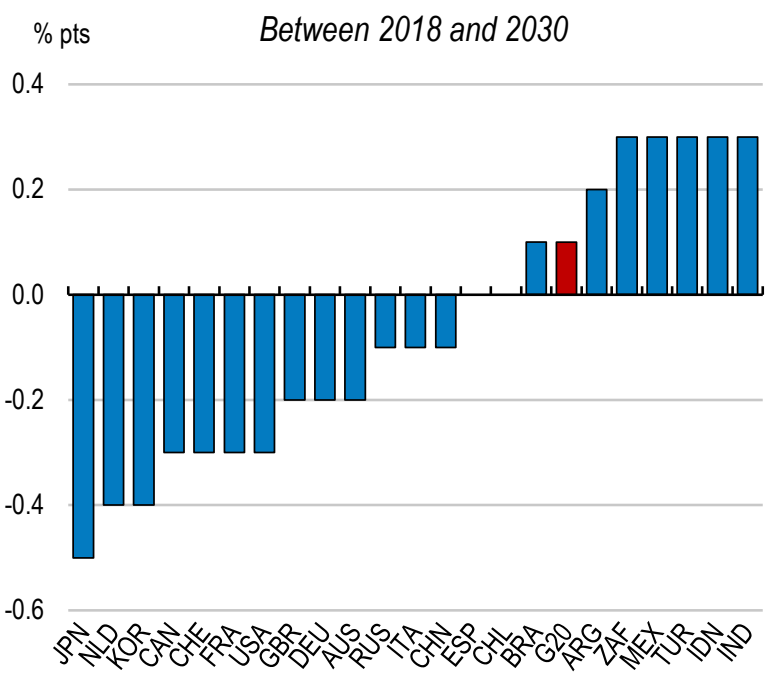

$\begin{array}{cc}\% \text { pts } & \text { Between } 2030 \text { and } 2060 \\ 0.4 & \end{array}$

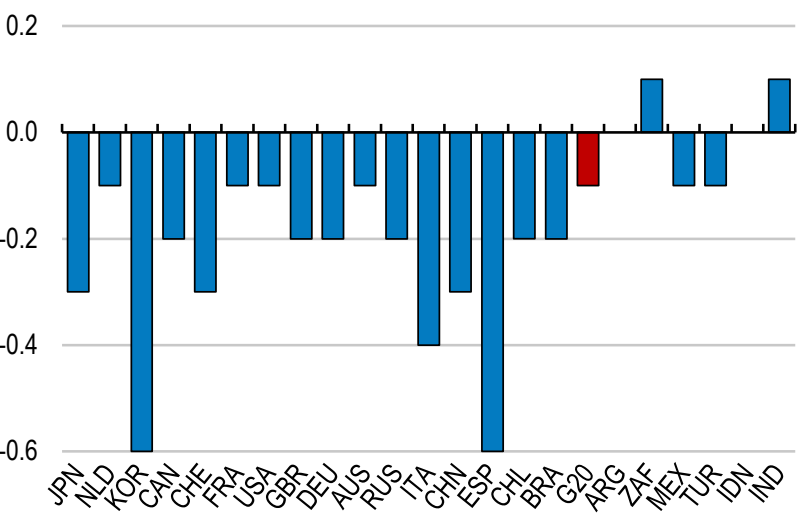

Source: Guillemette and Turner (2018[2]).

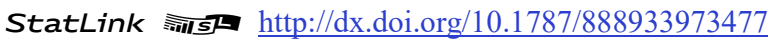

12. Ageing also drives down aggregate employment rates given that employment rates tend to decline with age. Employment rates of older people have risen significantly over the past two decades, with particularly strong gains for women. In the OECD, the employment rate of people aged 55 to 64 grew from $47.8 \%$ in 2000 to $61.4 \%$ in 2018 (Figure 6), while it only increased slightly from $75.9 \%$ to $78.48 \%$ for $25-54$ year-olds. Senior employment has made significant progress in Germany, Italy, France and Australia. It has also been increasing markedly 
in Russia, but appears to have largely stagnated over the same period in other G20 emerging economies. Notwithstanding these overall positive developments, there remains scope to increase senior employment, particularly by narrowing socio-economic and gender gaps. Less educated people over 55 have low employment rates. They are more likely to retire when they reach the retirement age than their highly-educated peers, and less likely to find work if they remain active (Figure 7). In addition, older women work less than men in most countries, and the gender gap in employment is even more pronounced at lower levels of education attainment.

Figure 6. Employment rates at age 55-64 have increased since 2000 in most economies

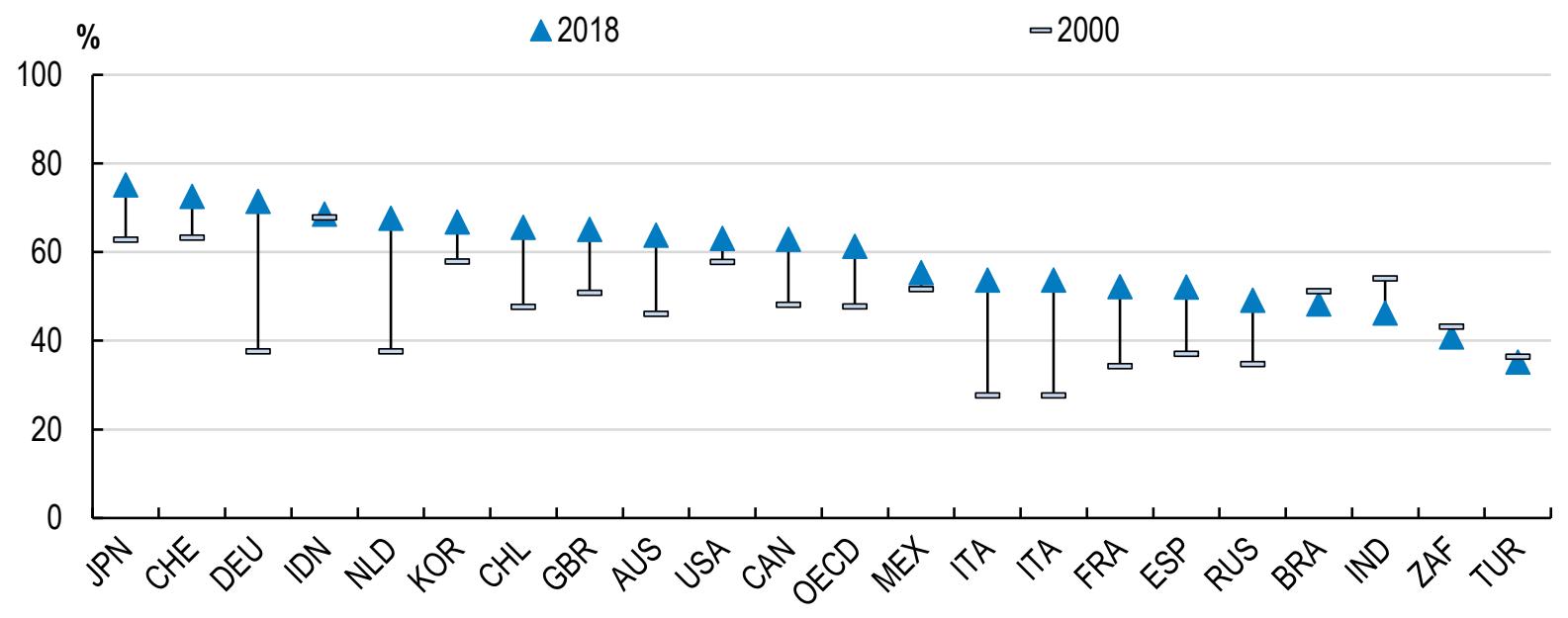

Source: OECD Labour Force Statistics database.

StatLink त्ञा5 http://dx.doi.org/10.1787/888933973496

Figure 7. Gaps in employment rates at age 55-64 by education persist

$\%$ of population aged 55 to 64,2017 or latest year available

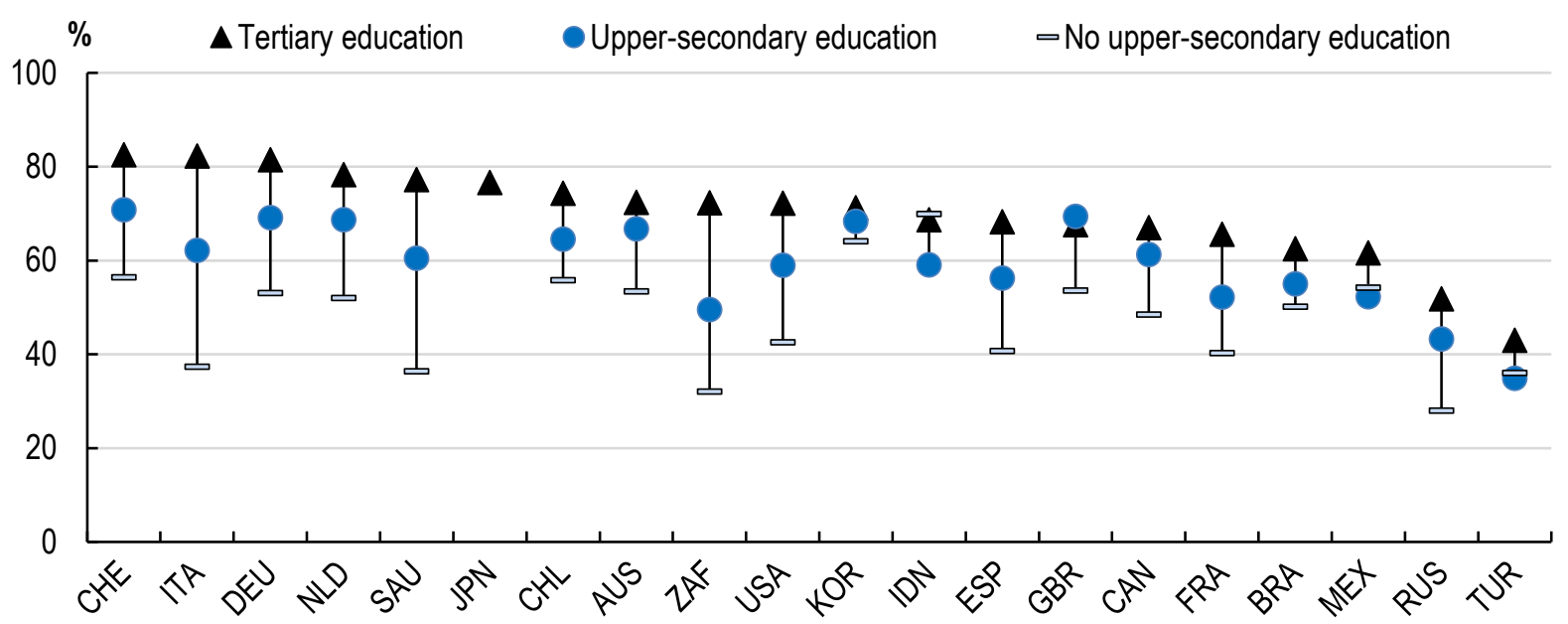

Note: Data on upper-secondary education or below are not available for Japan.

Source: Calculations from the OECD Education Database.

StatLink 제애 http://dx.doi.org/10.1787/888933973515 


\subsubsection{Will investment slow down?}

13. Demographic developments affect aggregate investment via different channels. As demographic change reduces the ratio of working-age to total population, the price of labour relative to physical capital is expected to rise, leading firms to increase capital per worker. This effect would be exacerbated if ageing induces higher saving rates, thus exerting further downward pressure on neutral interest rates (see Box 1). Talent shortages should incentivise firms to invest in labour-saving technologies such as robotics and artificial intelligence. There is evidence that countries (e.g. Germany, Korea) undergoing a more rapid ageing of their workforces have experienced a faster development and adoption of automation technologies since the 1990s (Acemoglu and Restrepo, 2017 $[3]$; 2018 $8_{[4]}$; Abeliansky and Prettner, $\left.2017_{[5]}\right)$. The capital intensity of production should keep increasing in rapidly ageing countries and in industries with high potential for automation.

14. However, the rate of total capital accumulation could still slow down despite higher capital per worker, due to shrinking or more slowly growing labour forces. In addition, capital investments that are complementary to workers, rather than labour-saving, could be cut as scarcer labour reduces their marginal return. Slower expected aggregate demand growth as total population growth slows down, as well as the relative expansion of labour-intensive services in high demand by the elderly that are not easily amenable to automation such as health and personal care, could also weigh on aggregate investment. The literature indeed indicates that ageing is likely to push down aggregate investment demand (Lee, 2016 $[6]$; Goodhart and Pradhan, $2017_{[7]}$; Aksoy et al., $\left.2019_{[8]}\right)$.

15. While ageing of the world's population is expected to result overall in higher capital per worker, higher wages and lower marginal returns to capital, not all countries are experiencing demographic change at the same time and speed. In open economies with mobile capital, global rather than national ageing should determine the extent to which factor prices and capital deepening adjust. Countries ageing faster than the rest of the world, such as Japan and many European economies, tend to invest more abroad, which may partially offset the expected decline in returns to capital. Conversely, younger developing countries would experience capital inflows and a larger decline in marginal rates of return than warranted by domestic conditions alone. Migration can have a similar, though likely smaller, offsetting effect. In 2017, migrants accounted for $3.5 \%$ of the G20 population (OECD/ILO/IOM/UNHCR, 2018 ${ }_{[9]}$ ). 


\section{Box 1. Demographics and interest rates: Is ageing a driver of "secular stagnation"?}

Demographic change has been argued to be one of the structural factors helping explain the long-term decline in real interest rates. While retirees, who tend to consume a higher proportion of their income, will account for a larger share of total populations over time, the expectation by working-age households that they will spend more years in retirement with possibly less generous pension support pushes up their saving rates. Overall, uncertainty is high about the effects on the savings-investment balance, and thus on real interest rates, of the retirement of baby-boomers, increasing longevity and declining fertility given the range of large but offsetting effects.

The life-cycle hypothesis suggests that people take into account their future income to smooth consumption over time. This implies that the working-age population tends to save a large share of their income while retirees use their savings to sustain consumption. As the population ages, in particular the baby-boom generation (Gagnon, Johannsen and Lopez-Salido, $\left.2016_{[10]}\right)$, a rising share of older people in the total population could lead to lower savings, which might exert upward pressure on real interest rates.

At the same time, rising life expectancy encourages households to save more to finance consumption during longer retirements (Ikeda and Saito, 2014 ${ }_{[11]}$; Gagnon, Johannsen and Lopez-Salido, 2016 ${ }_{[10]}$; Carvalho, Ferrero and Nechio, 2016 ${ }_{[12]}$; Lisack, Sajedi and Thwaites, 2017 $[13]$; Rawdanowicz, Hammouch and Kasai, 2017 [14]). These higher savings, for given investment behaviours, tend to drive down the real interest rate. The incentive to save might be stronger, and therefore the effects on interest rates larger, when households believe that public pension systems will not be able to cope with the additional burden generated by an ageing population (Carvalho, Ferrero and Nechio, 2016 $6_{[12]}$ ).

In addition, declining fertility rates and therefore slower population growth could eventually reduce the size of the labour force and, as a result, lead to higher capital-labour ratios. This in turn may put downward pressure on the marginal product of capital and real interest rates.

Demographics are also likely to affect productivity. Older workers or retirees might not be able to innovate as much as middle-aged workers. Empirical evidence shows that the production of patents is lower when the population is older across the OECD economies (Aksoy et al., 2019 ${ }_{[8]}$ ). Thus, ageing may result in lower rates of innovation and hence productivity, which could reduce the rate of return of capital and result in lower interest rates.

Recent empirical evidence attempts to quantify these influences of demographic change on real interest rates. For instance, in the United States, demographic factors, such as increased life expectancy and declining fertility rates, appear to have lowered the interest rate since 1980 by 11/4-percentage points (Gagnon, Johannsen and Lopez-Salido, 2016 ${ }_{[10]}$ ). A similar effect is found for Japan (Ikeda and Saito, 2014 $\left.{ }_{[11]}\right)$. More generally, in the advanced economies, ageing could have reduced interest rates between $3 / 4$ (Lisack, Sajedi and Thwaites, 2017 $[13]$ )and 11/2 percentage points (Carvalho, Ferrero and Nechio, 2016 ${ }_{[12]}$ ). Looking forward, the effect of demographics on interest rates is not expected to reverse as the baby-boom generation retires (Gagnon, Johannsen and Lopez-Salido, 2016 ${ }_{[10]}$; Lisack, Sajedi and Thwaites, $2017_{[13]}$. However, empirical time-series analysis suggests that this effect might be more muted, depending on the country or the metric used (Rawdanowicz, Hammouch and Kasai, 2017 $[14])$. 


\subsubsection{The effect of ageing on productivity and incomes is uncertain}

16. There are concerns that population ageing has been one of the forces behind the "productivity slowdown", and may continue to weigh on labour productivity growth in decades to come through several channels. First, the age profile of employment will continue shifting towards older workers whose skills are more at risk of becoming obsolete as digitalisation transforms labour market needs. Evidence from the OECD Survey of Adult Skills confirms that older workers score lower on literacy and numeracy proficiency than younger adults, reflecting both lower initial education and age-related declines (Paccagnella, 2016 $\left.{ }_{[15]}\right)$. Part of this gap could however fade away as future cohorts of older workers are likely to be better accustomed to working with digital technologies than current ones. Second, an older labour force may be less entrepreneurial, less creative and less innovative than a younger one (Liang et al., $2014_{[16]}$ ), though evidence is mixed in this regard. Third, a larger share of elderly population will shift the structure of consumption, and therefore of production, towards lower-productivity services such as personal care. These composition effects may reduce aggregate productivity growth.

17. However, the impact of demographics on productivity does not have to be dire. Older workers' accumulated experience in knowledge-based jobs may compensate for the loss of productivity in more repetitive work, especially as they take on more supervisory roles. Rising longevity has also been accompanied by an increase in years in good health. Since 2000, $85 \%$ of the gains in life expectancy at birth in OECD countries are estimated to have been spent in good health, free of disability (OECD, 2017 $\left.{ }_{[17]}\right)$. Better health of older workers may counteract the effect of ageing on productivity. Furthermore, as mentioned above, ageing holds potential to spur increased R\&D to find technology solutions to labour shortages, as well as to respond to the needs of older individuals, including in health-related technology and robotics. ${ }^{2}$

\subsubsection{Intra- and inter-generational inequalities could be exacerbated}

18. Demographic changes, combined with rising inequality trends and tight public finance constraints in many countries, are modifying life prospects at older ages. While the current generation of older people is experiencing higher incomes and lower poverty risks than previous ones in most countries, the younger generations are likely to face again higher inequality in old age. They are expected to live longer, but have been experiencing more unstable labour market conditions and widening inequalities in the distribution of earnings and household income. Moreover, many advanced countries have already lowered pension promises as a response to population ageing.

19. Within generations, concerns about inequality in old age arise from the fact that disadvantages tend to accumulate over the life course. Inequalities in education, health, employment and earnings reinforce each other and evolve over the life course. Children born into poorer families are more likely to experience poor health and worse learning outcomes, and are less likely to attain higher education degrees and succeed in the labour market (OECD, 2017 $\left.{ }_{[1]}\right)$. In turn, people with low quality jobs, unstable careers and lower incomes tend to have less access to health services, and are less likely to retire with adequate income from pension systems and

\footnotetext{
${ }^{2}$ Outcomes may diverge across industries, those more amenable to automation being better prepared to cope with the impacts of ageing (Acemoglu and Restrepo, 2018 ${ }_{[4]}$ ). The ability of economies to offset the consequences of declining employment ratios through investment may also depend on other long-term macroeconomic developments, notably whether the constraint of the zero lower bound becomes frequent and prevents the downward adjustment of real interest rates necessary for capital deepening (Eggertsson, Lancastre and Summers, 2018 [94]), and on the responsiveness of investment to changes in interest rates.
} 
private asset accumulation. Pensions tend to attenuate income inequality among older households with coverage but, on average across OECD countries, about two-thirds of lifetime earnings inequality is transmitted to pension inequality (Figure 8). Moreover, the shorter life expectancy of low-educated people lowers the value of their cumulated pension earnings by $13 \%$ relative to highly educated retirees (OECD, 2017 $\left.{ }_{[1]}\right)$. Low-income retirees in many countries are also unlikely to be able to afford long-term care (LTC) in their own homes, even in the presence of means-tested social protection for LTC needs (Muir, $2017_{[18]}$ ).

Figure 8. Increases in wage inequality increase pension inequality

Change in the Gini index of pensions for a 1 percentage point increase in the Gini index of wages

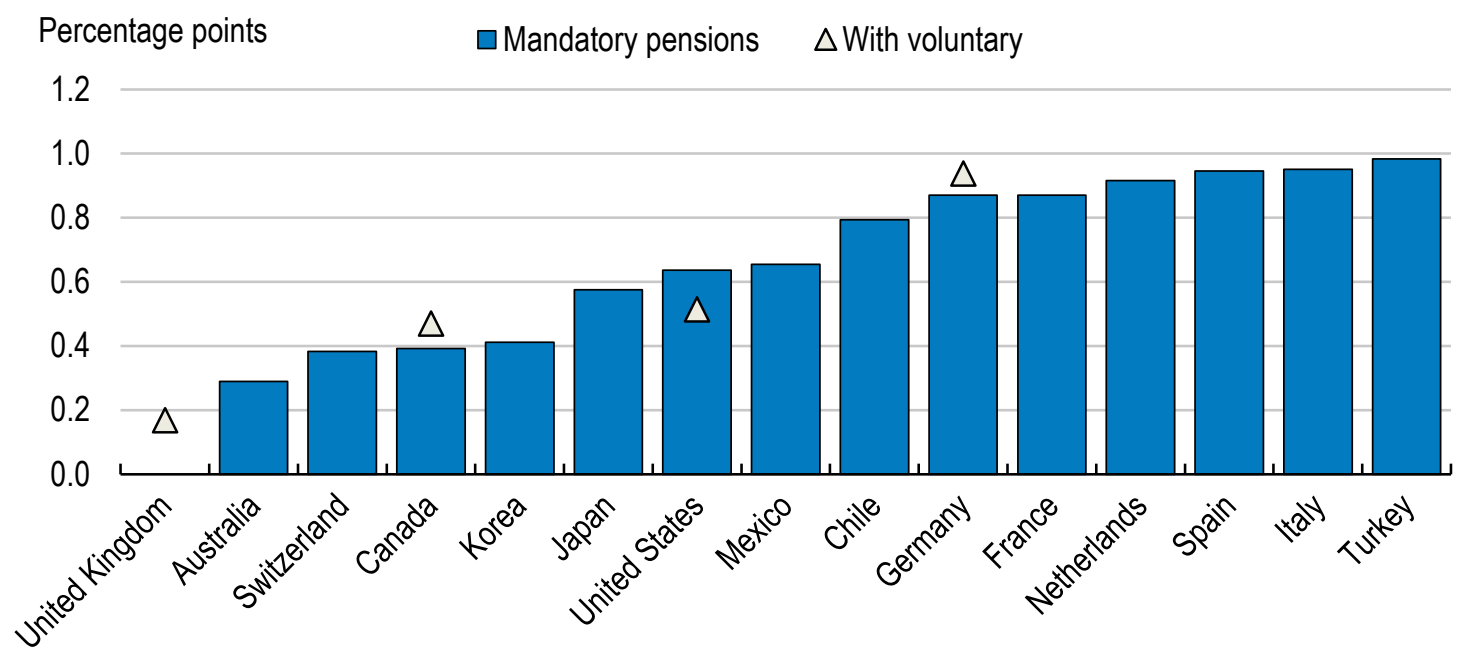

Note: The figure refers to gross (i.e. pre-tax) wages and pension benefits. There is no change in the Gini coefficient of pension benefits from mandatory schemes in the United Kingdom, as it provides only basic pensions and social assistance payments which do not change with the level of individual wages.

Source: Computations based on the OECD pension model (OECD, 2017[1]).

StatLink त्ञाज़ http://dx.doi.org/10.1787/888933973534

20. The adjustment of both policy settings and asset markets to ageing raise issues of equity between generations. Older people have seen their relative income rise over time in OECD countries, where the income of people aged 60-64 grew on average by a cumulative $13 \%$ more than that of people aged 30-34 since the mid-1980s (OECD, 2017 $\left.{ }_{[1]}\right)$. In pay-as-you-go pension systems, pension incomes for an increasing population of retirees have been maintained in part by raising contributions on working-age households, thereby weighing on their disposable incomes. The continuation of demographic trends could exacerbate inter-generational inequality if pension pay-outs are preserved by increasing the burden on current workers.

21. Furthermore, older people tend to be the primary holders of wealth, particularly housing wealth. As one of the largest spending items in household budgets and one of the largest assets in household portfolios, housing is a fundamental driver of the accumulation, distribution and transmission of wealth. Ageing is likely to increase the prevalence of single-occupant dwellings and raise the demand for housing in urban centres in close proximity to public transportation and health facilities. The pressures on already high housing prices in some urban areas could price younger households out of house ownership, or add to their debt service burdens and financial vulnerability. 
22. At the same time, the poverty risk is higher for people above $\mathbf{7 5}$ years than for any other age category. On average and across OECD countries, people aged 66-75 have lower incidence of poverty than the whole population, but those over 75 are most exposed to poverty risk (Figure 9a). One explanation is that people currently above 75 entered retirement with lower starting pension benefits than successive cohorts, as real earnings have tended to grow over time. While these cohort effects may reduce the incidence of poverty among the elderly in the near term, growing disparities in labour market outcomes of today's younger generations may result in higher pensioner poverty in the future. Another important factor is the higher share of women among people over 75 , given the gender difference in old-age poverty, reflecting past employment and wage gaps (Figure 9b). Across countries, the generosity of minimum/basic pensions and survivor pensions influences the incidence of old-age poverty. More generally, reforms in the areas of social security and private financing of old age will need to take into account effects on poverty and inequality.

Figure 9. The poverty risk is highest above 75, especially for women
a. Poverty risk by age
b. Poverty risk by gender
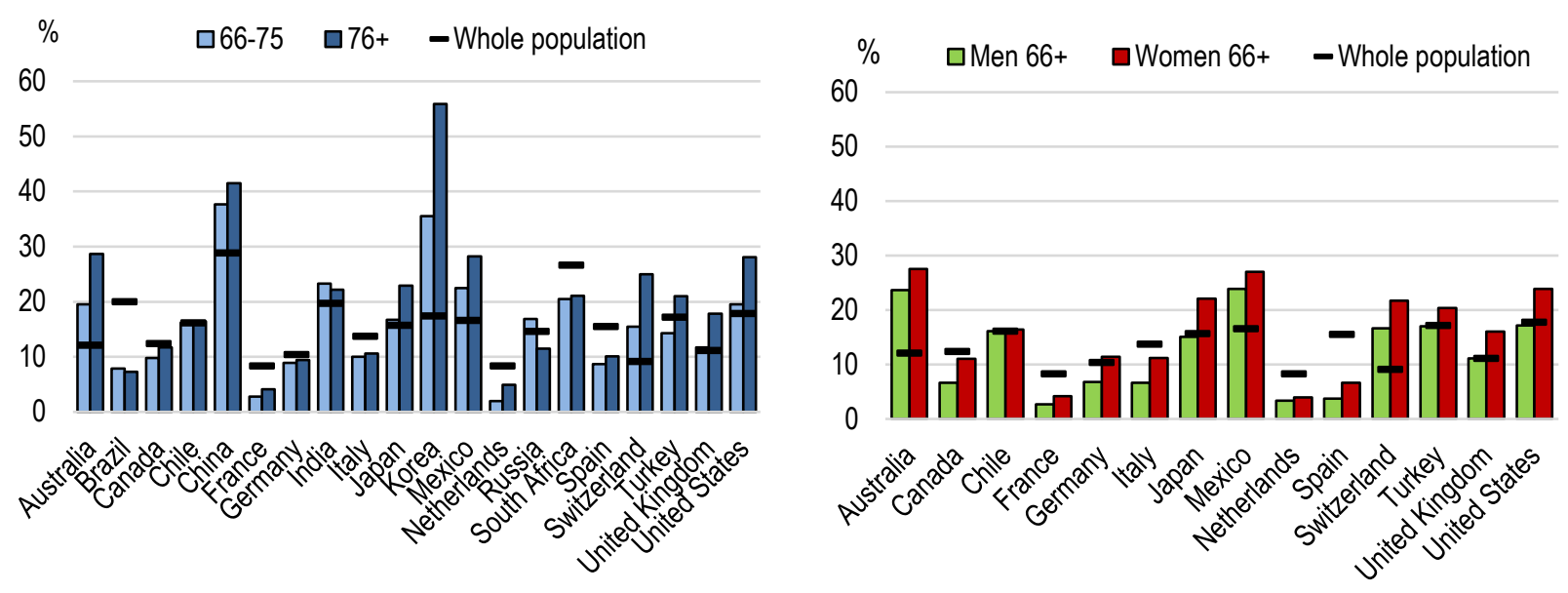

Note: Latest year available. Poverty is defined as having incomes below $50 \%$ of median equivalised household disposable income, after taxes and transfers.

Source: OECD Income Distribution database.

StatLink त्ञाज http://dx.doi.org/10.1787/888933973553

\section{Ageing creates deep pressures on fiscal sustainability}

23. The structure of pension systems, as well as their contributions to income at old age, vary considerably across countries (Figure 10; Annex Table 3). The contribution of public transfers (pensions plus other benefits) to the total income of older households ranges from less than $8 \%$ in Mexico to more than three quarters in France. Work-related earnings account for more than half of old-age income in Korea and Mexico and more than a third in the United States and Japan, but much less in European countries. Shrinking workforces will create particular pressures on countries where older households are more reliant on public sources to sustain their living standards, while a low return environment will be particularly challenging where private asset accumulation play a larger role. 
Figure 10. Income sources of people over 65

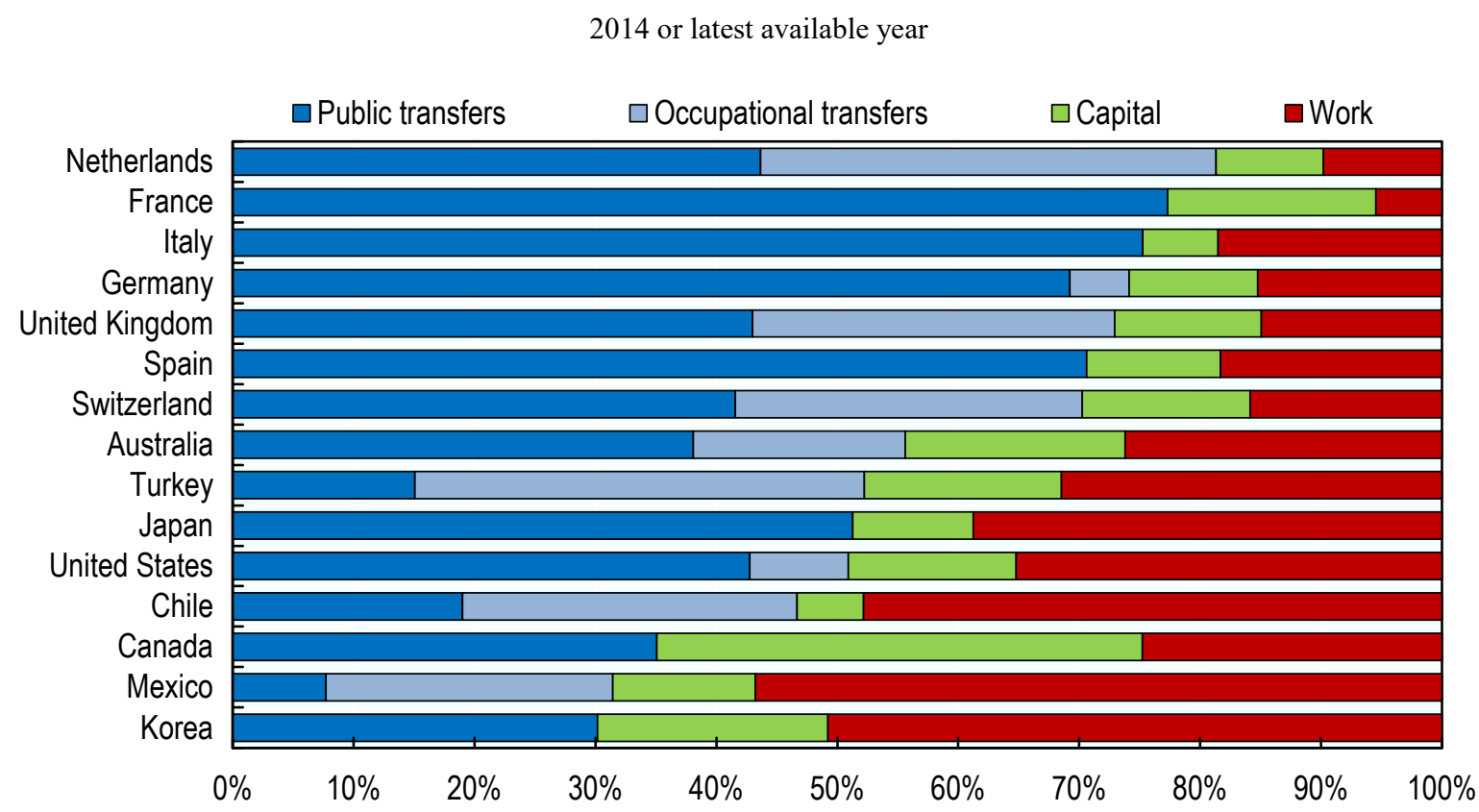

Note: Public transfers include earnings-related pensions and resource-tested benefits. Occupational transfers are transfers received from employment-related social insurance schemes. Income from work includes both earnings (employment income) and income from self-employment. Capital income includes private pensions as well as income from the returns on non-pension savings. The data shown are for disposable incomes (i.e., net of personal income tax and social security contributions), measured on a household basis and adjusted for differences in household size.

Source: OECD (2017 $[17])$, based on the OECD Income Distribution database.

StatLink त्ञाज http://dx.doi.org/10.1787/888933973572

\subsection{Sustainability of unfunded public pensions and social security systems}

24. Population ageing will put unprecedented stress on public finances to finance pension, health and long-term care expenditures. The ageing-related stress comes first and foremost from two drivers: the pace of increase in dependency ratios, and the declining growth in potential GDP and wages. Countries with publicly financed pay-as-you-go (PAYG) pension, health and long- term care schemes may require adjusting spending or raising additional revenues to ensure long-term sustainability, given that current revenues from taxes and social security contributions levied on a shrinking share of working-age people will need to finance current benefits to a rising share of retirees. The capacity of pension and health systems to meet their promises might be further endangered by faster than anticipated ageing, given the large degree of uncertainty surrounding demographic projections, or by negative economic shocks (Fall et al., $\left.2014_{[19]}\right)$.

\subsubsection{Public pension costs}

25. Public expenditure on pensions as a share of GDP varies widely among G20 countries and is highest in continental European countries and Japan (Figure 11). This range reflects different demographic profiles, but also differences in the coverage of pension benefits and importance of private pensions (e.g. compulsory occupational schemes). Public pension 
expenditures have risen by about 1.7 percentage points of GDP on average since 2000 in G20 countries, with Turkey and Japan recording the strongest increases.

26. Demographic change will be the main driver of public pension expenditure in the future. Past pension reforms have helped contain future pressures on pension expenditure. ${ }^{3}$ Nevertheless, it is projected to increase in the majority of G20 countries by 2050/60 (Table 1). The projected increase is particularly pronounced in several emerging G20 countries such as Brazil, China and Saudi Arabia, but from a low share of GDP.

Figure 11. Public expenditures on pensions

Public gross expenditure on cash and non-cash benefits for old-age and survivors as a share of GDP

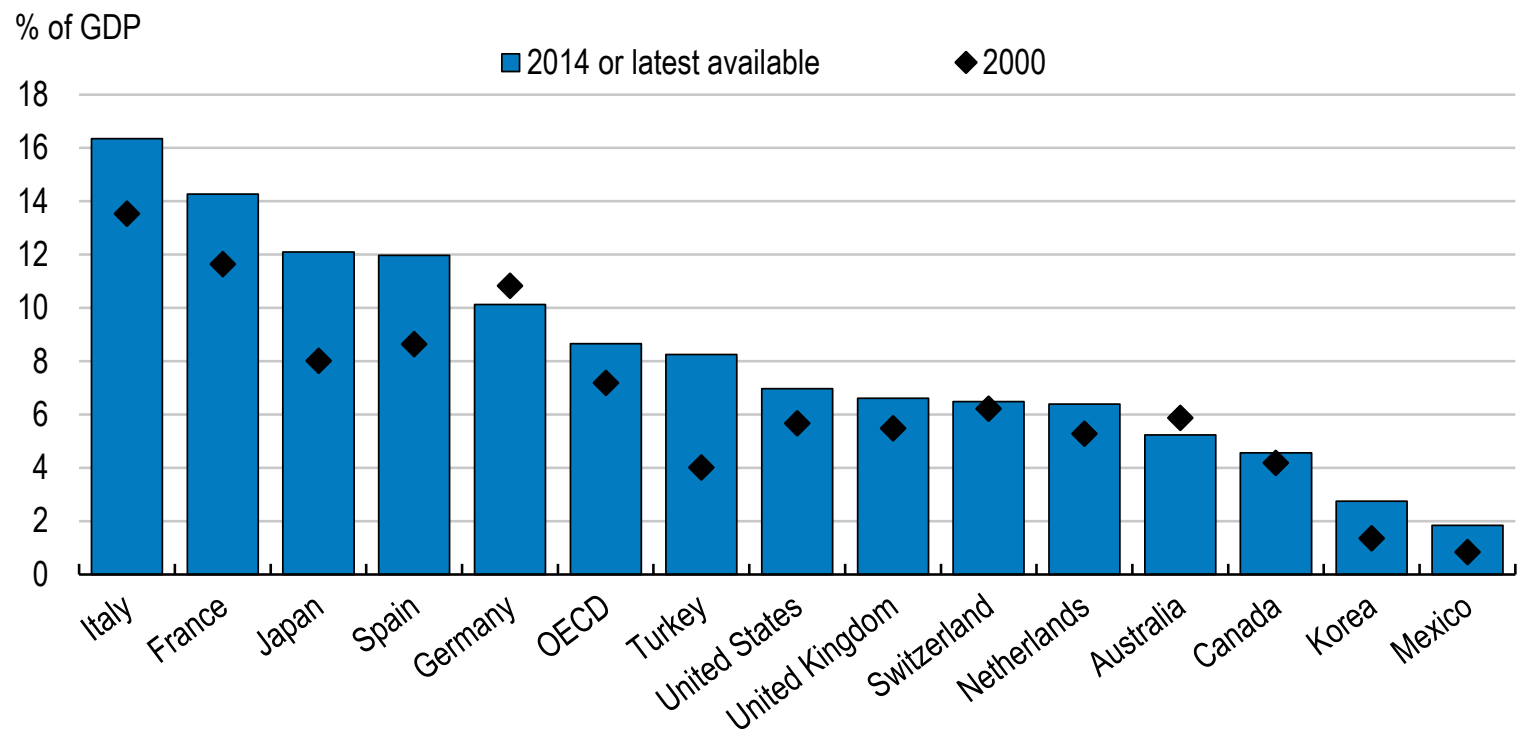

Source: OECD Social Expenditures Database (SOCX).

StatLink :

3 See below and Annex Table 5, where recent pension reforms in G20 economies since around 2010 are described. 
Table 1. Projections of public expenditure on pensions, 2013-2060, \% of GDP

\begin{tabular}{|c|c|c|c|c|c|c|c|}
\hline Country & $2013-2015$ & 2020 & 2030 & 2040 & 2050 & 2055 & 2060 \\
\hline Argentina & 7.8 & & & & 10.4 & & \\
\hline Australia & 4.0 & & & & & 3.7 & \\
\hline Brazil & 9.1 & & & & 16.8 & & \\
\hline Canada & 5.5 & & & & 6.9 & & \\
\hline Chile & 5.1 & & & & 4.2 & & \\
\hline China & 4.1 & & & & 9.5 & & \\
\hline France & 14.9 & 14.6 & 14.7 & 13.8 & 12.8 & 12.3 & 12.1 \\
\hline Germany & 10.0 & 10.3 & 11.6 & 12.2 & 12.5 & 12.6 & 12.7 \\
\hline India & 1.0 & & & & 1.0 & & \\
\hline Indonesia & 0.8 & & & & 1.2 & & \\
\hline Italy & 15.7 & 15.3 & 15.7 & 15.8 & 14.8 & 14.2 & 13.8 \\
\hline Japan & 10.2 & & & & 9.5 & & \\
\hline Korea & 2.6 & & & & 6.3 & & \\
\hline Mexico & 1.8 & & & & 3.0 & & \\
\hline Netherlands & 6.9 & 7.1 & 7.7 & 8.3 & 8.1 & 7.9 & 7.8 \\
\hline $\begin{array}{l}\text { Russian } \\
\text { Federation }\end{array}$ & 9.1 & & & & 12.4 & & \\
\hline Saudi Arabia & 2.7 & & & & 9.4 & & \\
\hline South Africa & 2.2 & & & & 3.3 & & \\
\hline Spain & 11.8 & 11.8 & 11.2 & 11.9 & 12.3 & 11.4 & 11.0 \\
\hline Switzerland & 9.8 & & & & 10.7 & & \\
\hline Turkey & 7.2 & & & & 5.6 & & \\
\hline United Kingdom & 7.7 & 7.4 & 7.9 & 8.4 & 8.1 & 8.3 & 8.4 \\
\hline United States & 4.9 & & & & 5.9 & & \\
\hline
\end{tabular}

Note: Pension schemes for civil servants and other public sector workers are generally included in the calculations for EU member states: see European Commission (2018[20]). Figures based on baseline scenarios, which assume no further policy changes in the projection period. Announced but not yet legislated changes are not reflected.

Source: European Commission (2018[20]); OECD (2017[17]); Standard and Poor's (2013 [21]; 2016[22]).

\subsubsection{Health care costs}

27. Public health expenditures amounted to 7\% of GDP on average across advanced G20 economies in 2017, up from 5.5\% in 2000, and 2.9\% in emerging G20 economies in 2015, up from $2.1 \%$ in 2000 (Figure 12). Japan, the United Kingdom and the United States experienced the fastest increases in public health expenditure as a share of GDP.

Most studies find only a limited effect of demographics on the past growth of health expenditure compared to non-demographic effects. Health expenditures are relatively high for young children; they decrease and remain stable for most of the prime-age period, and then start to increase rapidly in older age. What matters most for health care expenditures are the death-related costs, as costs for people in their last year of life are between 2 and 15 times higher than for survivors of similar age. The impact of ageing on increased health expenditure, then, is predominantly determined by the share of a country's population being close to death (Marino et al., 2017 [23]). Rapidly ageing populations have also affected spending on health care through patterns of morbidity. With increases in longevity, health-related costs are therefore progressively shifted to older ages. For example, while in $201060 \%$ of health care expenditures were directed to people below 65 years old, roughly the same percentage will be directed to people above 65 in 2060 (De La Maisonneuve and Oliveira Martins, 2015 [24]). The extent to which ageing will play a larger role in future health 
spending than it did in the past depends largely on whether longevity gains will translate into additional years in good health without disabilities.

Figure 12. Public health expenditures

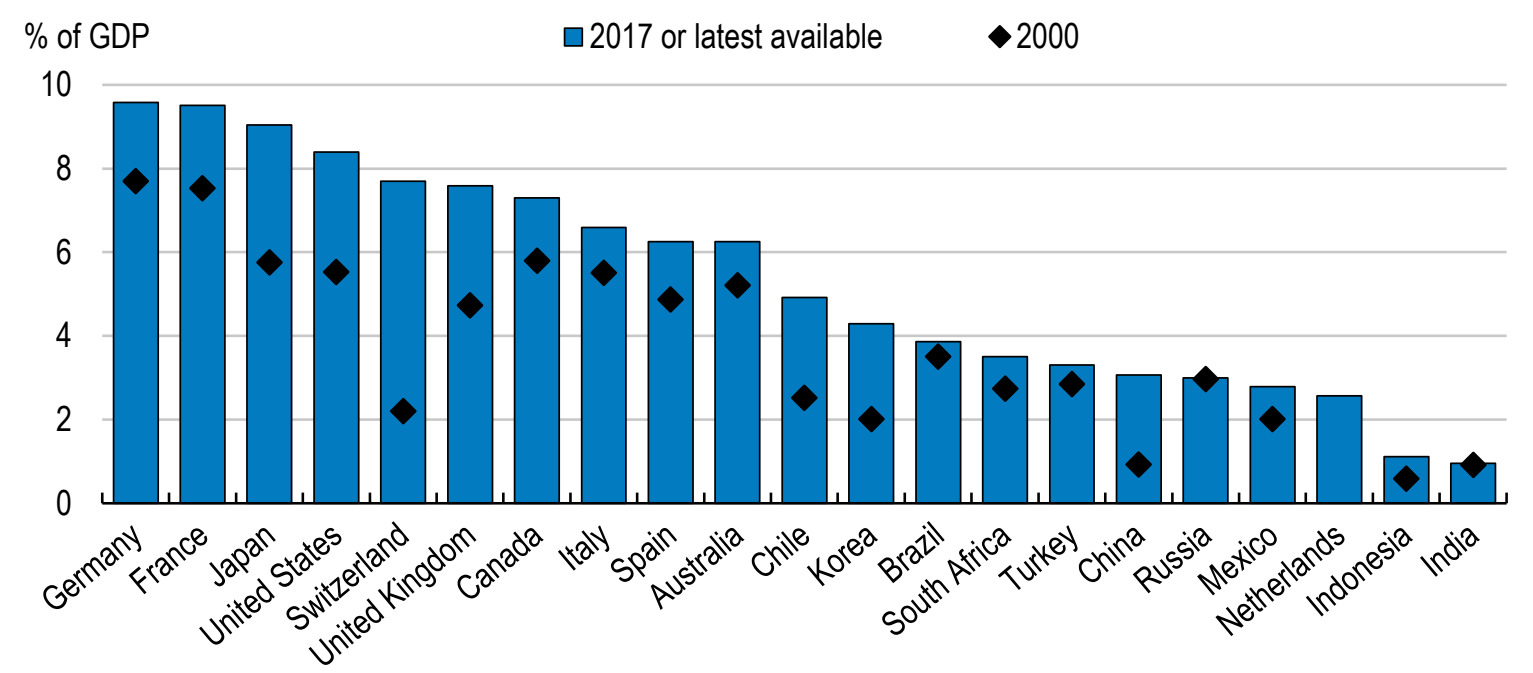

Note: Public health expenditures include health expenditures through government schemes and social health insurance schemes.

Source: OECD Health Statistics 2017, WHO Global Health Expenditure Database.

StatLink त्ञाज http://dx.doi.org/10.1787/888933973610

28. Non-demographic factors are generally found to be the main drivers of growth in health care expenditure (Marino et al., 2017 [23]; De la Maisonneuve et al., 2016 [25]; Lorenzoni et al., 2019 [26]). Changes in incomes and the associated demand for higher quality services have been the main reason behind increases in health spending in the past decades. Productivity gains, whilst achievable, are made more challenging by the labour-intensive nature of the health care sector. Technological progress helps extend the scope, range and quality of healthcare services, but can also increase the costs of treatments.

\subsubsection{Long-term care costs}

29. Public expenditure on long-term care varies widely across G20 economies, ranging from around 2\% of GDP in Japan to around $0.5 \%$ of GDP in Italy and in the United States and even less in Australia (Figure 13). The variation reflects large differences in the balance between formal care provision and informal care (usually provided by families) and the share of costs that people are expected to pay out of pocket for LTC. In most economies, LTC is still largely provided informally by family caregivers. While public spending on LTC is generally low compared to pension and health expenditure, it has been increasing rapidly, by $4.6 \%$ annually on average across OECD countries between 2005 and 2015 (OECD, 2017 [27]).

30. Ageing will continue to exert pressure on LTC expenditure, especially due to the rapid increase in the share of people over 80 years old in the population. This may be partially offset by better health for longer in retirement (and excluding the death year). However, increased dependency due to chronic diseases such as dementia could exert additional cost pressure (OECD, $2017_{[27]}$ ). Rising trends in formal labour force participation, and geographic mobility whereby young people move to cities while ageing parents stay in rural areas, are also likely to reduce the 
provision of informal care and raise demand for formal LTC. Lower productivity gains in the care sector than in the rest of the economy can also push up LTC costs, but new technologies could in the future help improve the quality of LTC services and increase productivity. Advances in the areas of information processing and gathering, assistive technology, remote care, monitoring and self-management are particularly promising (ILO/OECD, $2019_{[28]}$ ).

Figure 13. Long-term care expenditures

Long-term care expenditure (health and social components) by government and compulsory insurance schemes, as a share of GDP, 2017 or latest available

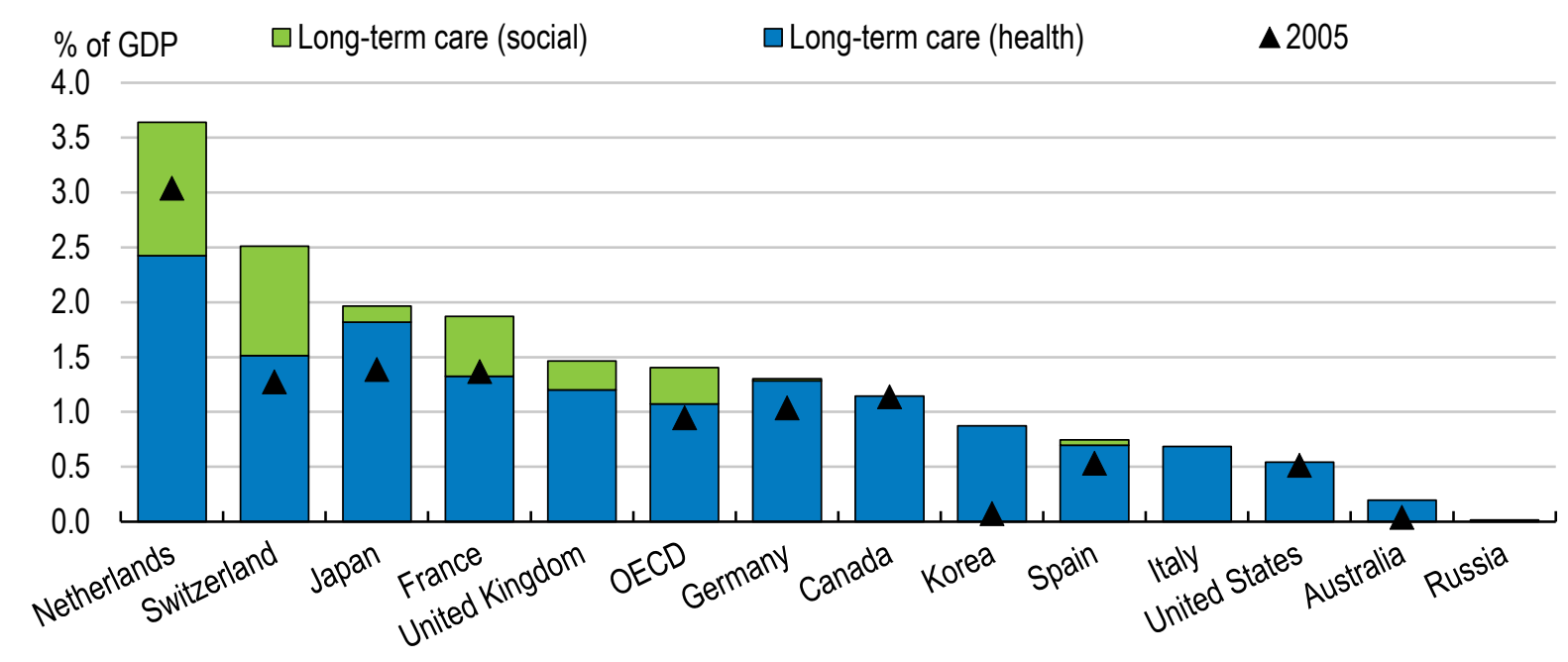

Note: The OECD aggregate is a simple average of OECD countries for which data are available. Data on longterm care expenditures are not available in 2005 for Italy, Russia and the United Kingdom. Source: OECD Health Statistics 2018.

StatLink 제프 http://dx.doi.org/10.1787/888933973629

31. On average across the OECD, projections indicate that public health and LTC spending could increase by up to, respectively, 6.3 and 1.3 percentage points of GDP by 2060 (De La Maisonneuve and Oliveira Martins, 2015 [24]). In major emerging economies, spending could increase much more rapidly but from a lower level.

\subsubsection{Combined fiscal stress from ageing-related spending}

32. Ageing will therefore create direct pressure on public finances through additional pension, health and long-term care expenditure. Moreover, tax revenue is more closely linked to employment whereas other primary expenditure is more closely linked to the total population. Declining employment rates can hence put further pressure on public finance from the revenue side. An indication of the overall stress on fiscal sustainability is given by estimating how much the tax burden would have to rise to keep debt-to-GDP ratios constant, assuming no further policy changes than those already legislated (Guillemette and Turner, 2018[2]). Taking into account the increase in pension, health care costs and other primary expenditure together with the downward pressure on revenues, tax revenue would have to increase between $4 \frac{1}{2}$ and $11 \frac{1}{2}$ percentage points of GDP by 2060 to keep debt at current levels in G20 countries (Figure 14).

33. Alternatively, assuming hypothetically that governments would not offset the ageing-related expenditure pressures through increases in tax revenues, cuts in other spending or 
reforms to improve the efficiency of spending, public debt levels would increase rapidly in both G20 advanced and emerging economies (Figure 15). This would be a particular challenge for the advanced economies where debt levels are already high.

34. These projections are not meant to represent the future, given that policies can be expected to evolve. However, they illustrate the risks that if reforms are too slow, pension, health and long-term care expenditures would either require substantial tax increases or crowd out possibly productive public spending to ensure fiscal sustainability.

Figure 14. Change in tax revenue necessary by 2060 to stabilise debt ratios at current levels

15

10
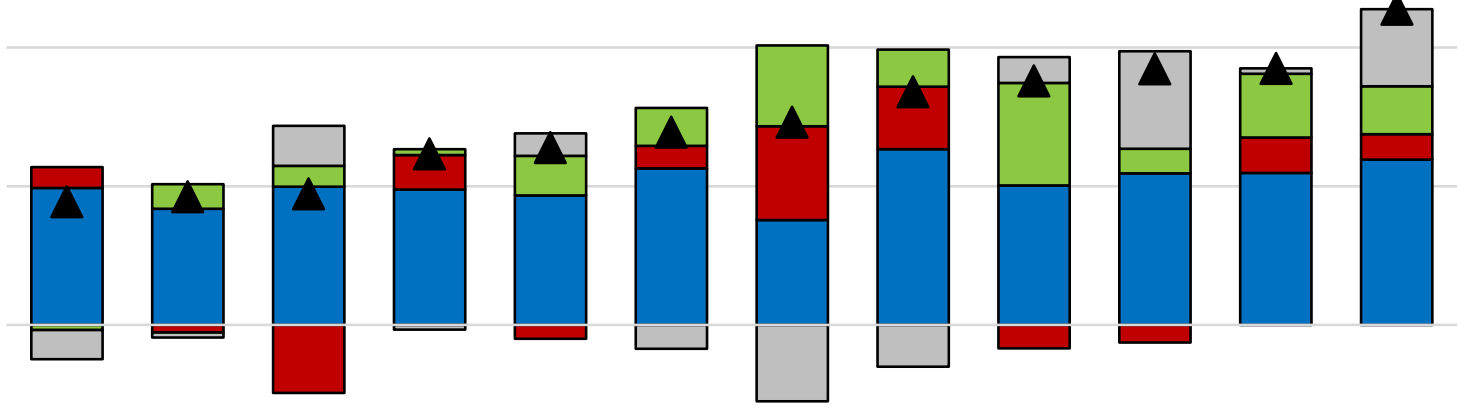

$-5$
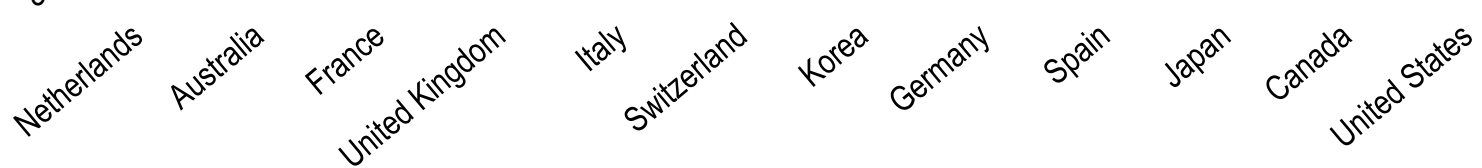

Note: Based on projected government pension expenditures from European Commission (2018[20]) and Standard and Poor's (2016[22]), and projected growth in public health care expenditure per capita with the methodology of Marino et al. (2017[23]). Other primary expenditure is assumed to remain constant in real terms on a per capita basis. "Other factors" mostly capture the initial gap between primary revenue and the level that would stabilise the debt to GDP ratio, but also changes in GDP growth rates over the projection period.

Source: Guillemette and Turner (2018[2]). 
Figure 15. Stylised debt scenarios

Gross public debt in \% of GDP
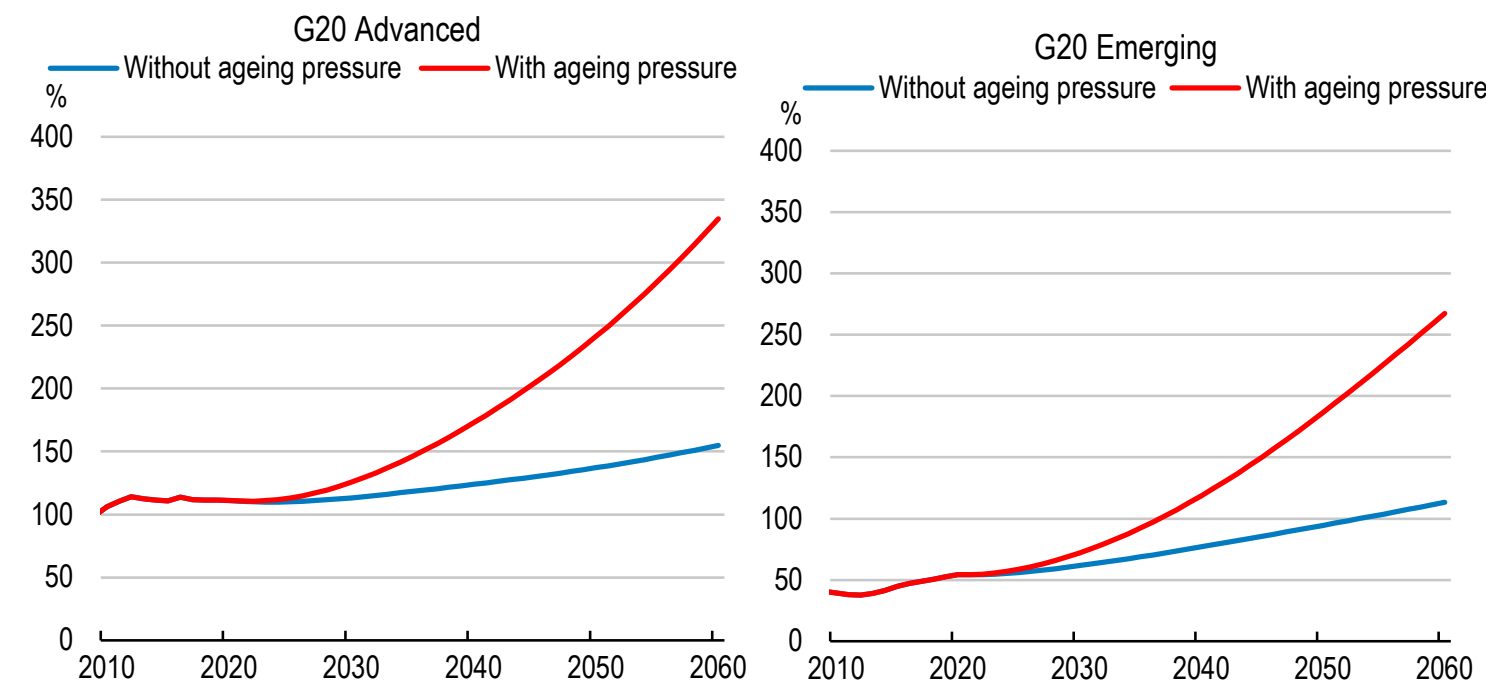

Note: Calculations based on a simple debt dynamics equation: $\Delta d_{t}=\frac{r-g}{1+g} * d_{t-1}-p b_{t}$, where $d$ is gross debt in percent of GDP, $r$ the real interest rate, $g$ the real growth rate and $p b$ the primary balance. In the scenario without ageing pressures, the cyclically adjusted primary balance as percent of GDP is held constant at the (projected) 2020 level. The ageing pressure scenario includes health and pension expenditures projections; other primary expenditures are assumed constant in real per capita terms. Primary revenues are held constant in percent of GDP. Growth and interest rate projections are based on the OECD Long-Term Model. Aggregates are weighted averages using GDP at market prices. The G20 Advanced aggregate includes Australia, Canada, France, Germany, Italy, Japan, Korea, the United Kingdom and the United States. The G20 Emerging aggregate includes Argentina, Brazil, China, Indonesia, India, Mexico, Russia, Saudi Arabia, South Africa and Turkey. Source: OECD calculations.

StatLink त्ञाज् http://dx.doi.org/10.1787/888933973667

\subsubsection{Challenges of insufficient coverage}

35. In most advanced economies, employees are well-covered by mandatory earningsrelated pension systems, but the coverage of the self-employed and of workers on non-standard contracts may be inadequate. In emerging-market economies, an additional challenge is that rapid ageing may occur before pension systems reach comprehensive coverage, especially where informality is high, exacerbating risks of old-age poverty. Low coverage may put a strain on public finances where safety net pensions take over. It also increases the burden on families and informal care to support the elderly. In EMEs, a range of reforms to expand mandatory pensions and promote formal work should be part of the policy responses to alleviate long-term fiscal and poverty concerns. For example, in 2015, Indonesia introduced a mandatory defined benefit scheme, which helped expand coverage.

36. In some countries, coverage challenges are compounded by structural changes in the labour market towards more non-standard work (part-time, temporary work, and selfemployment). Job stability - as measured by how long workers stay in a given job - has declined recently on average across OECD countries, and particularly for low-educated workers (OECD, $2019_{[29]}$ ) Even when tenure is declining because people have better opportunities to move between jobs, policies need to ensure that the fragmentation of careers does not penalise workers in terms of pension savings. Some countries are already taking steps to ensure that 
workers in new forms of work (including, for example, own-account workers ${ }^{4}$ ) are better covered by social protection systems, such as extending statutory access to existing schemes for the selfemployed and contract workers. For instance, in Germany and Australia, the self-employed can voluntarily join earnings-related schemes that are mandatory for employees; in Spain, the economically dependent self-employed (relying on a single client for at least $75 \%$ of their income) have access to health and accident insurance, pensions and unemployment benefits; and Chile is considering providing mandatory health and pension coverage for contract workers and the self-employed earning more than about twice the average national wage (OECD, 2019 $\left.{ }_{[30]}\right)$.

\subsection{Solvency and adequacy of funded pension schemes}

37. Demographic change will affect the financial position of private pension schemes and the adequacy of the income they provide in retirement. ${ }^{5}$ Private pension assets have grown steadily since the financial crisis and reached new heights in 2017. This sharp increase can be notably explained by the positive real returns that private pension funds experienced over the last decade $\left(\mathrm{OECD}, 2018_{[31]}\right)$ and by growing amounts of contributions $\left(\mathrm{OECD}, 2017_{[32]}\right)$. However, the coverage of the working-age population by private pension funds and their size vary widely across countries (Figure 16). Assets are particularly high in some advanced economies, such as the United States (145\% of GDP) or Australia (130\% of GDP) where private pensions are the main source of coverage, but remain relatively low in some fastgrowing emerging markets like China or India, at $1.6 \%$ and $1 \%$ of GDP respectively, where public schemes dominate and overall pension coverage is lower (OECD, 2018 [31] ). Private pension schemes tends to be more developed in countries where the coverage of public pension systems is low, where participation is mandatory rather than voluntary, and where tax incentives for retirement savings are strong. Even where coverage is high, workers tend to under-save and under-plan for retirement, particularly when they have low levels of financial literacy, which endangers their financial security at old age (Aegon, 2018[33]).

38. Occupational and personal plans coexist in most OECD countries, although at different degrees (Figure 17; Table 3). Occupational pension plans can be either classified as defined contribution (DC) or defined benefit (DB), depending on how pension benefits are calculated and who bears the risk (OECD, 2005 $\left.5_{[34]}\right)$. In DC plans, employees pay fixed contributions and accumulate assets over time, which will be eventually used to finance their retirement. Therefore, employees bear the brunt of risk as employers are not responsible for financing any funding shortfall. In DB plans, benefits are linked to members' salaries, length of employment or other factors; the sponsoring employers are responsible for guaranteeing promises and assume the risks. Hybrid DB plans involving some risk-sharing between employers and employees are under discussion in the Netherlands. Overall, personal plans and occupational DC plans have been gaining importance at the expense of occupational DB pension plans (OECD, $\left.2017_{[17]}\right)$. As a result, individuals will increasingly carry the financial and longevity risk in the future, which raises the importance of building financial skills and providing the tools for employees to plan for retirement. Furthermore, the most economically vulnerable often have less access to employer-sponsored plans. For instance in the United States, only $30 \%$ of workers with a high school degree were covered by a workplace retirement plan in 2017, as opposed to $52 \%$ of workers with a graduate degree (Ghilarducci, 2018 $8_{[35]}$ ).

\footnotetext{
${ }^{4}$ Own-account workers are those workers who, working on their own account or with one or more partners, hold the type of job defined as a self- employed job, and have not engaged on a continuous basis any employees to work for them during the reference period.

5 This section focuses on private pensions, but similar issues apply to funded public pension plans.
} 
Figure 16. Private pensions in OECD countries

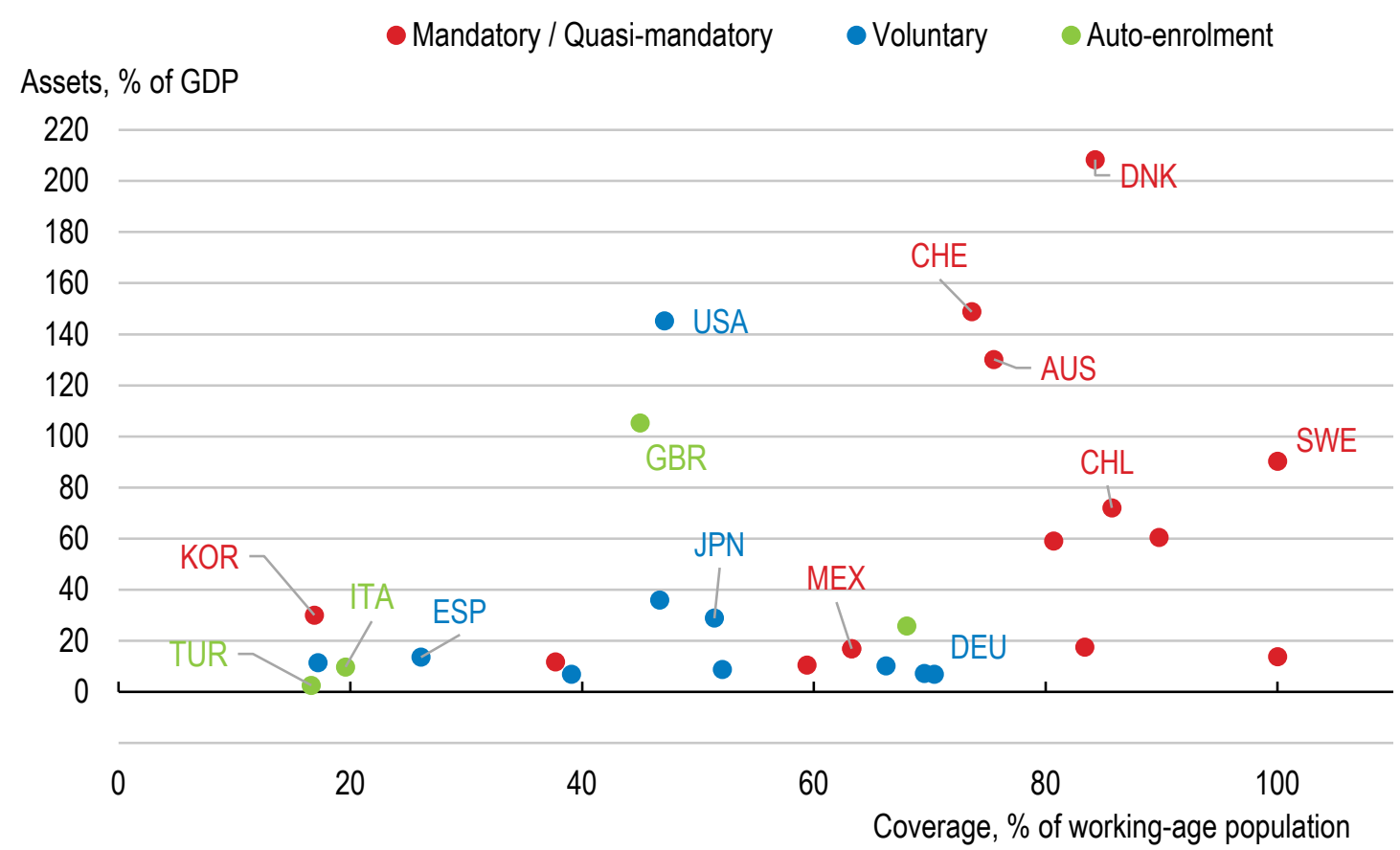

Source: Global Pension Statistics, OECD Economic Outlook database; and OECD calculations.

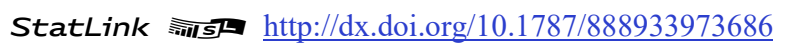

Figure 17. Structure of private pension systems

2016, as a percentage of total assets held in private pensions

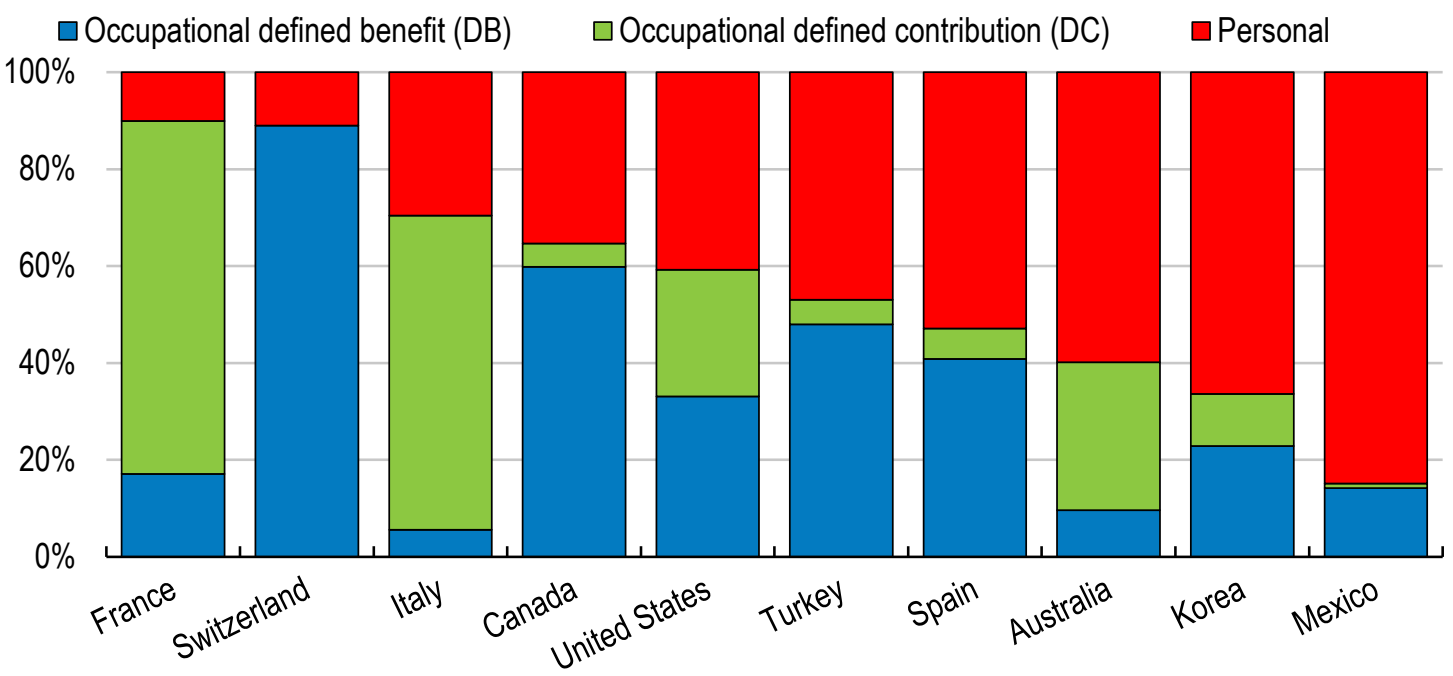

Source: OECD Global Pension Statistics.

StatLink ज्ञात http://dx.doi.org/10.1787/888933973705 
39. A key driver of sustainability for private pension systems is the evolution of interest rates and financial returns, which in turn will depend, in part, on the dynamics of savings and investment induced by ageing (see Box 1). Interest rates remaining at low levels for long would create pressure on the ability of DC plans to deliver sufficient income in retirement, as well as on the sustainability of DB pension arrangements. Assets may not grow as much as needed to back fixed promises to beneficiaries, thereby undermining the solvency position of DB pension funds (OECD, 2015 $[36])$. Furthermore, low interest rates increase the present value of private pension liabilities, which may further deteriorate the solvency position of pension funds. These could in consequence spur pension funds to engage in riskier investments in search for higher returns, or conversely to invest more in safer assets to meet regulatory requirements with the effect of further reducing their yields. At the same time, incentives for young households to save may be reduced in an environment of low interest rates, which may lead to lower contributions and eventually lower retirement income. Alternatively, low interest rates may force individuals enrolled in DC schemes to contribute more to obtain adequate retirement income, with negative effects on current consumption of younger generations.

40. Improved longevity is also likely to pose a challenge to private pension funds. Private pension funds' liabilities tend to have a longer duration due to the time horizon of their promises. If the amount of contributions does not increase over time, the assets of DB pension funds will have to finance promises over a longer period which exposes them to a reinvestment risk. In addition, the present value of future liabilities of pension funds depends on mortality assumptions. Therefore, future deviations in mortality improvements from those assumed will stress private pension funds' funding ratios $\left(\mathrm{OECD}, 2014_{[37]}\right)$. Risks to private pension funds' financial positions may also be amplified by socio-economic factors. Pension funds mostly cover people in the top income distribution. Mitigating the longevity risk will thus be more expensive if the divergence of life expectancies continues between these groups and lower socioeconomic groups (OECD, 2016[38]).

\section{Policy actions to help ageing societies thrive}

41.

The fiscal, productivity and inclusiveness challenges of demographic change call for a comprehensive approach across policy areas. The appropriate policy response will depend on each country's situation with respect to ageing, macroeconomic developments and social preferences. To deal with multifaceted challenges, ambitious policy packages are likely to be required, comprising a combination of reforming public and private pension systems, health and LTC to ensure their sustainability, addressing old-age poverty, promoting labour force participation and seizing opportunities of the "silver economy" for innovation.

\subsection{Promoting financially sustainable pension, health and long-term care systems}

\subsubsection{Improving the design of mandatory pension systems}

42. In most advanced countries, public pension systems, often financed on a PAYG basis and structured as a defined benefit system, are the main source of coverage. The design of pension schemes needs to address the triple challenge of ensuring fiscal sustainability, providing adequate incomes in retirement and ensuring intergenerational fairness. Direct responses will need to be adapted to each country's policy priorities, fiscal and demographic situation, risk tolerance and existing policy and institutional settings. They can include action on various parameters of public pension design - contribution periods and rates, replacement rates, 
flexibility to combine work and pensions, diversity of pension schemes, coverage, etc. - bearing in mind the impact of such reforms on public finances, growth and inequalities (see Annex Table 4). Ensuring sustainable public finances in light of ageing populations, and making sure that people have adequate retirement income, also requires to promote complementary welldesigned funded pension arrangements. The OECD has always stressed the need to diversify the sources to finance retirement, and that funded and PAYG-financed pension arrangements need to co-exist complementing each other (OECD, 2016 $[39])$. Moreover, complementary action to ensure sustainable public finances, addressed below, should focus on mitigating the impact of ageing on labour supply and making use of technology and innovation to contain increases in health and long-term care costs.

43. In response to rising pressures on public finances from ageing populations, many countries have reformed their pension systems in recent years (see Annex Table 5 for an overview of recent reforms). Reforms have included raising contribution rates (e.g. Canada, United Kingdom), cutting initial benefits or limiting the indexation of pensions to inflation and wages (e.g. Argentina), indexation to life expectancy (e.g. Japan), raising retirement ages (e.g. Indonesia, Russia, United Kingdom), and closing early pathways into retirement via reforms of the unemployment insurance or disability pension schemes. An important challenge for many countries is to fully implement legislated reforms to improve sustainability, and to withstand pressures to backtrack on reforms given that pension reforms are typically not popular (Box 2).

\section{Box 2. Political economy of pension reforms}

The pace of reforms needed to address ageing-related challenges differs across countries, depending on their demographic or macroeconomic situation. In countries already facing the pressure of ageing, governments must take action to ensure fiscal sustainability and provide adequate incomes in retirement. It is also important to discuss and plan reforms to anticipate future pressures in countries where population is still younger but ageing rapidly.

Structural reforms, especially on pensions, can be politically costly as they typically imply increasing contributions, reducing or limiting benefits, or working longer. As a result, governments may face pressure, particularly from those most affected, not to move forward with reforms or to backtrack already legislated measures.

This might become even more challenging in ageing societies, as older people, who tend to vote more, are likely to be less supportive of reforms that involve lowering benefits or increasing the retirement age (Casamatta and Batté, 2016 [40] $)$. At the same time, young people are increasingly losing interest in politics (OECD, 2019 [41]). In 2012-2013 for instance, voter turnout averaged $86 \%$ among voters aged 55 or more in OECD countries (Figure 18), 16 percentage points more than for young adults.

It is therefore essential for governments to announce and pass reforms at the right time, with effective communication and consultation beforehand to secure wide buy-in from stakeholders. 


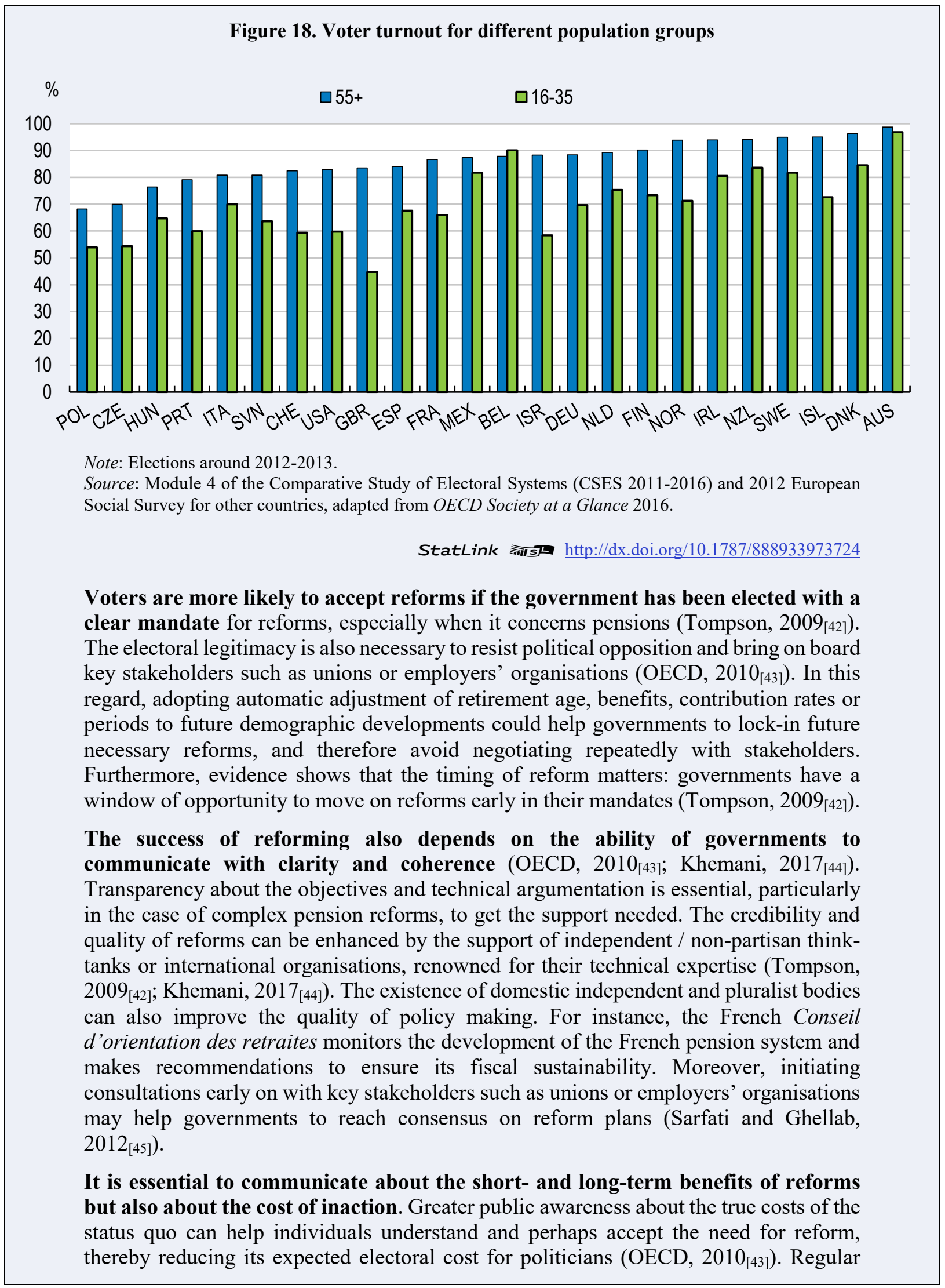


updates on demographic change and its long-term impact on growth and public finances, such as in the Australian Intergenerational Reports, can ensure that the public conversation remains active and the public opinion is aware of the urgency and help convince about the need for reform.

Reforming pension systems is preferable when the economy is doing well and when macroeconomic policies have space to provide support. A strong macroeconomic position and sound public finances may indeed help governments to mitigate the shortterm costs of pension reforms, as more resources may be available to compensate the losers $\left(\right.$ OECD, 2010 $\left.0_{[43]}\right)$. The short-term impact of reforms may depend on their type. For instance, increases in the retirement age are likely to have positive effects on demand in the short-run while the effect is less clear in the cases of benefit reductions or increases in contribution rates (Caldera Sánchez, de Serres and Yashiro, 2016[46]).

Yet, evidence shows that pension reforms are more likely to be implemented during downturns (Beetsma, Romp and Van Maurik, 2017 $7_{[47]}$ ) and when public finances are under stress, creating a sense of inevitability of reforms. Pension reforms adopted during times of crisis are less likely to be successful in the long-run, especially when social dialogue is limited (Sarfati and Ghellab, 2012 ${ }_{[45]}$ ). However, reforming pension or health systems during stress times can increase the confidence in the sustainability and effectiveness of public finances, thereby creating some space for short-term stimulus measures which may mitigate the reforms' short-term costs (Caldera Sánchez, de Serres and Yashiro, 2016[46]).

The packaging and sequencing of reforms is an important element. It may be preferable to package pension reforms with reforms of skills policies, especially targeted at upgrading senior workers' skills, to help cushion the costs for vulnerable workers rather than with labour market reforms. Pursuing simultaneously pension and labour market reforms may be more difficult given the labour-market implications of many retirement reforms (Tompson, $2009_{[42]}$ ). Governments' political capital would risk being further undermined, which could make it difficult to pursue the combined reform.

Changes in pension policies may disproportionally affect older workers, who have already set their career and savings choices and might have not enough time to adapt their behaviour. Younger people, on the other hand, have a longer horizon to adjust their career plans and arrangements for financing retirement (OECD, 2010 [43] $)$. As a result, it might be more socially acceptable to put in place long transition periods and apply the new measures only to future cases in order to secure their adoption. To allow younger generations to adapt their labour supply and saving choices and plan for the long term, it is important to ensure that the policy settings determining future retirement incomes are as predictable as possible, for instance by introducing automatic adjustments rather than implementing frequent one-off reforms.

44.

Raising the retirement age can help both increase the labour force participation of older workers and maintain pension levels in the face of rising pressures. Normal retirement ages have increased over the last two decades in almost all OECD countries, and in G20 emerging economies (e.g. Indonesia, Russia). Based on legislated measures, the statutory retirement age will keep increasing, by 1.4 years for men and 1 year for women on average across G20 countries by 2060 (Figure 20). The increase will be larger in advanced G20 economies, by 1.9 years for men and 2.2 years for women, reaching just over 66 years. However, the increase in the statutory retirement age has so far not been high enough to keep pace with 
rising life expectancy in most countries (Figure 19) and the share of adult life spent in retirement has increased (OECD, 2019 $\left.9_{[48]}\right)$.

45. A few countries (e.g. Denmark, Finland, Italy, the Netherlands and Portugal) have established an automatic link through which a given share of future increases in life expectancy will be reflected in the normal retirement age $\left(\right.$ OECD, $\left.2017_{[17]}\right)$. The approach taken by Portugal, in particular, strikes a balance between the need to improve the sustainability of public pensions and broader welfare considerations: the statutory retirement age is set to increase automatically in the future by two-thirds of increases in life expectancy. Assuming all OECD countries adopted a similar approach by 2020 (except for countries where currently legislated increases are even larger) this would raise senior employment rates and GDP per capita in the long-term, alleviating the stress on public finances (Figure 21 and Geppert, Guillemette and Turner (2019[49])). However, such reforms are not easy to implement politically and require careful communication, as discussed in Box 2.

Figure 19. Change in normal retirement age relative to life expectancy at 65

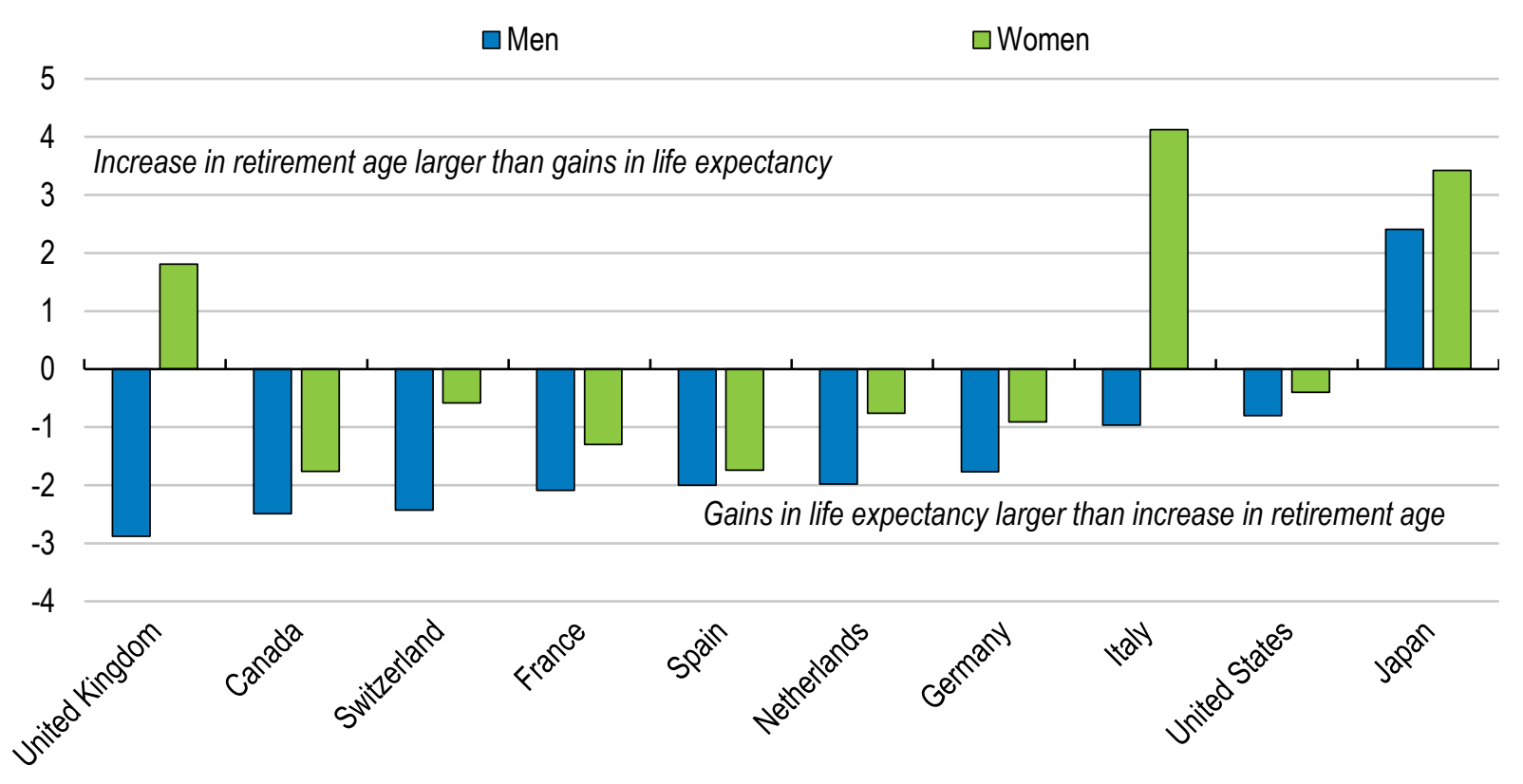

Note: The figure shows the differences between the increase in the normal retirement age and the increase in life expectancy at age 65 over the period 2002 to 2017 . A negative value implies that the normal retirement age has not kept pace with the increase in life expectancy. The normal retirement age is the age at which an individual who entered the labour market at age 25 and had a full career becomes eligible for full pensions from all mandatory pension schemes.

Source: Social Security Programs Throughout the World (2002-2018); MISSOC (2017); OECD Pensions at a Glance 2017; and UN World Population Prospects - The 2017 Revision. 
Figure 20. The retirement age will increase in about half of G20 economies

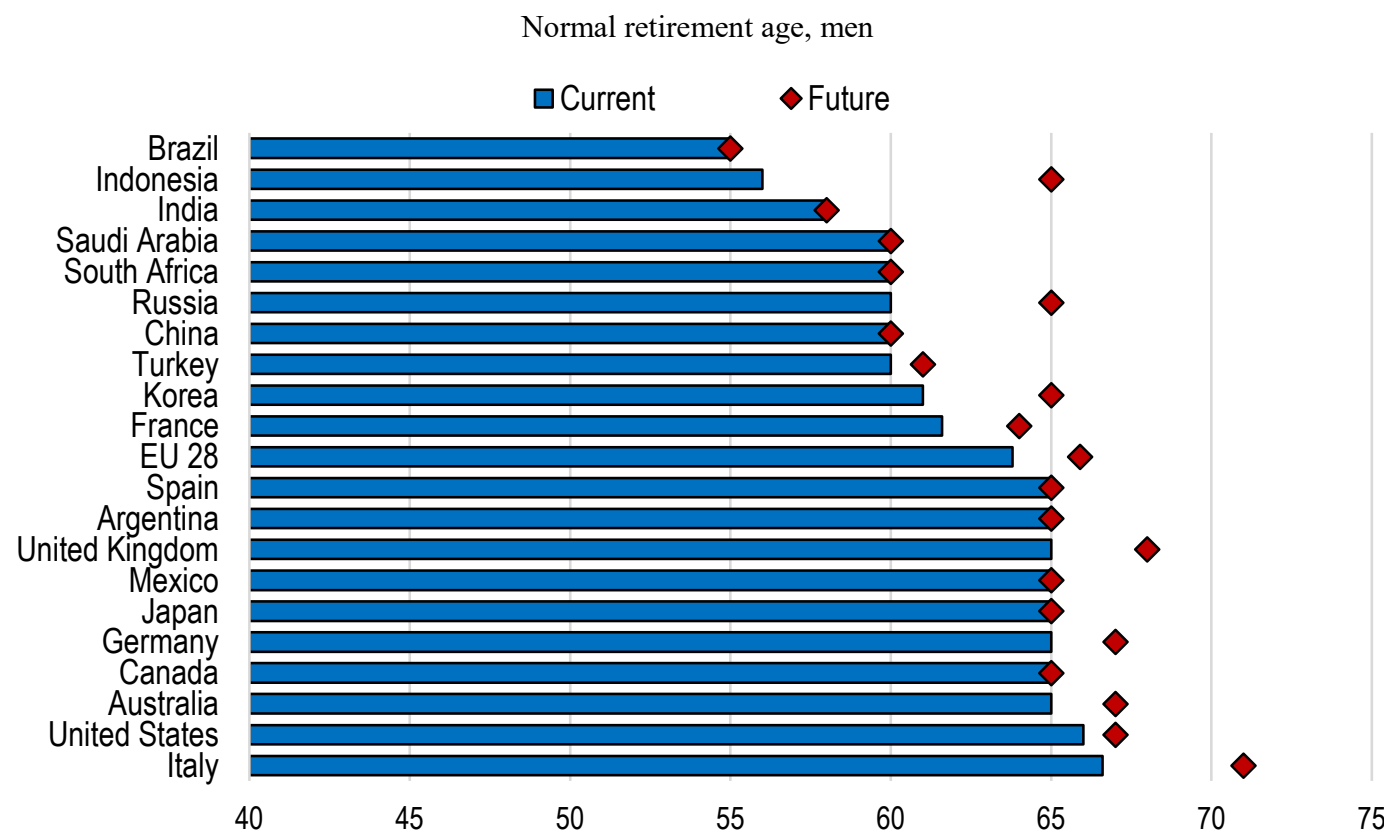

Note: Retirement age for men entering the labour at age 20. Future retirement age is for people who entered the labour force in 2016, based on currently legislated provisions. Announced but not yet legislated measures are not reflected. The normal retirement age is the age at which an individual who entered the labour market at age 25 and had a full career becomes eligible for full pensions from all mandatory pension schemes.

Source: OECD Pensions at a Glance dataset.

StatLink 세내 http://dx.doi.org/10.1787/888933973762

Figure 21. Increase in GDP per capita by 2030 if minimum and statutory retirement ages rise by at least two-thirds of gains in life expectancy at 65

Percentage difference relative to baseline

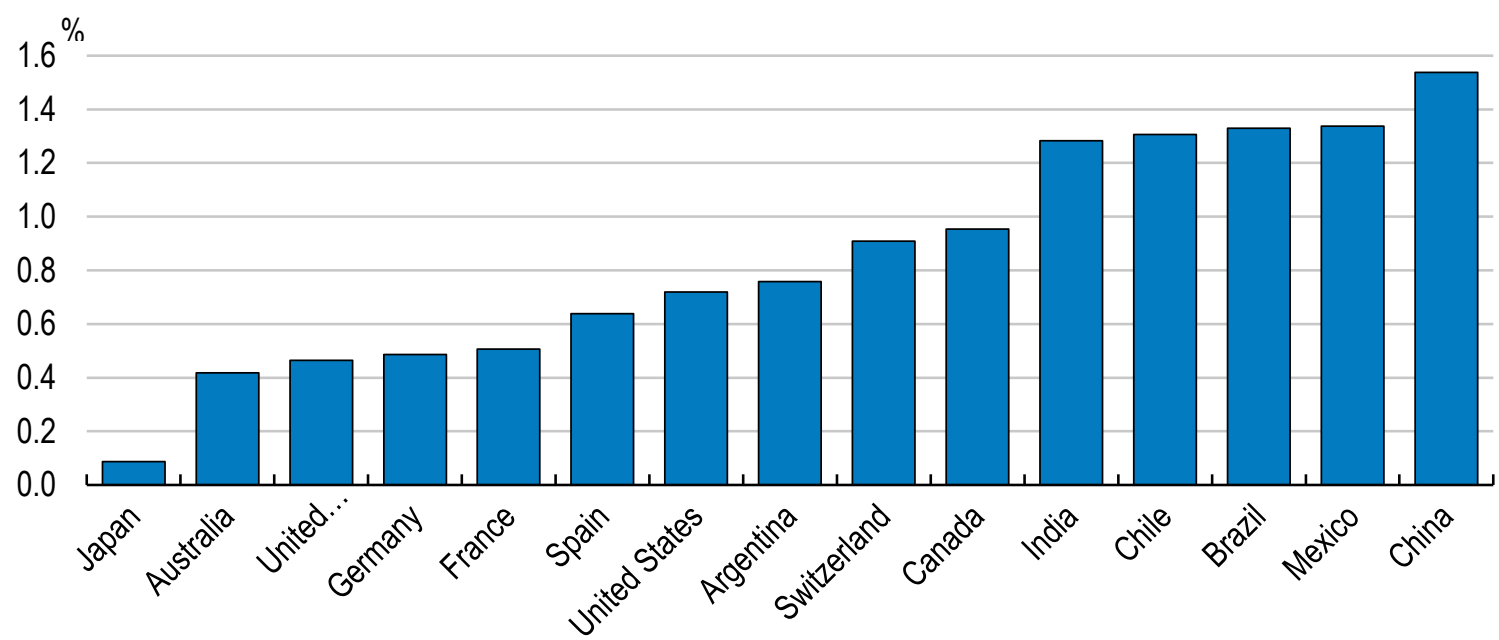

Note: Life expectancy at age 65 is set to increase by 2 years on average by 2030 across G20 countries. Source: OECD calculations. 
46. Unifying pension frameworks for all workers, phasing out special regimes, would help enhance both efficiency and equity in pension systems. Differences in contributions and pension rights among different categories of workers, in particular in separate pension schemes for civil servants, can be substantial and fuel dissatisfaction with public pension systems. A unified pension framework enhances transparency and fairness, facilitates mobility across professions and reduces costs. On the equity side, it is difficult to argue today that for instance civil servants and public sector workers require higher income replacement in retirement than their private sector counterparts. On the efficiency side, there are significant economies of scale in managing unified pension systems, for example in contribution collection, recordkeeping and benefit payment. Moreover, restraining labour mobility across sectors (e.g. with vested periods or limited portability) is inefficient, introducing rigidities in individual career management and restricting workers' capacity to adapt to sectorial shifts and seize new employment opportunities (OECD, 2016 $[39])$.

47. However, policymakers should take into account the potentially regressive effects of pension reforms when raising the statutory retirement age and phasing out special schemes. Lower socio-economic groups have shorter life expectancy and will see their pension wealth reduced relatively more if the retirement age increases without a corresponding gain in life expectancy, although the effect is relatively small ${ }^{6}$ (OECD, 2017 $\left.[1]\right)$. While working longer on average will be required as average life expectancy increases, people in manual jobs not only have less expected years in retirement but also may not be physically able to work longer. Some countries have explored compensating undesirable inequality outcomes by introducing more granularity in retirement eligibility based on people's skills and the physical requirements of their jobs. However, these schemes also tend to introduce administrative complexity for firms and workers and may create distorted incentives.

48. To respond to both financing challenges and diverse wishes among workers, pension design should allow for a phased approach to retirement. Flexible retirement consists in the option to continue to work, often part-time, while drawing at least a partial pension, or to choose when to retire with pension rights adjusted in an actuarially neutral way. Recent reforms in this direction were passed for instance in Germany, where the 2014 pension reform allowed employers and employees to easily extend an existing contract beyond the pensionable age, and pension and wage earnings can be combined in a more flexible way since 2017. Phased retirement can benefit people who want to work part-time at older age and smooth their income from work and pensions. It incentivises people to work longer and increase their pension entitlements, especially for people with incomplete or interrupted career paths. However, it may also have the effect of inducing people to retire too early if they underestimate their future financial needs. Options for flexible retirement must therefore come with renewed efforts to foster financial literacy, and be consistent with the financial balance of the pension system. Many countries have already tightened early retirement rules (e.g. Austria, Belgium, Germany, Finland). Since 2002, the early retirement age increased by an average of 14 months in OECD countries, against 8 months for the normal retirement age (OECD, $\left.2017_{[17]}\right)$.

49. Flexible retirement should come with neither financial disincentives for working past the normal retirement age, nor excessive penalties for retiring early. Most countries allow people who have fully retired to engage in paid work, but some apply earnings limits above which pension benefits are reduced. In other instances, financial disincentives come

\footnotetext{
${ }^{6}$ Holding everything else constant, if retirement ages were increased by three years between 2015 and 2060, the relative pension wealth of the low-income versus high-income groups would be reduced by $2.2 \%$ on average across countries, when only taking into account differences in life expectancy.
} 
from the fact that working retirees must continue to pay pension contributions without earning additional pension entitlements. The adjustment of entitlements for either postponing retirement or retiring early should be based on actuarial neutrality to avoid these distortive effects. This amounts to a bonus estimated at about $5.5 \%$ on past entitlements on average in OECD countries for each year of deferral (OECD, 2017 $[17])$. Conversely, the reward for continuing working past the pensionable age should not be larger than justified by the shorter retirement period, which would add to the pension provider's costs.

50. Net replacement rates vary considerably across G20 countries (Figure 22). Low replacement rates exacerbate the risk of relative poverty at old age. Cutting benefits and limiting the indexation of pensions (for instance fully indexing pensions to prices rather than to wages) can improve fiscal sustainability, but can jeopardise the adequacy of pension incomes and can make pensioners more vulnerable to old-age poverty. Considering these options should be mostly confined to cases where net replacement rates are high and the stress on public finances is acute. Furthermore, funded DC schemes and notional DC systems automatically adjust annuities to changes in longevity. Some countries (e.g. Japan, Germany) also include automatic adjustment of pension benefits in DB or point-based schemes based on changes in life expectancy, in the ratio of contributors to pensioners or in macroeconomic parameters. These automatic links help lower the financial pressure, but require efficient complementary measures to boost employment at older age so as not to result in consistently lower pension levels and heightened poverty risk among pensioners.

Figure 22. Projected future net replacement rates from mandatory pension schemes

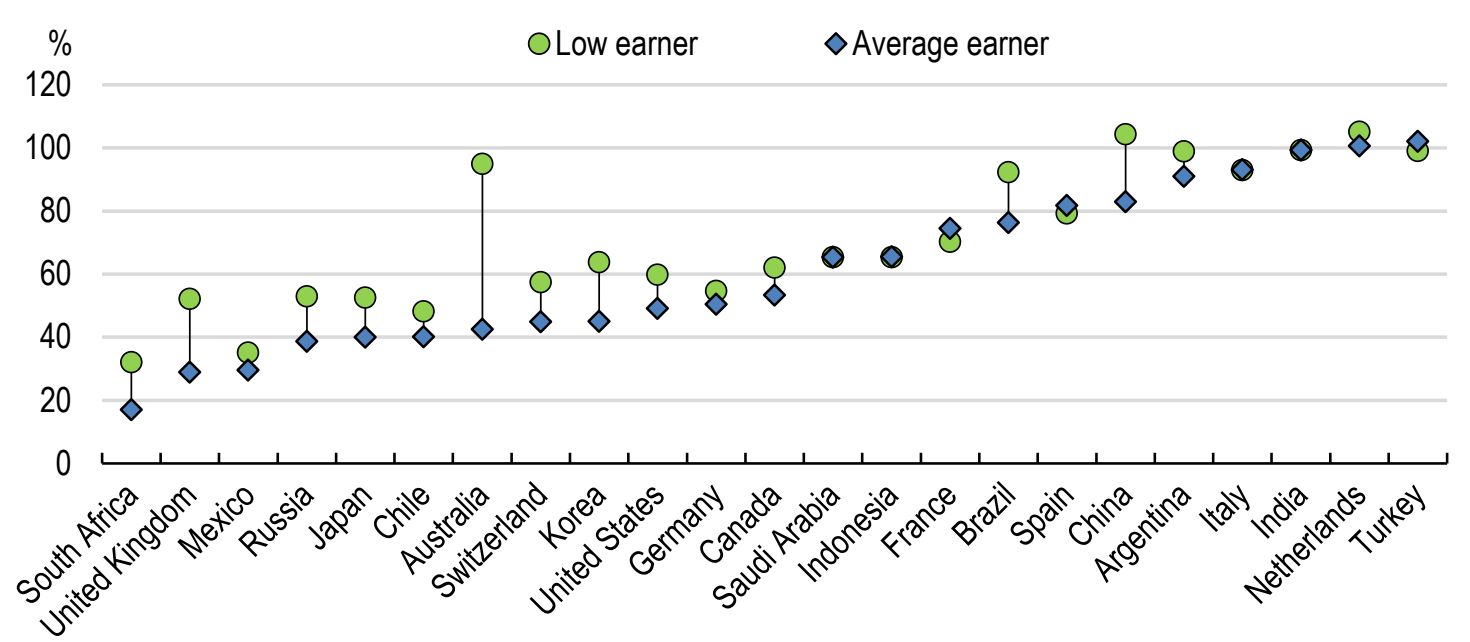

Note: The theoretical future net replacement rate is estimated assuming labour market entry at age 20 in 2016 and a working life equal to what is required to reach the normal pensionable age in each country. This normal pensionable age is defined as the age at which individuals can first withdraw their full pension benefits, without actuarial reductions or penalties. The net replacement rates shown are calculated for mandatory schemes for an individual with $100 \%$ and $50 \%$ of average worker earnings.

Source: OECD calculations based on the pension model, see OECD $\left(2017_{[17]}\right)$.

StatLink 세내 http://dx.doi.org/10.1787/888933973800

51. Finally, higher contributions may improve financial sustainability and/or pension adequacy but it raises non-wage costs for employers, which in turn may weigh on net wages and employment over time. Increasing contributions may also raise questions of intergenerational fairness by placing the burden on younger generations. In countries where pension contribution 
rates are relatively low (e.g. Australia, Canada, Korea and Mexico), lower net wages might be acceptable to workers if this preserves or raises retirement income levels in the future (Figure 23).

Figure 23. Mandatory pension contribution rates for an average worker in $\mathbf{2 0 1 6}$

$\%$ of the worker's gross earnings

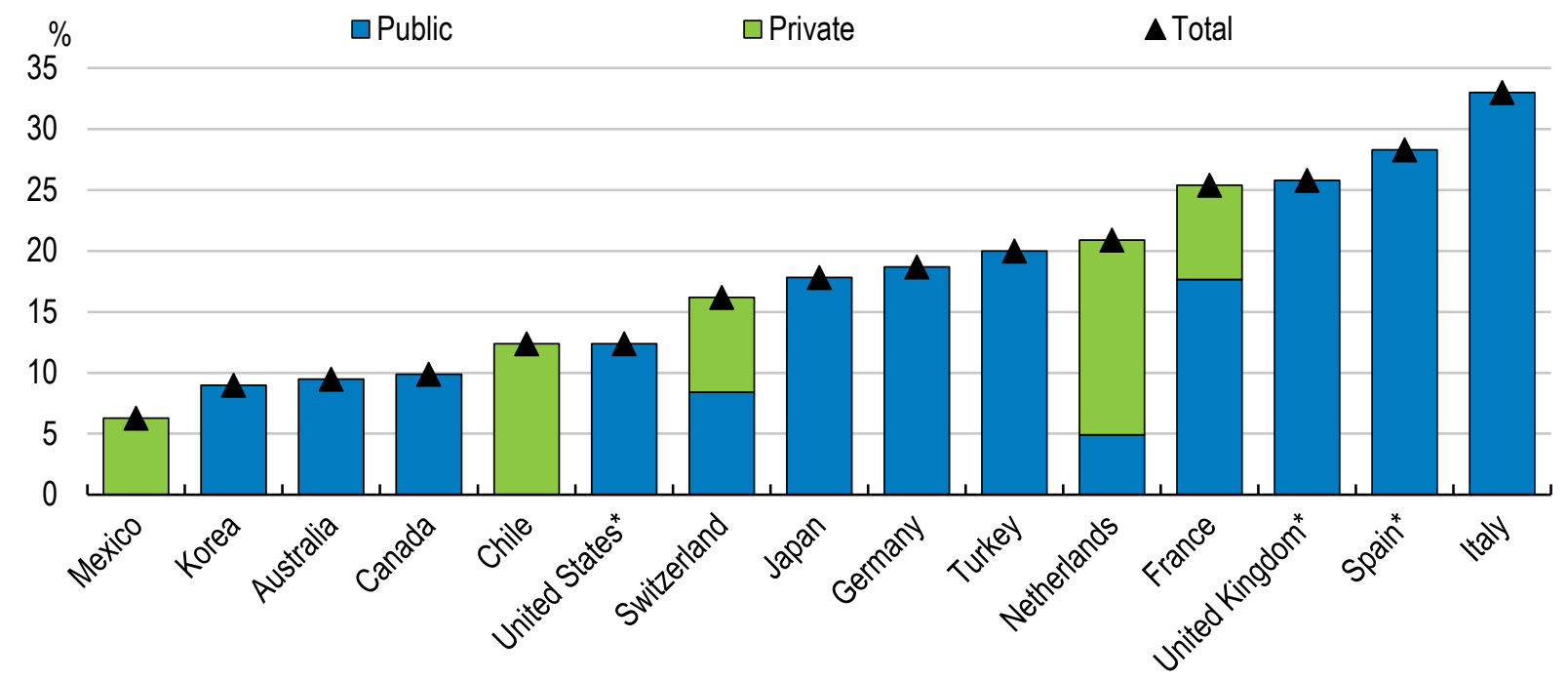

Note: Contribution rates include employee and employer contributions. The rates for both employee and employer are based on the worker's gross earnings. * indicates social insurance contributions, including for non-pension benefits.

Source: OECD Pensions at a Glance 2017.

StatLink त्राज http://dx.doi.org/10.1787/888933973819

52.

Public pension systems should access and use appropriate and timely information on mortality and life expectancy in order to manage longevity risks efficiently. Projections of public pension sustainability should use reliable and regularly updated mortality tables incorporating future improvements in longevity and attaching probabilities to different forecasts to highlight the degree of uncertainty. Furthermore, independent councils could be commissioned to provide comprehensive evaluations on demographic developments and on pensions, which could help governments manage public finances effectively. In the United States for example, the Government Accountability Office (GAO) is in charge of assessing the US retirement system and proposing recommendations to improve the efficiency of public expenditures on pensions. Similar missions have also been assigned to independent authorities in Canada (Canadian Pension and Benefits Institute), France (Conseil d'orientation des retraites) or the Netherlands (CPB Bureau for Economic Policy Analysis). In the same vein, regularly updated reports looking at long-term demographics developments such as the Australian Intergenerational Report are useful to policymakers when taking action on pensions.

53. Safety net pensions - means-tested, non-contributory basic pensions - as well as minimum pensions in contributory schemes, play a key role in preventing poverty at old age, especially for low earners, people with non-standard or incomplete careers and women who interrupted their careers to care for children. About three in ten older people receive support from such first-tier pensions on average in the OECD. They are typically funded from general government revenue. Countries combining low safety-net benefits and high rates of old-age poverty may need to make space for higher spending on basic and minimum pensions, offsetting 
it by either cutting other categories of public expenditure or, where government revenue is a low share of GDP, by raising more revenue. For instance in Japan, part of the revenue from the consumption tax hike planned in 2019 is set to cover rising costs of social security and elderly care.

54. In countries with a large informal economy, promoting formalisation would help expand the scope of contributory schemes and reduce the reliance on safety net pensions. Tackling informality requires a comprehensive strategy that simultaneously addresses all the main factors that drive it. Past experience suggests that narrow reforms that focus on only one specific element affecting formality tend to have only modest effects. Policy action to reduce informality should rest on three pillars: increasing the perceived benefits of formal employment, reducing the costs of formalisation, and strengthening enforcement methods $\left(\mathrm{OECD}, 2015_{[50]}\right)$. First, firms and workers need to clearly recognise the benefits of formalisation. Governments should improve the quality of the public services they deliver and strengthen the link between contributions and benefits in social protection schemes. Better public services will increase people's trust in their governments and strengthen their motivation to join the formal sector. The introduction of individual unemployment saving accounts (as in Chile since 2002) is a good example of how the costs of formalisation can be linked to its benefits, providing incentives to workers to join the formal sector. Another example is South Africa, where domestic workers were included in the Unemployment Insurance Fund in 2003 and increasingly brought into the formal sector. Second, the costs of formality should be lowered for employers and the self-employed. Simplified tax and administrative systems, streamlined registration processes and a reduction in red tape are crucial steps in the right direction. Brazil provides a good example of the benefits of this approach. Over the past two decades, Brazil adopted a number of policy measures to reduce the costs of formality, such as the "Simples Law" that introduced a more progressive tax structure and simplified the collection of taxes and social security contributions. It is estimated that these measures contributed to the formalisation of 500000 microenterprises accounting for 2 million jobs from 2000 to 2005 (Delgado et al., 2007 [51]). Third, compliance with regulations should be enhanced through better enforcement methods. Enforcement agencies, such as labour inspectorates, should be given sufficient resources and well-trained personnel to carry out their work effectively. Compliance can also be enhanced through the establishment of social norms that promote a responsible business conduct.

\subsubsection{Incentivising savings and managing risks in private pension schemes}

55. The existing mix of public and private pension schemes reflects policy and social choices in each country. With increased stress on public pensions, the reliance on private pensions is likely to rise in many countries. Within private systems, pensions are shifting away from employer-sponsored schemes towards personal retirement saving plans, raising the risk of insufficient contributions. Policies will need to adjust as risks are increasingly transferred from states and employers to individuals.

56. A first priority is to ensure that the accumulation phase is internally coherent with the pay-out phase, especially at a time where longevity is increasing. Individuals will be more and more responsible for building assets to finance their retirement, but tend to underestimate how long they will stay in retirement and their financial needs at old age (Aegon, $2018_{[33]}$ ). Policies should therefore encourage people to contribute more and for longer periods. A number of countries have already achieved high coverage rates through compulsory participation in private pension schemes (Figure 16). Introducing automatic enrolment systems tends to be an efficient alternative to increase participation. In such systems, people are automatically signed up to a pension plan but are free to opt out at some point. A number of G20 countries such as the United Kingdom, Turkey and Germany have recently implemented those 
systems. The evidence shows that enrolees usually continue to participate, in part for behavioural reasons. However, the success of automatic enrolment is not granted and depends on several factors. It is important to make automatic enrolment mandatory for employers in parallel, to lower entry barriers to make it more accessible and to introduce financial incentives to minimise optout rates. Schemes that allow workers to opt for regular increases in contribution rates or to automatically allocate a portion of future salary increases towards their retirement savings are also effective to raise contributions gradually over time (Thaler and Benartzi, 2004 [52]).

57. Simplifying the contribution process may increase voluntary savings, in particular in personal pension systems as individuals may find it difficult to save for retirement without the involvement of employers. Mexico introduced a new strategy to promote voluntary savings in the pension system to encourage all types of workers, formal and informal, to save for retirement. The strategy includes more and better information for people through communication campaigns and websites, a network of more than 7000 convenience stores where people can deposit voluntary savings, the use of debit cards to save a proportion of spending through an application, and the launch of an application where people can have access to many services, including opening a pension account and saving online. The results are promising so far, with the balance of voluntary savings growing on average by 33\% annually since 2014 (OECD, 2018 [53]).

58. Improving the structure of incentives can help expand coverage and increase contributions. A number of countries have tax incentives in place. However, their effectiveness must be assessed against the substantial fiscal cost and potential regressive effect, as high earners de facto receive larger subsidies compared to tax-exempt low-income workers (OECD, 2017 [54]; 2017 $[55]$; OECD, 2018 $8_{[56]}$ ). Policymakers could consider reviewing and harmonising tax treatments and simplifying them, especially in countries where financial literacy is low (see Figure 26). There can be a case to pare back excessively generous tax concessions which are mainly benefiting the top of the income distribution, as Australia did in the Superannuation Taxation Reform of 2016 (OECD, 2017 [57]).

59. Better-targeted options to encourage participation would use government subsidies such as matching contributions, capped to limit regressivity, or fixed nominal subsidies (OECD, 2018[53]). Matching contributions correspond to a subsidy, the match rate, based on the individual's own contribution. By contrast, all eligible individuals receive the same amount in the case of fixed nominal subsidies. Both are more effective than tax incentives at increasing participation in retirement savings plans by low-income earners, who may have insufficient tax liability to benefit from the tax relief. These types of incentives are increasingly used in OECD countries (Table 2), often with success. In Turkey for instance, the number of new participants in private pensions increased by $65 \%$ between 2012 and 2013 after the introduction of government matching contributions.

Table 2. Government non-tax financial incentives in OECD countries

\begin{tabular}{cc}
\hline Matching contribution (match rate) & Fixed nominal subsidies \\
\hline Australia $(50 \%)$, Austria $(4.25 \%)$, Chile $(50 \% \text { or } 15 \%)^{1}$, Hungary $(20 \%)$, & Chile, Germany, \\
Mexico $(325 \%)^{2}$, New Zealand $(50 \%)$, Turkey $(25 \%)$, United States $(50 \%$ to & Lithuania, Mexico, \\
$100 \%)^{3}$ & Turkey \\
\hline
\end{tabular}

Note: 1 . Chile has two different matching programmes, one for young low earners $(50 \%$ match rate) and one for voluntary contributors (15\%) matching rate. 2 . The matching programme for Mexico only applies to public sector workers. 3. The matching programme for the United States refers to the Thrift Savings Plan for federal employees. The first 3\% of employee contributions are matched dollar-for-dollar, while the next $2 \%$ are matched at 50 cents on the dollar.

Source: OECD (2018[53]). 
60

It is important to protect individuals as they will be increasingly responsible for financing their retirement and will therefore have to assume more risks. Annuitisation of accumulated assets should be promoted for the pay-out phase in order to limit longevity risks, particularly if people rely exclusively on those assets to finance their retirement, and incentives to take lump-sum payments could be reduced. The take-up of annuities could be promoted by establishing it as default or through financial incentives. For instance in Turkey, the government promotes annuities by paying a subsidy equal to $5 \%$ of the account balance at retirement to participants in the automatic enrolment scheme purchasing an annuity paid over at least 10 years $\left(\mathrm{OECD}, 2018_{[53]}\right)$. However, annuitisation rates based on average mortality rates may be unfavourable to low earners.

61. Furthermore, policymakers should promote competition among private pension providers in order to reduce fees and improve efficiency. This needs to be complemented by more transparent and accessible information so that people are able to easily switch providers. Investments should also be adapted to different individual risk profiles. Introducing minimum return guarantees is an efficient way to mitigate market risks on retirement income, and can also potentially improve public perception and confidence in private pension plans. In addition, offering guarantees on the nominal value of contributions would attract the most risk-averse individuals.

62. Private pension funds should be able to access appropriate and timely information on mortality and life expectancy in order to manage longevity risks efficiently (OECD, 2014 $\left.{ }_{[58]}\right)$. Reliable mortality tables based on stochastic forecasts should be made publicly available by statistical agencies and be updated regularly. Regulators should ensure that providers use these tables. Some aspects of the financial supervision of pension funds could also be strengthened, notably on monitoring "search for yield" behaviour and the use of derivatives for speculative purposes.

\subsubsection{Promoting healthy ageing and containing costs in the health sectors}

63. Health spending in most G20 economies has grown rapidly over the past decades. Higher health spending has contributed to important progress in health outcomes, including increasing life expectancy. Sustaining and improving health outcomes without endangering fiscal sustainability will require ambitious policy action and effective co-operation between Health and Finance Ministries.

64. Health generally deteriorates with age. There are also marked socio-economic differences - the share of low-educated people aged 65 reporting bad health is almost twice that of high-educated people (Figure 24). The effect of ageing on future health care expenditures will crucially depend on whether gains in longevity will translate into further improvements in years in good health. Projections for OECD economies indicate that effective health promotion policies could dampen the increase in total (private and public) health care costs by around 0.3 percentage points of GDP by 2030 - from $8.8 \%$ in 2015 to $9.7 \%$ of GDP in 2030, instead of $10 \%$ of GDP in 2030 in the baseline (Lorenzoni et al., 2019 [26]) . 
Figure 24. Health worsens with age, especially for lower educated people

Share of people reporting bad health by age, gender, and education

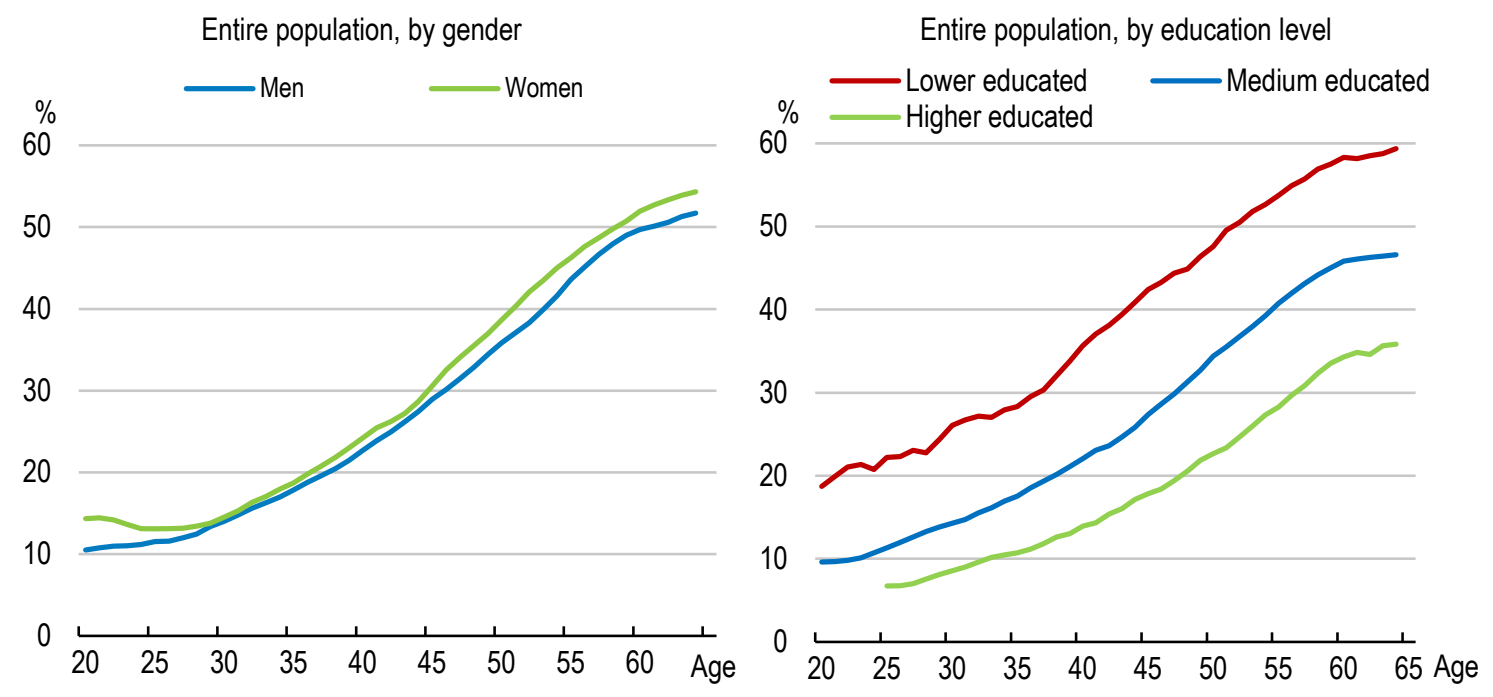

Note: "Low", "medium" and "high" levels of education correspond to International Standard Classification of Education (ISCED) codes 0-2, 3-4, and 5-6, respectively.

Source: OECD calculations from microdata on 24 OECD countries (OECD, 2017 $[1])$.

StatLink 제애 http://dx.doi.org/10.1787/888933973838

65. Promoting healthier lifestyles requires action both within and beyond the health sector. Curbing the major risk factors of smoking, alcohol consumption and obesity can reduce associated treatment costs. For example, alcohol prevention policies - such as brief general practitioner interventions, taxation, and regulations on advertising and drink-driving - have been shown to reduce costs compared to treating associated illnesses when they appear; and "sin taxes" on alcohol and tobacco reduce consumption of products harmful to health while also raising revenue that can be earmarked for health care (Pisu, 2014[59]; OECD, 2015 [60] $)$. More specific policies targeted at the elderly include promoting physical and cognitive exercise to prevent cognitive decline and physical frailty, addressing social isolation, and stopping infectious diseases among the elderly. Evidence is increasing on the cost-effectiveness of "reablement", which usually consists of a short-term intervention (3-12 weeks) in the home of an older person with a focus on training in daily functions instead of only compensatory care and assistance. For example, in Norway, reablement was found to be more cost-effective than usual care (Kjerstad and Tuntland, 2016 [61]).

66. There is significant scope to improve the efficiency of health care, as shown in a number of OECD studies (Joumard, André and Nicq, 2010 [62]; Hribernik and Kierzenkowski, 2013 ${ }_{[63]}$; Pisu, 2014 $[59]$; Lorenzoni et al., 2018 $8_{[64]}$; OECD, 2017 ${ }_{[65]}$. Efficiency savings could offset future spending pressures and help counteract the effect of ageing. Policies to contain health care costs and improve efficiency include the following:

- Budgetary caps, such as ceilings on overall (global) or sector (e.g. inpatient care) health expenditures, have had some success in containing health costs for example in Germany and the United Kingdom. In Germany, the imposition of a budget cap on drugs prescribed at the individual physician level resulted in an upsurge in the number of referrals and hospital admissions, presumably due to physicians 
referring their patients to other physicians or hospitals for fear of exceeding the ceiling. However, the additional costs in other sectors seem outweighed by the savings generated by the cap policy (OECD, 2015 $[60])$.

- Efforts to tackle wasteful spending, including spending on care that is at best ineffective or at worst harmful (e.g. over-prescription of antibiotics) as well as instances where the same benefits from care could be obtained at a lower cost - for instance by providing a service on an outpatient rather than an inpatient basis or by using generic rather than branded drugs. Changing the attitude and behaviours of patients and providers is often key to reducing these various types of wasteful spending, as well as improving coordination among providers and aligning financial incentives including provider payment methods (OECD, 2017 $\left.{ }_{[65]}\right)$.

- Moving away from volume-incentive payment methods (fee for service) could help contain the rising demand for and supply of health care services associated with rising incomes. Newer payment methods are geared towards improving value for money (OECD, 2016[66] $)$. They include "add-on payments", including pay-forperformance, whereby health care providers are rewarded for delivering more coordinated, safer and effective care (e.g. Portugal and Norway); "bundled payments", whereby payments for all services provided to a patient with a given medical problem are pooled together (e.g. England and Sweden); and "populationbased payments", whereby the payment covers most care needs of patients (e.g. Germany and Spain).

- More competition among health care providers, accompanied by strong and effective regulation, can curb spending growth and improve the quality of care. Regulated competition can strengthen incentives to achieve efficiency gains, better align health care service characteristics with patient preferences and promote access to care (with, for instance, means-tested subsidised insurance premiums). Strict regulation, enforcing quality standards and promoting access to care is, however, paramount to achieve these outcomes, as unfettered market forces are likely to lead to low-quality services because of asymmetric information, and to under-provision for the most vulnerable segments of the population because of their inability to pay. The introduction of market-oriented reforms in the English National Health Service in 2006, for example, seems to have had some success. GPs were required to offer patients a choice of provider for inpatient care, and providers started to be remunerated based on fixed prices. Hence, the reforms encouraged providers to compete for patients through improvements in quality of care. Hospital efficiency was found to improve in that better health outcomes were achieved in hospitals more exposed to competitive pressure, with lower average length-of-stay and no general increases in hospital expenditures (OECD, 2015[60]).

- Increasing the scope of goods and services covered by basic (primary) health care coverage can help achieve better value for money by increasing life expectancy and moderating health spending growth. Coverage expansion significantly increases patients' access to and use of preventive care, whereas less generous insurance coverage and an increased cost-sharing can discourage low-income and high-risk populations from seeking health care, with adverse consequences for health status and potentially higher spending in the future (Lorenzoni et al., 2018 $8_{[64]}$ ).

67. In many emerging countries, health insurance coverage is less developed, resulting in overall lower risk pooling and a large share of out-of-pocket payments. At the same time, emerging countries with fast population ageing and rising income per capita will face similar 
health care challenges as advanced countries, as the rising demand for better and more equitable services will result in higher health expenditure as a share of GDP (Pisu, 2014 ${ }_{[59]}$ ).

68. Emerging countries need both to extend their health care systems and adopt policies that will ensure their sustainability. Too high a reliance on out-of-pocket spending may render access to health care services inequitable and discourages the take-up of curative and preventive care, especially among the poor. Moreover, by reducing risk pooling, out-of-pocket spending results in a high risk of catastrophically high health expenditure for individuals. The launch of the comprehensive health insurance system in Indonesia in 2014 has had success in increasing coverage thanks to the subsidised component of the social insurance. An additional challenge for emerging countries is the potential adverse feedback loop between informality and social contributions, with widespread labour market informality making it difficult and expensive to collect contributions, which may eventually prevent the attainment of universal coverage, while high contribution rates foster informality.

\subsubsection{Financing models for long-term care}

69. As people get older, it becomes more likely that they will one day need help with day-to-day activities, i.e. long-term care. LTC needs are inherently unpredictable, can persist over many years and, in case of severe care needs, can far exceed typical incomes of retirees (Muir, $\left.2017_{[18]}\right)$. The unpredictability and potentially large costs suggest the need for risk pooling for LTC.

70. Most advanced economies provide some form of public risk pooling but the approaches vary widely. Some countries, such as the Nordics, have universal, tax-funded social care systems, which provide comprehensive coverage of LTC costs. Other countries have dedicated social insurance schemes, which can provide relatively comprehensive (e.g. the Netherlands and Japan) or partial (e.g. Korea and Germany) coverage of costs. A third group of countries (e.g. Italy) relies largely on cash benefits to support people with LTC needs. The United Kingdom and the United States both have means-tested, safety net systems, under which the poorest are fully covered but the wealthiest get little or no support. In contrast, in emerging and lower income countries, public risk pooling is often lacking and care provided through informal arrangements largely relies on unpaid family members.

71. One of the main challenges in the future will be to strike the right balance between providing appropriate social protection to people with LTC needs and ensuring that this protection is fiscally sustainable. Most advanced economies combine some form of universal coverage with targeting of care benefits according to the needs and means of beneficiaries. When designing cost-sharing and eligibility rules for LTC, countries need to look systematically at the level of protection provided to people in different scenarios. For many emerging economies the main challenge will be to build more formal risk pooling schemes. Raising contributions to finance these schemes is complicated due to the larger share of informality. Nevertheless, as care services are labour intensive and labour costs are relatively cheaper in emerging economies, costs of LTC provision may be lower.

72. Reducing the burden on declining working-age populations and ensuring sustainable financing will also require broadening of the contributions to LTC across revenue sources and inter-generationally. For example, Japan, the Netherlands, Belgium and Luxembourg complement payroll contributions with alternative revenues sources. In Japan and Germany, LTC premia are not only levied on the working-age population but also on retirees.

73. Given the ageing-related pressure on public finances, a stronger role of private LTC insurance may be desirable. Private LTC insurance, if effectively regulated, also holds 
potential to help individuals and families manage more effectively the risk of facing significant out-of-pocket LTC expenses, which can arise even in countries with public LTC coverage. However, the private LTC insurance market is small in most countries due to well-known market failures (e.g. adverse selection) and consumer myopia, and remain targeted at wealthier and higher income individuals. To encourage private insurance coverage, some countries provide tax incentives, but the evidence of their effectiveness is mixed (Colombo et al., 2011 $1_{[67]}$ ). In Germany, a compulsory private LTC insurance exists as an independent pillar of the compulsory LTC insurance system. In other countries, such as Singapore (Eldercare), enrolment into private insurance schemes is automatic with the possibility to opt-out of the scheme. In yet other countries, group insurance plays a significant role to supplement public coverage (e.g. France). Group insurance coverage typically takes place in the context of employment and has the advantage of encouraging early subscription into a private LTC insurance plan. Benefits for enrolees include the ability to negotiate better coverage solutions, as well as lower premia. For the insurance providers, group insurance mitigates the risk of adverse selection. However, countries relying on group insurance should pay attention to expanding coverage to the selfemployed and workers in non-traditional forms of employment. In some advanced economies, innovative private financing instruments such as LTC insurance as part of life insurance policies and reverse mortgages to draw on illiquid assets have also been used and can help manage outof-pocket costs.

74. Options to improve efficiency of LTC services (Colombo et al., 2011 $1_{[67]}$ ) include:

- A better targeting of benefits towards those with lower income and/or higher needs.

- Nearly all OECD countries have been encouraging home care, in order to limit institutional costs and satisfy people's preference for receiving care at home. They have done so through the direct expansion of home care supply, and the implementation of regulatory measures and financial incentives (e.g. cash benefits). However, some evidence suggests that home care may become more expensive than institutional care for severely disabled people. Another challenge is to ensure a sufficient supply of well-trained care workers (ILO/OECD, 2019 [28]).

- Efficiency gains might also be achieved by enabling choice and hence competition among private LTC providers, such as in the case of vouchers used in the Nordic countries. Policies to increase competition should be flanked by improved monitoring of the quality of private services provided.

- The introduction of new technologies could improve the productivity of LTC workers, but there is a dearth of evaluation of cost-effectiveness of many "smart" technologies and often technology appears useful as a supplement rather than a substitute of labour. Some evidence from the Netherlands and Norway suggests that cameras and sensors have reduced the number of emergency visits, freeing professionals to provide care elsewhere and reducing costs.

- Inefficiencies may arise from the interactions of the LTC system with the health care system. Several OECD countries have targeted the inappropriate use of acute health care services for LTC needs via financial measures, changes in administrative responsibilities and the introduction of information technology. Many OECD countries have attempted to co-ordinate or integrate health care and LTC services, but the difficulties faced are not trivial. The use of case managers, hospital at home and more geriatric expertise among health care professionals help improve coordination and reduce admissions to and time spent in hospitals. 
- The governance of LTC systems is complex and can lead to institutional inefficiencies. Various approaches could be adopted for improvement, such as establishing comprehensive information platforms, implementing evidence-based guidelines to support decision-making, introducing care planning programmes, sharing of information across government administrations and minimising costshifting incentives of providers.

\subsubsection{Adapting tax systems to deal with ageing pressures}

75. Ageing will put strain on tax systems by increasing spending on pensions, health and long-term care, as highlighted above, but also by exerting pressure on revenues: tax receipts tend to move with the employed population rather than the total population. For instance, microsimulations on Germany indicate that income tax revenue could decrease by around 7 per cent per year by 2035 compared to 2016, in spite of a higher labour market participation of the elderly (Beznoska and Hentze, 2017 $[68]$ ). At the same time, demographic change will induce shifts in the relative size of tax bases between labour, capital and consumption.

The design of tax systems may therefore need to be adapted to finance additional old-age spending and make up for the shortfall in revenues for other expenditure items, while ensuring a fair burden sharing across generations, above and beyond what can be achieved by raising employment rates. In most countries, the public financing of old-age incomes involves earnings-based schemes funded by contributions on labour (personal income and social security contributions) and safety net pensions funded by general tax revenue, but at times the shortfall in social contributions in PAYG systems has been made up for with general tax revenue. Taxes on labour already represent a high tax burden in many countries ( 
Figure 25); raising them further would in most instances discourage labour supply and thus growth, and put a disproportionate burden on younger generations. Other options then need to be envisaged, depending on each country's existing fiscal situation, to finance old-age spending without excessively crowding out productive expenditure and social spending on working-age people.

76. One option could be to shift the burden of financing the redistributive component of retirement schemes towards a heavier reliance on consumption taxes. Direct labour taxes are levied on a base that is set to shrink or grow more slowly than the overall population and directly create disincentives to labour supply, while indirect consumption taxes have a larger base including seniors and arguably entail less negative side effects. Countries where VAT or sales tax rates are relatively low and tax to GDP ratios are moderate (e.g. Australia, Canada, Korea, United States) could consider raising consumption taxation in order to finance old-age spending without sacrificing other productive spending. Japan is taking this direction given that part of the planned 2019 consumption tax hike is destined to fund pensions and longterm care. However, many other countries, particularly in Europe, have already exploited this avenue and may have reached the point - estimated at between 21 and $27 \%$ for standard VAT where further increasing value-added tax rates would actually decrease total tax receipts due to disincentives and tax avoidance effects (Akgun, Bartolini and Cournède, 2017 ${ }_{[69]}$ ) 
Figure 25. The tax mix in selected countries, 2016

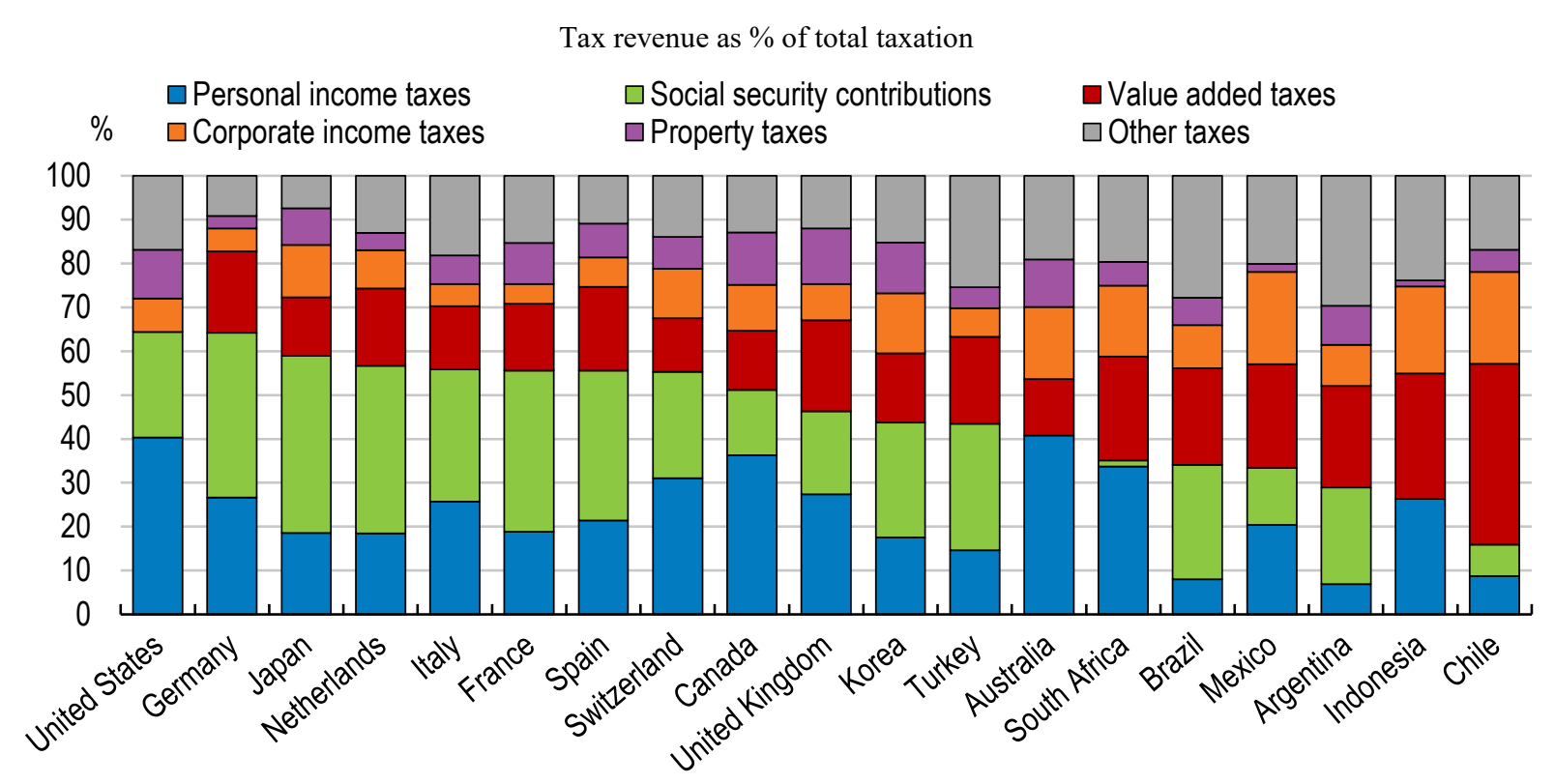

Note: Countries are sorted by the largest sum of personal income taxes and social security contributions. Source: OECD Revenue Statistics 2018.

StatLink त्ञाज http://dx.doi.org/10.1787/888933973857

77. For countries with a moderate overall tax burden but where standard consumption tax rates are already high, part of the response could still come from raising more tax revenue, focusing on taxes that are less distortive and/or have positive effects on inclusiveness. Removing regressive tax expenditures, such as VAT exemptions and reduced rates on hotels and restaurants that disproportionately benefit high earners, can help raise additional revenue at the same time as improving equity (OECD, 2018 $\left.8_{[70]}\right)$. In many countries, the base of capital income taxation could be broadened by increasing coherence in capital taxation across assets, thus improving efficiency in the allocation of savings. Shifting the tax mix towards a greater use of environmental taxation, including carbon taxes, is another potential option to raise substantial revenue without compromising efficiency, though the revenue from such taxes should be partly used to compensate low-income earners for possible regressive effects. Most countries have taxes in place that significantly price carbon emissions from road transport, but emissions from industry, electricity generation and the residential and commercial sectors go largely unpriced $\left(\mathrm{OECD}, 2016_{[71]}\right)$. There is also a case for re-examining inheritance taxes, which only amount to less than $0.4 \%$ of total taxation on average across the OECD, and can mitigate income and wealth inequality without detrimental effect on growth (Akgun, Cournède and Fournier, 2017 ${ }_{[72]}$ );

78. In countries with the highest overall tax burden (e.g. France, Nordic countries), priority should be given to targeting inefficient expenditures - i.e., spending with no proven benefits either growth or inclusiveness, for instance on public subsidies - to make room for rising ageing-related spending without adding to taxes on labour, capital and consumption. Expenditure restraint on non-ageing related spending, focused on reducing inefficient spending, can significantly mitigate the impact on consumption of financing pensions and care systems, compared to a situation where it would be achieved by tax hikes only (Cournède and Gonand, $\left.2006_{[73]}\right)$. 
79.

For many EMEs, a priority is to improve the revenue-generating capacity of the tax and social security system, including by combating informality and strengthening tax administration. In particular, avoiding high labour tax wedges on low-paid workers, who are at the highest risk of working in the informal economy, can improve incentives to formalise. Changes to tax policies can be complemented by tax administration measures including targeted audits, simplified worker registration, and the use of indirect methods to ascertain tax liability (OECD, 2018[70]).

80. At the same time, tax policy can contribute to increase fertility, to the extent it helps reduce the barriers to family formation so that parents can have as many children as they desire, while also encouraging female participation in the labour market. Together with childcare and early education policies, tax policy can help reduce the direct cost of larger families that can lead parents to delay or forgo having more children (OECD, 2011 [74]). Empirical studies indicate that the effects of family income splitting for income tax, such as the French "quotient familial" (Egger and Radulescu, 2009 $9_{[75]}$ ), and child-related cash transfers (Laroque and Salanié, 2014 [76]; Boccuzzo et al., 2008 [77] $)$ on fertility are positive, though modest. Child-related financial support tends to have an impact by accelerating the timing of births, especially for low-income families, and increasing the prevalence of families with more than one child $\left(\mathrm{OECD}, 2011_{[74]}\right)$. However, the design of child-related benefits should be mindful of possible unintended effects on female labour force participation, as family income taxation may imply high marginal tax rates on second earners and home care cash benefits may discourage lower income mothers from staying in the labour force. Tax credits or subsidies for bought-in childcare services yield the double benefit of increasing both female labour supply and fertility, especially if they are part of a wider package to help reconcile work and family commitments (including availability of formal childcare, flexible workplace practices and parental leave arrangements).

81. Even countries that have not yet reached the stage of rapid ageing may have an interest in engaging in tax reforms early to prepare for the fiscal pressures to come. Given that the relative size of tax bases is expected to change, some changes in tax design may have more impact and be more politically feasible if done earlier rather than later. For instance, a shift from labour taxes to consumption taxes may become less and less popular among the electorate as the median voter ages (see Box 2). Conversely, if some countries have scope to increase social contributions, it may be better not to wait to do so until labour becomes scarcer and the associated tax base shrinks. In general, the distributional effects of tax reforms within and between generations will need to be considered along with their impact on revenue generation and growth.

\subsubsection{Fostering financial literacy and financial inclusion}

82. People are set to become more involved in making individualised choices for their retirement arrangements, and the reliance on own savings and assets to fund old-age expenses is likely to increase. Understanding financial concepts, making informed and autonomous decisions will be essential to avoid poverty in retirement. Yet, a majority of people do not have basic financial literacy in many G20 countries. Less than $50 \%$ of adults could on average answer $70 \%$ of financial knowledge questions correctly across G20 countries, ranging from $62 \%$ in Korea to $31 \%$ in South Africa (Figure 26). Significant gender differences can also be observed in most countries, with men more likely to achieve basic financial knowledge than women. This gender gap is particularly concerning given that women are more exposed to the risk of old age poverty, and their longer average life expectancy makes adequate retirement planning all the more crucial.

83. Financial illiteracy is particularly a concern when planning for retirement. Across G20 economies, only about $60 \%$ of households on average are using a budget (OECD, 2016 $[78]$ ). 
Adults have also difficulties to set long-term goals and strive to achieve them. Raising savings could help people smooth income over the long run and make them more resilient to financial shocks, but active savers are still relatively few in a number of countries such as Brazil or South Africa. The great majority of adults know of at least five financial products but may not be sufficiently informed about their complexity (OECD, 2017[79]). These financial behaviours raise the risk of underestimating future financial needs, accumulating insufficient savings or picking inadequate financial investments.

84. There is therefore considerable scope for improvement in financial literacy. It is important to consider building good habits from childhood to make sure that the next generation acquires relevant financial knowledge. Basic financial concepts such as interest compounding or applied numeracy need to be strengthened across the population, especially for women, and could be made part of core education curricula. ${ }^{7}$

Figure 26. Many people do not have basic financial literacy, especially women

$\%$ of respondents achieving the minimum target score on financial knowledge

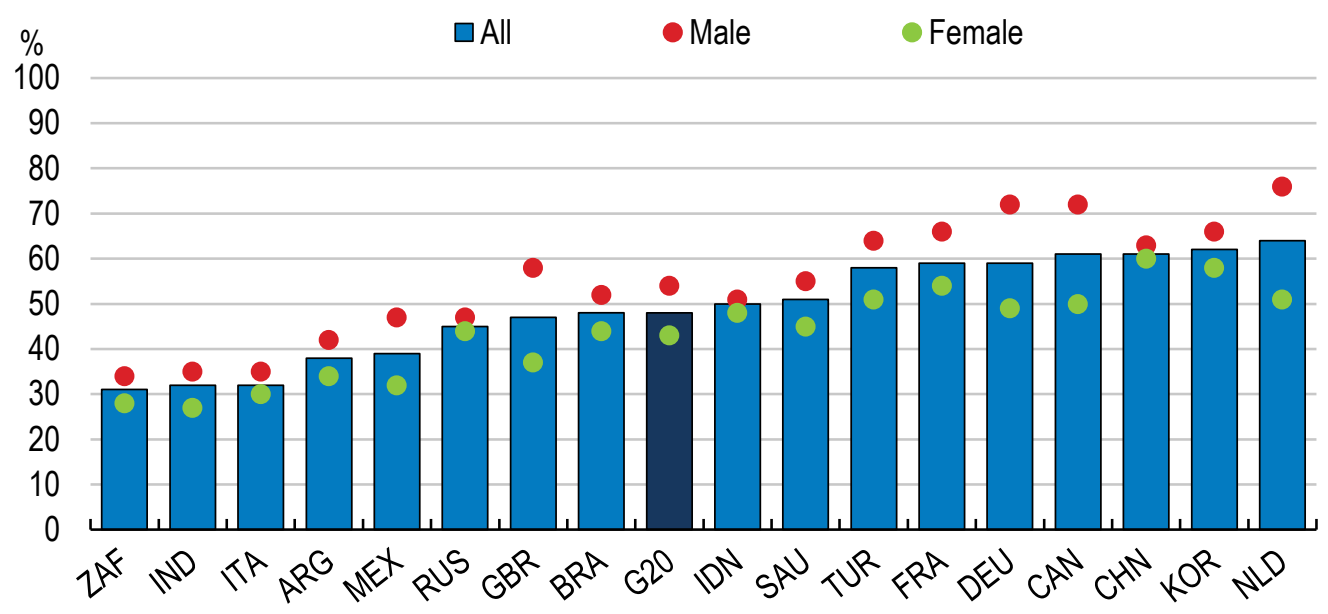

Note: The minimum target score is reached when answering $70 \%$ of the financial knowledge questions correctly. G20 is the simple average of the country percentages for all G20 countries with comparable data. G20 countries that are excluded from this figure do not have comparable data.

Source: G20/OECD INFE report on adult financial literacy in G20 countries.

StatLink त्गाड़ http://dx.doi.org/10.1787/888933973876

85. As longevity improves, it is vital to encourage appropriate financial behaviours like budgeting and long-term planning. Governments could for instance promote the use of digital tools that help consumers, households and businesses improve their overall financial management $\left(\mathrm{OECD}, 2017_{[80]}\right)$. Moreover, detailed and impartial information on financial products should be made easily accessible to people, and regulators should ensure that professional financial advice is affordable as well as transparent about potential conflicts of interest (OECD,

${ }^{7}$ A National Strategy for Financial Education is an effective way of doing this, as indicated in the OECD/INFE High-level Principles on National Strategies for Financial Education, endorsed by G20 Leaders in 2012. G20 members have further recognised the importance of enhancing financial literacy in the 2017 Hamburg Action Plan, emphasising "the importance of enhancing financial literacy and consumer protection given the sophistication of financial markets and increased access to financial products in a digital world". 
$\left.2016_{[39]}\right)$. At the same time, it is important to provide guidance to consumers, for example on using credit responsibly. Regulation and consumer protection frameworks should therefore be combined with financial education to improve people's financial resilience.

\subsection{Lifting employment and productivity in ageing societies}

\subsubsection{Extending working lives}

86. Workers can be encouraged to stay employed longer and given the means to do so in good conditions by tackling barriers to older workers' employment and flexible retirement, within and outside the pension system. ${ }^{8}$ The labour supply of older workers responds to built-in incentives in pension schemes, although more structural trends account for a large part of the observed increase in their participation rate (Box 3).

87.

Even though pension design is crucial to enable longer working lives, barriers to phased retirement also lie outside the pension system. Many pension systems currently allow some form of flexible retirement, but the take-up of such schemes remains low; combining work with receiving a partial pension in countries where it is permitted is also rare. Nearly three in five workers globally envisage a transition to retirement where they either work part-time before or in retirement, or continue working as they currently do past retirement age (Aegon, $2018_{[33]}$. However, only a minority of employers appear to offer older workers these options. Only about $40 \%$ of employers offer flexible time schedules in the United States, while in Europe nearly $80 \%$ of people over 55 cite a lack of opportunities to gradually retire by reducing hours worked as an important reason to stop working altogether $\left(\mathrm{OECD}, 2017_{[17]}\right)$. In a number of countries, firms retain the right to set a mandatory retirement age. The minimum age at which they can do so has been raised in recent years in Japan, Korea and France, but governments could consider abolishing the practice of mandatory retirement set by firms or collective agreements, while reforming employment rules where necessary to provide employers with greater flexibility to dismiss poorly performing workers. The public sector should lead the way by curtailing the use of mandatory retirement at a certain age for civil servants.

88. Governments can encourage firms to hire and retain older workers through regulation, employer guidelines and information campaigns. Flexible working hours and workplaces help respond to ageing of the workforce, including through teleworking arrangements that make it easier for family caregivers to remain in the active workforce. For instance in Canada, under the Employment Relations (Flexible Working Arrangements) Amendment Act of 2007, all employees with caring responsibilities have the right to request flexible working arrangements. In England, the Care Act 2014 placed new duties on local authorities to assess and support adult carers to maintain or re-enter employment and training, for example by helping to ensure that the person they care for is looked after while they are at work. Promoting age-friendly businesses also involves developing more flexible models for careers, and ensuring that working environments are adapted to older workers with health issues or disabilities. Adopting specific equipment, such as to compensate for hearing or visual impairments, and providing adapted, less physically demanding jobs for old workers increases the relative productivity of senior workers (Göbel and Zwick, 2013 ${ }_{[81]}$ ). The European Healthy Workplaces Campaigns provide an interesting example to build awareness.

\footnotetext{
${ }^{8}$ See the OECD Council Recommendation on Ageing and Employment Policies.
} 


\section{Box 3. Pension design and labour supply of older workers}

After decades of decline, there has been a remarkable turnaround in the participation rate of older people in almost all OECD countries since the turn of the century. Were this trend to continue, it could offset some of the negative contribution that population ageing is projected to make to labour supply growth. Understanding the reasons behind the uptrend in participation rates at older ages, and especially the contribution of public policies to this trend, is important to inform policymaking going forward. Recent OECD analysis examines the factors behind the evolution of participation rates for 55-to-74 year-olds in 24 European OECD economies as well as the United States, Canada and Japan (Geppert et al., 2019 $\left.{ }_{[49]}\right)$. The main findings are:

- Raising both the minimum and normal retirement ages by one year increases the participation rate of 55 -to- 74 year-olds by $3 / 4$ percentage point in the median country, in line with previous studies.

- The median increase in participation rates of 55-to-74 year-olds between 2002 and 2017 was 10.9 percentage points. More than two thirds of this increase can be attributed to rising life expectancy and educational attainment. About 1 percentage point is attributable to changes in statutory retirement ages, although part of the reason these effects are not larger is that in most countries, statutory retirement ages have not kept pace with life expectancy.

- Evidence of falling disability pension rolls and reduced sensitivity of old-age participation to the level of unemployment suggests that the tightening of alternative early retirement pathways through unemployment or disability schemes has been a major factor in the turnaround in the participation rate of older workers.

- Participation rates for 55-to-74 year-olds are projected to keep rising through 2030, by 3.4 percentage points for the median country. Rising life expectancy and educational attainment are projected to make the largest contributions, more than compensating for the negative contribution of population ageing in most countries.

- If age-specific participation rates remained stable at current levels, ageing populations would lower GDP per capita in the median OECD country by $5 \frac{1}{2}$ per cent by 2030. Relative to this artificial baseline, projected increases in old-age participation rates offset some, but not all of these losses: 3 percentage points in the median country, but as much as 5-6 percentage points in Spain, Greece and Italy if current unemployment gaps close as assumed. In most countries, only a small share of these gains are driven by planned pension system reforms, but as much as $1 / 2$ percentage point in Denmark and the United Kingdom, and $3 / 4$ percentage point in Italy, given legislation that ties the evolution of retirement ages to life expectancy in these countries.

- In countries that are not planning any future increase in statutory retirement ages, raising them by two thirds of the projected increase in life expectancy could add up to 1-1.4 percentage points to the participation rate of 55-to-74 year-olds by 2030 . 
89.

In some instances, tackling objective barriers to retaining older workers may involve measures to better align the age productivity and wage profiles in collective bargaining agreements. Seniority wage setting in collective bargaining agreements or insufficiently flexible wages can make older workers relatively costly to hire compared to how productive they are, as older workers productivity may decline at old age for repetitive tasks or for health-related reasons. To further incentivise companies to hire the most vulnerable older workers, a number of countries have introduced wage-subsidy and in-work benefit schemes targeted at senior workers (e.g. Australia). Overall, a package of placement, training and counselling measures targeted at disadvantaged older workers may be more effective than wage subsidies alone.

\subsubsection{Ensuring that older workers' skills remain well adapted to labour market needs}

90. Effectively extending working lives requires addressing concerns about the lack of employment opportunities for older workers, so that later retirement age does not mean longer unemployment spells for older people, especially the lower-skilled. When displaced, older and long-tenure workers typically are at the greatest risk of ending up in long-term unemployment or finding jobs that are less well paid than their previous jobs in OECD countries. There are also strong disparities in labour market opportunities among older workers. Most highly-educated senior workers are employed until they retire (see Figure 6), but less educated senior workers are much more likely to retire after spells of inactivity, including for health reasons. Low-educated people are overall more likely to retire when they reach the retirement age, whereas highereducated people tend to work longer and are more likely to experience phased or partial retirement.

91. Ensuring that older workers remain employable and productive requires closing the age gap in digital technology proficiency. Digital technologies, while holding promise for greater productivity, can accelerate skill obsolescence and make the elderly less employable. Many older people exhibit lower levels of digital readiness than their children and grandchildren, and also participate less in job-related training than younger workers (Figure 27). For instance, data from the OECD Survey of Adult Skills shows that on average across the 22 participating countries, a third of 55-to-65 year-olds have no computer experience or fail core ICT tests, and only about a quarter use email or Internet at work daily while nearly half of primeage workers do so. The age gap in the use of digital technologies increases with their complexity. As a result, while the risk of unemployment tends to be lower in technology-intensive occupations, older workers are less likely to work in them than their prime-age peers. Moreover, in technology-intense occupations, older workers are particularly exposed to lay-offs. During the crisis period (2008-2012), older workers were almost three times more likely to have lost their job than younger workers in these technology-intense occupations, twice the gap observed in low-tech occupations (OECD, 2017 $\left.{ }_{[1]}\right)$. 
Figure 27. Older workers lack IT skills, but participate less in training

Workers reporting lack of computer skills to do their job well, 2012

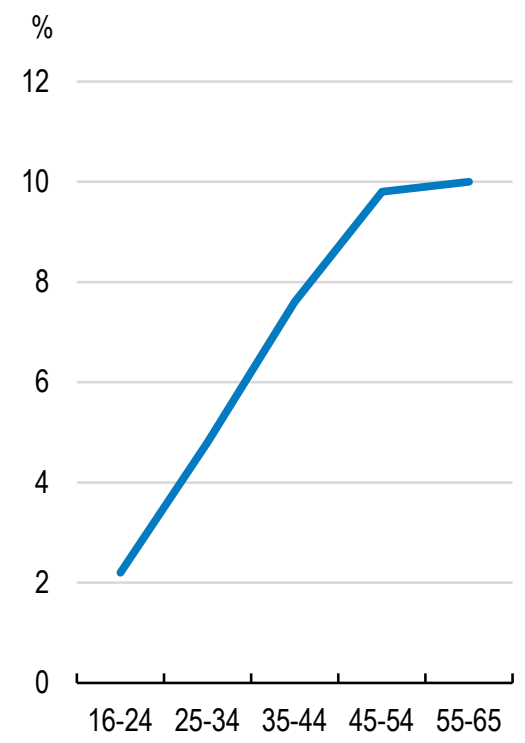

Participation in training $\%$ of all employed in each age group, 2012

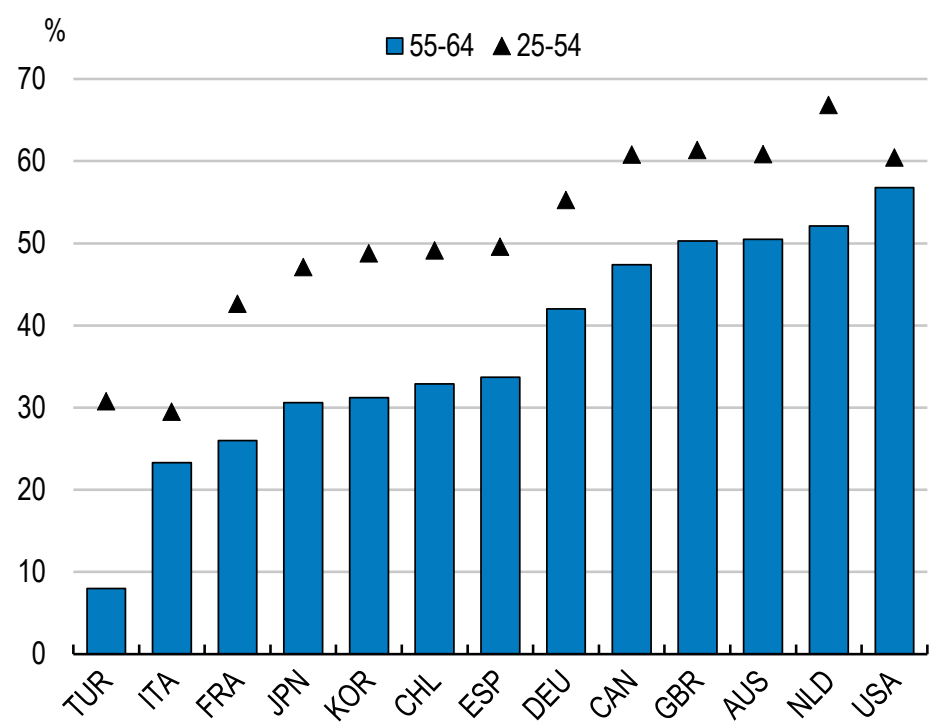

Note: Left: average of 22 OECD economies. Right: Job-related training during year prior to the survey in 2012. The OECD average from PIAAC excludes Hungary, Iceland, Latvia, Luxembourg, Mexico, Portugal and Switzerland.

Source: OECD estimations from the OECD Survey of Adult Skills (PIAAC).

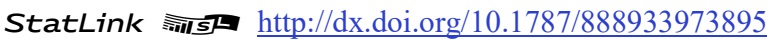

92.

If people are to extend their working lives, they must have access to effective skills development throughout their life to enable them to update and upgrade their skills according to changing labour market needs. Lifelong learning programmes for older workers should be designed to strengthen the skills required to perform non-routine jobs and to address the skills needs of technology-intensive occupations in the digital economy. Firms tend to underinvest in the training of older workers, as older workers will eventually retire and companies do not take into account the full social return of keeping senior workers active and productive. These market failures in the provision of job-related training create a rationale for policy-makers to provide financial support for lifelong learning, or incentivise it through paid training leave schemes. For instance in Germany, the WeGeBAU programme provides subsidies for wages and training costs to encourage firms to train the low-skilled and workers over 45; Australia is scaling up skills assessment and guidance for workers over 50 through its Career Transition Assistance programme; and Korea provides vouchers to buy approved training courses for workers over 40, non-regular workers and SME employees willing to undertake training on their own initiative. Higher retirement age and public financial support for lifelong learning may improve the perceived cost-benefit balance of training both for employers and employees, but policy should also ensure that adult training is adapted to the needs of workers approaching the end of their careers. This can include providing short courses directly tied to specific tasks and jobs, focusing less on foundation skills and more on practical, directly relevant work issues.

93. Obtaining the recognition of skills acquired through experience is particularly valuable for older workers whose qualifications may be otherwise outdated. Procedures to assess and validate skills and competencies acquired on the job help make skills transparent to 
prospective employers, thus improving the employability of older workers. For instance in the Netherlands, the Ervaringscertificaat (Experience Certificate) serves to validate acquired experience; it is included as part of collective labour agreements in several sectors, and is paid for by a number of training and development funds.

\subsubsection{Expanding the labour supply of low-skilled workers, women and youth}

94. The effects of ageing on dependency ratios can be mitigated by measures to expand the labour force participation of other population groups. Investing in access and quality of education and training, from early schooling to higher education and lifelong learning, raises effective labour supply as more highly skilled workers are more productive and have higher employment rates. Measures to tackle skills mismatch improve the aggregate productivity of a given pool of workers, including through easing stringent product and service market regulation and restrictive housing policies. Encouraging the formalisation of more jobs in EMEs can also improve the sustainability and adequacy of pension systems. Recent reforms have taken steps in this direction in some countries, notably through reforming job protection for formal workers where it is excessively strict and reducing the high taxation of labour (OECD, $\left.2019_{[82]}\right)$.

95. A higher proportion of working women can help contain the rise in dependency ratios at the same time as contribute to reducing old-age poverty risk, which disproportionately affect elderly women. While female labour force participation remains below that of men, younger generations of women are gradually narrowing the gap (Figure 28). Several factors can explain this phenomenon: rising educational attainment among women, the expansion of the services sector and of part-time employment, and changing social norms, which have led to lower and delayed fertility and greater acceptance of non-parental childcare. Policy changes have also contributed to this trend in OECD countries, notably the expansion of formal childcare for children below three (Thévenon, 2013 $3_{[83]}$ ). In addition, policies aimed at reconciling work and family life have also a positive, but limited, effect on fertility rates which could in turn contribute to reduce the dependency ratios (OECD, 2011 $\left[1^{77]}\right]$ ). In Germany and Japan for instance, childcare provision was recently scaled up, and Japan reduced the distortive spousal deduction in personal income tax in 2018 (OECD, 2018 [84]; OECD, 2017 [85]; OECD, 2019 $\left.{ }_{[86]}\right)$. Yet the challenge to narrow participation gaps remains relevant in many countries. Further progress needs to be made on the G20 Brisbane commitment to reduce the gender gap in labour force participation rates by $25 \%$ by 2025 . A better provision of affordable childcare for children below three and childfriendly employment arrangements is key to close gender gaps. Efforts to raise the supply of formal long-term care would help reduce the burden from taking care of the elderly on formal work participation, which disproportionately falls on women. Many countries also have scope to remove disincentives to work for second earners in the design of tax and benefit systems, such as tax allowances for non-working spouses and systems of joint taxation. 
Figure 28. The gender gap in employment rates has been reduced, but remains high in some countries

Difference in employment rates (employment to the population aged 15-64 years old) between men and women, percentage points

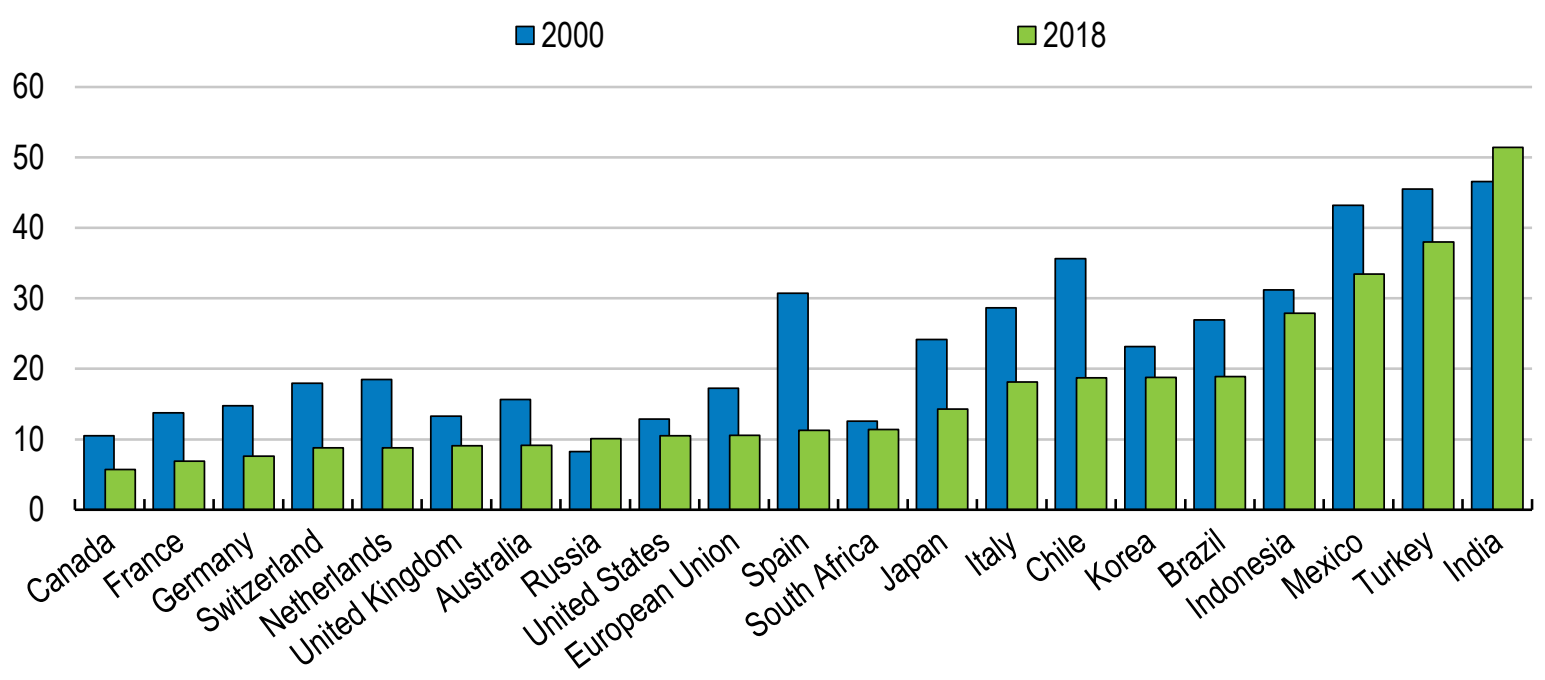

Source: OECD Labour Force Statistics.

StatLink ज्ञाs http://dx.doi.org/10.1787/888933973914

96. Promoting a good start for the youth in their working lives can yield the double benefit of increasing employment rates and fighting life-long inequalities that build up early in life, resulting in old-age poverty decades later. Policies to enhance skills and labour market inclusion of the youth include providing sufficient employment orientation, especially to those who cannot draw on social support networks, strengthening vocational education, and designing effective labour market policies to connect youths not in employment, education or training with jobs. As young people often start their working lives in non-standard work arrangements, policies should aim to ensure that short-term entry jobs serve as stepping stones to more stable jobs. Apprenticeships combining on-the-job training and classroom learning can help to facilitate successful school-to-work transitions.

\subsubsection{Can migration be a solution?}

97. Well-managed migration has the potential to make positive demographic, economic and social contributions to both countries of origin and destination. Between 2005 and 2015 , migrants accounted for $65 \%$ of the increase in the workforce in the United States and $92 \%$ in the EU (OECD/ILO/IOM/UNHCR, 2018 $\left.{ }_{[9]}\right)$. The share of migrants in the total G20 population remains small, at $3.5 \%$, and the scale of immigration needed to offset the effects of population ageing on the workforce would be difficult to manage socially and politically. However, migration can help to address skills mismatches and specific labour market needs, for example in long-term care, and contribute to build the talent pool.

98. All G20 countries have some channel for admitting foreign workers to address skill shortages, even if policy settings vary widely. Some traditional settlement countries, notably Australia and Canada, have developed sophisticated merit-based migration systems to select skilled migrants in their permanent migration programmes. Candidates for migration are pre- 
screened based on multiple criteria to enter a pool from which people are picked by national authorities or various authorised sponsors (including employers in some cases). Designing an efficient points system takes time and should be built on evidence that explains what makes migrants succeed in the labour market.

99. Many G20 countries manage labour migration, including in some cases for lesser skilled migration, through temporary migration schemes. For instance, Japan has recently passed legislation to allow in foreign nationals to fill vacancies in industries most hit by shortages, such as long-term care and construction. The bulk of OECD countries admit labour migrants only, or mostly, with a job offer in hand (OECD, 2014 $\left.{ }_{[87]}\right)$. There are a number of tools to help countries aiming to access international talent. Labour market analyses can help identify occupations and sectors where international recruitment can be facilitated. Pools of candidates can be selected either through the public infrastructure or private agencies. However, it remains difficult to match the demand for skills in destination countries with the potential supply. A common challenge is verifying that foreign workers possess the right set of skills to meet the demand in the destination country.

100. If receiving countries adapt migration policies to scale up skilled labour migration, this can encourage brain drain from low and middle-income countries. To the extent possible, sending and receiving economies should adopt coordinated approaches to encourage mutually beneficial flows of workers. This includes facilitating circular flows so that the human and financial capital gained by migrants in the host country also benefits the host country; as well as programmes by which receiving countries invest in skills in sending countries. Skills Mobility Partnerships in particular have recently emerged as an innovative way to associate migration and skills development for the mutual benefit of origin and destination countries, with training costs shared between all parties involved (OECD/ILO/IOM/UNHCR, 2018 $\left.{ }_{[9]}\right)$.

101. Receiving countries should step up efforts to enhance the labour market inclusion of migrants already present in their territories, and make full use of their skill set. More than one third of tertiary-educated migrants in G20 countries for which data are available are overqualified for their jobs, and migrant workers are also more likely to end up in non-standard employment (OECD/ILO/IOM/UNHCR, 2018 $\left.8_{[9]}\right)$. A step forward taken by the European Commission has been to develop a skills profile tool to support early identification of the skills and work experience of migrants and to provide guidance on training, education or employment (OECD, 2018 $\left.{ }_{[88]}\right)$. More broadly, bilateral and multilateral agreements on the assessment and recognition of foreign qualifications are an efficient way to improve skills mobility while saving time and resources, but are still rare $($ OECD, 2017 $[89])$.

102. Refugees face particularly high hurdles in their labour market integration, more so than those who migrate for labour, study or family reasons. Lessons learned from specific programmes to help refugees suggest that improving skills development and recognition of prior learning are key to facilitate labour market access (ILO, 2018 ${ }_{[90]}$ ). To help realise the potential economic gains from refugees, integration policy should focus on scaling up language training, as well as providing information and coaching to address potential information barriers about the labour market. For instance, Germany has put in place since 2016 preparatory courses for on-thejob vocational training for refugees with good prospects of staying in the country. 


\subsubsection{Leveraging the "silver economy" for entrepreneurship and innovation}

103. The "silver economy"9 can be a powerful source of new products, services and jobs where policies encourage entrepreneurship and innovation. Population ageing can create new markets and opportunities for innovators to respond to unmet needs, in order to address the challenges of physical and cognitive impairments for the elderly but also the rising demand for leisure and services by retirees in good health. People over 60 are on track to generate more than half of urban consumption growth in developed economies, fuelled by spending on healthcare but also transport, housing and entertainment (Irving, Beamish and Burstein, 2018 [91] $)$.

104. Innovations can help the elderly remain healthier, more autonomous and age in their own homes. For instance, telemedicine and mobile clinics can help improve health care in underserved areas, while home-based health monitoring through smart devices and wearable technologies communicating with health professionals can enable more personalised care (OECD, 2014 $\left.{ }_{[92]}\right)$. Data-driven innovation could provide practical solutions to enhance elderly people's quality of life and facilitate independent living, while reducing financial costs and freeing up time for family caregivers to continue participating in the labour market. Advances in robotics (e.g. development of "carebots" in Japan), intelligent sensors (e.g. fall detection) and neuroscience are particularly likely to meet a rising demand, as well as voice-activated technologies and autonomous vehicles. Regulation should ensure appropriate data privacy and security, as well as greater interoperability across devices, services and systems in order to foster the emergence of connected healthcare systems.

105. At the same time, senior entrepreneurship could be an integral part of a longer productive participation of older workers in the labour market. Senior entrepreneurs start businesses not only for lack of alternative employment, but in most cases to supplement retirement income, to respond to perceived opportunities or as a path to keeping an active and socially engaged life (Global Entrepreneurship Monitor, 2017 [93] . Older people can leverage their experience and knowledge into successful ventures, and tend to have more developed networks, more financial resources, management experience and accumulated social capital than younger entrepreneurs. However, they also face significant barriers in the form of lack of IT skills, access to early stage finance, insufficient information on starting and running a business, as well as potential age discrimination. Subsidised tailored short courses or specific mentoring programmes to help senior entrepreneurs gain the necessary IT skills to start new ventures and acquire knowledge on the practicalities on building businesses could also support active and productive ageing. Allowing older people to cumulate unemployment benefits or partial pensions with entrepreneurial activities can help counter the reduced tolerance for financial risk of older entrepreneurs.

106. More generally, countries that put in place the right conditions for innovation and entrepreneurship to thrive will be best equipped to benefit from the silver economy. Policies to that effect include tackling regulatory and administrative barriers to starting businesses, maintaining adequate regimes for the protection of intellectual property, and ensuring that competition regulation is conducive to innovation and business dynamism.

\footnotetext{
${ }^{9}$ The silver economy can be understood as an environment in which the over 60 s interact and thrive in the workplace, engage in innovative enterprise, help drive the marketplaces as consumers and lead healthy, active and productive lives (OECD, 2014 [92]). Alternatively, the silver economy can be defined as the economic opportunities arising from the public and consumer expenditure related to population ageing and the specific needs of the population over 50" (European Commission, $2015_{[95]) \text {. }}$
} 


\section{References}

Abeliansky, A. and K. Prettner (2017), "Automation and Demographic Change”, $C E G E$ Discussion papers, No. 310, http://wwwuser.gwdg.de/ cege/Diskussionspapiere/DP310.pdf.

Acemoglu, D. and P. Restrepo (2018), "Demographics and Automation", NBER Working Paper, No. 24421, http://dx.doi.org/10.3386/w24421.

Acemoglu, D. and P. Restrepo (2017), "Secular Stagnation? The Effect of Aging on Economic Growth in the Age of Automation", American Economic Review: Papers \& Proceedings, Vol. 107/5, pp. 174-179, http://dx.doi.org/10.1257/aer.p20171101.

Aegon (2018), The New Social Contract: A blueprint for retirement in the 21st century. The Aegon Retirement Readiness Survey 2018, Center for Longevity and Retirement, https://www.aegon.com/contentassets/6724d008b6e14fa1a4cedb41811f748a/retirementreadiness-survey-2018.pdf.

Akgun, O., D. Bartolini and B. Cournède (2017), "The capacity of governments to raise taxes", OECD Economics Department Working Papers, No. 1407, OECD Publishing, Paris, https://dx.doi.org/10.1787/6bee2df9-en.

Akgun, O., B. Cournède and J. Fournier (2017), "The effects of the tax mix on inequality and growth", OECD Economics Department Working Papers, No. 1447, OECD Publishing, Paris, https://dx.doi.org/10.1787/c57eaa14-en.

Aksoy, Y. et al. (2019), "Demographic Structure and Macroeconomic Trends", American Economic Journal: Macroeconomics, Vol. 11/1, pp. 193-222, https://www.aeaweb.org/articles?id=10.1257/mac.20170114\&\&from=f.

Beetsma, R., W. Romp and R. Van Maurik (2017), "What Drives Pension Reform Measures in the OECD? Evidence based on a New Comprehensive Dataset and Theory", CEPR Discussion Paper No. 12313, https://cepr.org/active/publications/discussion_papers/dp.php?dpno=12313.

Beznoska, M. and T. Hentze (2017), "Demographic change and income tax revenue in Germany: [68] a microsimulation approach", Public Sector Economics, Vol. 41/1, pp. 71-84, http://dx.doi.org/10.3326/pse.41.1.

Boccuzzo, G. et al. (2008), "The Impact of the Bonus at Birth on Reproductive Behaviour in a Lowest-low Fertility Context: Friuli-Venezia Giulia (Italy) from 1989 to 2005”, Vienna Yearbook of Population research, pp. 125-148.

Caldera Sánchez, A., A. de Serres and N. Yashiro (2016), "Reforming in a difficult macroeconomic context: A review of the issues and recent literature", OECD Economics Department Working Papers, No. 1297, OECD Publishing, Paris, https://dx.doi.org/10.1787/5jlzgj45b3q0-en. 
Carvalho, C., A. Ferrero and F. Nechio (2016), "Demographics and real interest rates: Inspecting the mechanism", European Economic Review, Vol. 88, pp. 208-226, http://dx.doi.org/10.1016/j.euroecorev.2016.04.002.

Casamatta, G. and L. Batté (2016), "The Political Economy of Population Aging”, in Piggott, J. (ed.), Handbook of the Economics of Population Ageing, North-Holland, http://dx.doi.org/10.1016/bs.hespa.2016.07.001.

Colombo, F. et al. (2011), Help Wanted?: Providing and Paying for Long-Term Care, OECD Health Policy Studies, OECD Publishing, Paris, https://dx.doi.org/10.1787/9789264097759en.

Cournède, B. and F. Gonand (2006), "Restoring Fiscal Sustainability in the Euro Area: Raise Taxes or Curb Spending?", OECD Economics Department Working Papers, No. 520, OECD Publishing, Paris, https://dx.doi.org/10.1787/414711615127.

De la Maisonneuve, C. et al. (2016), "The drivers of public health spending: Integrating policies and institutions", OECD Economics Department Working Papers, No. 1283, OECD Publishing, Paris, http://dx.doi.org/10.1787/5jm2f76rnhkj-en.

De La Maisonneuve, C. and J. Oliveira Martins (2015), "The future of health and long-term care spending", OECD Journal: Economic Studies, Vol. 2014/1, https://doi.org/10.1787/eco studies-2014-5jz0v44s66nw.

Delgado, G. et al. (2007), "Avaliação do Simples: Implicações à Formalização Previdenciária”, Instituto de Pesquisa Econômica Aplicada, No. TD 1277, http://www.ipea.gov.br/portal/index.php?option=com_content\&view=article\&id=4531.

Egger, P. and D. Radulescu (2009), "Family Income Splitting and the Number of Children: Evidence from a Natural Experiment", CESifo Area Conference on Public Sector Economics, Munich, http://www.cesifogroup.de/dms/ifodoc/docs/Akad_Conf/CFP_CONF/CFP_CONF_2009/Conf-pse09vanderPloeg/Conf-pse09-papers/pse09 Radulescu 9455479 en.pdf.

Eggertsson, G., M. Lancastre and L. Summers (2018), “Aging, Output Per Capita and Secular Stagnation", NBER Working Paper, No. 24902, http://dx.doi.org/10.3386/w24902.

European Commission (2018), The 2018 Ageing Report: Economic and Budgetary Projections for the EU Member States (2016-2070), http://dx.doi.org/10.2765/615631.

European Commission (2015), Growing the European Silver Economy, http://ec.europa.eu/research/innovation-union/pdf/active-healthy-ageing/silvereco.pdf.

Fall, F. et al. (2014), "Vulnerability of Social Institutions", OECD Economic Policy Papers, No. 11, https://doi.org/10.1787/5jz158r4q0zn-en.

Gagnon, E., B. Johannsen and D. Lopez-Salido (2016), "Understanding the New Normal: The Role of Demographics", FEDS Working Paper No. 2016-080, http://dx.doi.org/10.17016/FEDS.2016.080. 
Geppert, C. et al. (2019), "Labour supply of older people in advanced economies: the impact of changes to statutory retirement ages", OECD Economics Department Working Papers, No. 1554, OECD Publishing, Paris, https://dx.doi.org/10.1787/b9f8d292-en.

Ghilarducci, T. (2018), "Workplace Retirement Coverage Drops And The System Continues To Fail", Forbes.

Global Entrepreneurship Monitor (2017), Global Entrepreneurship Monitor Special topic report 2016-2017: Senior Entrepreneurship, https://gemconsortium.org/report/gem-2016-2017report-on-senior-entrepreneurship.

Göbel, C. and T. Zwick (2013), "Are personnel measures effective in increasing productivity of old workers?”, Labour Economics, Vol. 22, pp. 80-93.

Goodhart, C. and M. Pradhan (2017), "Demographics will reverse three multi-decade global trends", BIS Working Papers, No. 656, https://www.bis.org/publ/work656.pdf.

Guillemette, Y. and D. Turner (2018), "The Long View: Scenarios for the World Economy to 2060", OECD Economic Policy Papers, No. 22, OECD Publishing, Paris, http://dx.doi.org/10.1787/b4f4e03e-en.

Hribernik, M. and R. Kierzenkowski (2013), "Assessing the Efficiency of Welfare Spending in Slovenia with Data Envelopment Analysis", OECD Economics Department Working Papers, No. 1058, OECD Publishing, Paris, https://dx.doi.org/10.1787/5k44v5373q0q-en.

Ikeda, D. and M. Saito (2014), "The effects of demographic changes on the real interest rate in Japan", Japan and the World Economy, Vol. 32, pp. 37-48, http://dx.doi.org/10.1016/j.japwor.2014.07.005.

ILO (2018), Supporting Resilient Labour Markets to Drive Inclusive Economic Growth and Decent Work for All, https://www.ilo.org/wcmsp5/groups/public/---ed protect/---protrav/--migrant/documents/genericdocument/wcms 613633.pdf.

ILO/OECD (2019), New job opportunities in an ageing society, Paper prepared for the 1st Meeting of the G20 Employment Working Group, http://www.oecd.org/g20/summits/osaka/ILO-OECD-G20-Paper-1-3-New-job-opportunitiesin-an-ageing-society.pdf.

Irving, P., R. Beamish and A. Burstein (2018), Silver to Gold: The Business of Aging, Milken Institute, https://assets1c.milkeninstitute.org/assets/Publication/ResearchReport/PDF/FINALSilver-to-Gold-0226.pdf.

Joumard, I., C. André and C. Nicq (2010), "Health Care Systems: Efficiency and Institutions", OECD Economics Department Working Papers, No. 769, OECD Publishing, Paris, https://dx.doi.org/10.1787/5kmfp51f5f9t-en.

Khemani, S. (2017), "Political Economy of Reform”, World Bank Policy Research Working Paper, https://openknowledge.worldbank.org/handle/10986/28584. 
Kjerstad, E. and H. Tuntland (2016), "Reablement in community-dwelling older adults: a costeffectiveness analysis alongside a randomized controlled trial", Health Economics Review, Vol. 6/1, http://dx.doi.org/10.1186/s13561-016-0092-8.

Laroque, G. and B. Salanié (2014), "Identifying the Response of Fertility to Financial Incentives", Journal of Applied Econometrics, Vol. 29/2, pp. 314-332, http://dx.doi.org/10.1002/jae.2332.

Lee, R. (2016), "Macroeconomics, Aging, and Growth", in Piggott, J. and A. Woodland (eds.), Handbook of the Economics of Population Aging, North-Holland, http://dx.doi.org/10.1016/BS.HESPA.2016.05.002.

Liang, J. et al. (2014), "Demographics and Entrepreneurship", NBER Working Paper, No. 20506, https://www.nber.org/papers/w20506.

Lisack, N., R. Sajedi and G. Thwaites (2017), "Demographic trends and the real interest rate", Bank of England Staff Working Paper No. 701, https://www.bankofengland.co.uk/workingpaper/2017/demographic-trends-and-the-real-interest-rate.

Lorenzoni, L. et al. (2018), "Which policies increase value for money in health care?", $O E C D$ Health Working Papers, No. 104, OECD Publishing, Paris, https://dx.doi.org/10.1787/a46c5b1f-en.

Marino, A. et al. (2017), "Future trends in health care expenditure: A modelling framework for cross-country forecasts", OECD Health Working Papers, No. 95, OECD Publishing, Paris, http://dx.doi.org/10.1787/247995bb-en.

Muir, T. (2017), "Measuring social protection for long-term care", OECD Health Working Papers, No. 93, OECD Publishing, Paris, http://dx.doi.org/10.1787/a411500a-en.

OECD (2019), Economic Policy Reforms 2019: Going for Growth, OECD Publishing, Paris, https://dx.doi.org/10.1787/aec5b059-en.

OECD (2019), OECD Economic Surveys: Japan 2019, OECD Publishing, Paris, https://dx.doi.org/10.1787/fd63f374-en.

OECD (2019), OECD Employment Outlook 2019: The Future of Work, OECD Publishing, Paris, https://dx.doi.org/10.1787/9ee00155-en.

OECD (2019), Policy Responses to New Forms of Work, OECD Publishing, Paris, https://dx.doi.org/10.1787/0763f1b7-en.

OECD (2019), Society at a Glance 2019: OECD Social Indicators, OECD Publishing, Paris, https://dx.doi.org/10.1787/soc glance-2019-en.

OECD (2019), Will future pensioners work for longer and retire on less?, http://www.oecd.org/els/public-pensions/OECD-Policy-Brief-Future-Pensioners-2019.pdf.

OECD (2018), Financial Incentives and Retirement Savings, OECD Publishing, Paris, https://dx.doi.org/10.1787/9789264306929-en. 
OECD (2018), OECD Economic Surveys: European Union 2018, OECD Publishing, Paris, http://dx.doi.org/10.1787/eco_surveys-eur-2018-en.

OECD (2018), OECD Economic Surveys: Germany 2018, OECD Publishing, Paris, http://dx.doi.org/10.1787/eco_surveys-deu-2018-en.

OECD (2018), OECD Pensions Outlook 2018, OECD Publishing, Paris, https://dx.doi.org/10.1787/pens_outlook-2018-en.

OECD (2018), Pension Markets in Focus, https://www.oecd.org/daf/fin/privatepensions/pensionmarketsinfocus.htm.

OECD (2018), Tax policies for inclusive growth in a changing world, Report to G-20 Finance Ministers and Central Bank Governors,, http://www.oecd.org/g20/Tax-policies-for-inclusivegrowth-in-a-changing-world-OECD.pdf.

OECD (2017), Dare to Share: Germany's Experience Promoting Equal Partnership in Families, OECD Publishing, Paris, https://dx.doi.org/10.1787/9789264259157-en.

OECD (2017), G20/OECD INFE report on adult financial literacy in G20 countries, http://www.oecd.org/daf/fin/financial-education/G20-OECD-INFE-report-adult-financialliteracy-in-G20-countries.pdf.

OECD (2017), G20/OECD INFE Report on ensuring financial education and consumer protection for all in the digital age, http://www.oecd.org/finance/financialeducation/HIGHLIGHTS-G20-OECD-INFE-Report-Financial-education-.

OECD (2017), Health at a Glance 2017: OECD Indicators, OECD Publishing, Paris, https://dx.doi.org/10.1787/health_glance-2017-en.

OECD (2017), "Long-term fiscal cost of tax incentives for private pension plans", Policy brief, http://www.oecd.org/daf/fin/private-pensions/Long-term-fiscal-cost-of-tax-incentives-PolicyBrief-2.pdf.

OECD (2017), Making Integration Work: Assessment and Recognition of Foreign Qualifications, OECD Publishing, Paris, http://dx.doi.org/10.1787/9789264278271-en.

OECD (2017), OECD Economic Surveys: Australia 2017, OECD Publishing, Paris, http://dx.doi.org/10.1787/eco_surveys-aus-2017-en.

OECD (2017), Pension Markets in Focus, https://www.oecd.org/daf/fin/privatepensions/pensionmarketsinfocus.htm.

OECD (2017), Pensions at a Glance 2017: OECD and G20 Indicators, OECD Publishing, Paris, http://dx.doi.org/10.1787/pension_glance-2017-en.

OECD (2017), Preventing Ageing Unequally, OECD Publishing, Paris, http://dx.doi.org/10.1787/9789264279087-en. 
OECD (2017), Tackling Wasteful Spending on Health, OECD Publishing, Paris, https://dx.doi.org/10.1787/9789264266414-en.

OECD (2017), "Tax treatment of retirement savings in private pension plans across OECD countries", Policy brief, http://www.oecd.org/daf/fin/private-pensions/Tax-treatment-ofretirement-savings-Policy-Brief-1.pdf.

OECD (2016), Better Ways to Pay for Health Care, OECD Health Policy Studies, OECD Publishing, Paris, https://dx.doi.org/10.1787/9789264258211-en.

OECD (2016), Effective Carbon Rates: Pricing CO2 through Taxes and Emissions Trading Systems, OECD Publishing, Paris, https://dx.doi.org/10.1787/9789264260115-en.

OECD (2016), "Fragmentation of retirement markets due to differences in life expectancy", Business and Finance Outlook, http://dx.doi.org/10.1787/888933362667.

OECD (2016), G20/OECD INFE International survey of adult financial literacy competencies, https://www.oecd.org/daf/fin/financial-education/OECD-INFE-International-Survey-ofAdult-Financial-Literacy-Competencies.pdf.

OECD (2016), OECD Pensions Outlook 2016, OECD Publishing, Paris, http://dx.doi.org/10.1787/pens outlook-2016-en.

OECD (2015), Fiscal Sustainability of Health Systems: Bridging Health and Finance Perspectives, OECD Publishing, Paris, https://dx.doi.org/10.1787/9789264233386-en.

OECD (2015), OECD Business and Finance Outlook 2015, OECD Publishing, Paris, http://dx.doi.org/10.1787/9789264234291-en.

OECD (2015), OECD Employment Outlook 2015, OECD Publishing, Paris, https://dx.doi.org/10.1787/empl_outlook-2015-en.

OECD (2014), International Migration Outlook, OECD Publishing, Paris, https://doi.org/10.1787/migr_outlook-2014-en.

OECD (2014), Mortality Assumptions and Longevity Risk: Implications for pension funds and annuity providers, OECD Publishing, Paris, http://dx.doi.org/10.1787/9789264222748-en.

OECD (2014), OECD Pensions Outlook 2014, OECD Publishing, Paris, https://dx.doi.org/10.1787/9789264222687-en.

OECD (2014), The Silver Economy as a Pathway for Growth: Insights from the OECD-GCOA Expert Consultation, https://www.oecd.org/sti/the-silver-economy-as-a-pathway-togrowth.pdf.

OECD (2011), Doing Better for Families, OECD Publishing, Paris, https://dx.doi.org/10.1787/9789264098732-en.

OECD (2010), Making Reform Happen: Lessons From OECD Countries, OECD Publishing, Paris, https://doi.org/10.1787/9789264086296-en. 
OECD (2005), Private Pensions OECD Classification and Glossary.

OECD Publishing, P. (ed.) (2019), "Health Spending Projections to 2030: New results based on a revised OECD methodology", OECD Health Working Papers, No. 110.

OECD/ILO/IOM/UNHCR (2018), G20 International Migration and Displacement Trends Report 2018, http://www.oecd.org/els/mig/G20-international-migration-and-displacementtrends-report-2018.pdf.

Paccagnella, M. (2016), "Age, Ageing and Skills: Results from the Survey of Adult Skills", OECD Education Working Papers, No. 132, OECD Publishing, Paris, https://doi.org/10.1787/5jm0q1n38lvc-en.

Pisu, M. (2014), "Overcoming Vulnerabilities of Health Care Systems", OECD Economics Department Working Papers, No. 1132, OECD Publishing, Paris, https://dx.doi.org/10.1787/5jz159228n6j-en.

Rawdanowicz, Ł., M. Hammouch and M. Kasai (2017), "The fall in real long-term government bond yields: Disentangling different drivers", OECD Economics Department Working Papers, No. 1398, OECD Publishing, Paris, http://dx.doi.org/10.1787/cb1ff201-en.

Sarfati, H. and Y. Ghellab (2012), "The political economy of pension reforms in times of global crisis: State unilateralism or social dialogue?", ILO Working Paper No. 37, https://www.ilo.org/ifpdial/information-resources/publications/WCMS 176346/lang-en/index.htm.

Standard and Poor's (2016), Global Aging 2016: 58 Shades Of Gray, https://www.agefiactifs.com/sites/agefiactifs.com/files/fichiers/2016/05/global_aging_2016_58 shades_of gray 28 apr_16.pdf.

Standard and Poor's (2013), Global Aging 2013: Rising To The Challenge, https://www.nact.org/resources/2013 NACT_Global_Aging.pdf.

Thaler, R. and S. Benartzi (2004), "Save More Tomorrow: Using Behavioral Economics to Increase Employee Saving", Journal of Political Economy, Vol. 112/1, pp. 164-187, https://doi.org/10.1086/380085.

Thévenon, O. (2013), "Drivers of Female Labour Force Participation in the OECD", OECD Social, Employment and Migration Working Papers, No. 145, OECD Publishing, Paris, https://dx.doi.org/10.1787/5k46cvrgnms6-en.

Tompson, W. (2009), The Political Economy of Reform: Lessons From Pensions, Product Markets And Labour Markets In Ten OECD Countries, OECD Publishing, Paris, https://doi.org/10.1787/9789264073111-en. 


\section{Annex A.}

Table 3. Structure of retirement-income provision in G20 countries, public and mandatory schemes

\begin{tabular}{|c|c|c|c|c|c|}
\hline & \multirow{2}{*}{ Basic } & \multirow{2}{*}{ Minimum } & \multirow{2}{*}{$\begin{array}{c}\text { Social } \\
\text { assistance }\end{array}$} & Public & \multirow{2}{*}{$\frac{\text { Private }}{\text { Type }}$} \\
\hline & & & & Type & \\
\hline Argentina & $\checkmark$ & $\checkmark$ & $\cdot$ & DB & \\
\hline Australia & $\checkmark$ & $\cdot$ & $\cdot$ & & DC \\
\hline Brazil & $\cdot$ & $\checkmark$ & $\cdot$ & DB & \\
\hline Canada & $\checkmark$ & $\cdot$ & $\checkmark$ & DB & \\
\hline China & $\cdot$ & $\checkmark$ & $\cdot$ & $\mathrm{NDC}+\mathrm{DC}$ & \\
\hline France & $\cdot$ & $\checkmark$ & $\cdot$ & $\mathrm{DB}+$ Points & \\
\hline Germany & $\cdot$ & - & $\cdot$ & Points & \\
\hline India & $\cdot$ & $\checkmark$ & $\cdot$ & $\mathrm{DB}+\mathrm{DC}$ & \\
\hline Indonesia & $\cdot$ & $\cdot$ & $\cdot$ & $\mathrm{DC}$ & \\
\hline Italy & ; & $\checkmark$ & $\cdot$ & NDC & \\
\hline Japan & $\checkmark$ & $\cdot$ & $\cdot$ & DB & \\
\hline Korea & $\cdot$ & ; & $\checkmark$ & DB & \\
\hline Mexico & $\cdot$ & $\checkmark$ & $\cdot$ & & DC \\
\hline Russia & $\checkmark$ & . & $\cdot$ & Points & $D C$ \\
\hline Saudi Arabia & $\cdot$ & $\checkmark$ & $\cdot$ & DB & \\
\hline South Africa & $\checkmark$ & - & $\cdot$ & & \\
\hline Turkey & $\cdot$ & $\checkmark$ & $\cdot$ & DB & \\
\hline United Kingdom & $\checkmark$ & $\cdot$ & $\cdot$ & DB & \\
\hline United States & . & - & . & $\mathrm{DB}$ & \\
\hline
\end{tabular}

Note: $\mathrm{DB}=$ defined benefit; $\mathrm{DC}=$ defined contribution; $\mathrm{NDC}=$ notional accounts. Source: OECD Pensions at a Glance 2017. 
Table 4. Pension designs, objectives and risks

\begin{tabular}{|c|c|c|c|c|c|c|}
\hline & $\begin{array}{l}\text { Public pension } \\
\text { Non-contributory }\end{array}$ & $\begin{array}{l}\text { Public pension } \\
\text { Contributory PAYG }\end{array}$ & $\begin{array}{l}\text { Public pension } \\
\text { Contributory funded }\end{array}$ & $\begin{array}{l}\text { Private funded pension } \\
\text { Mandatory } \mathrm{DB}^{1}\end{array}$ & $\begin{array}{l}\text { Private funded pension } \\
\text { Mandatory DC }\end{array}$ & $\begin{array}{l}\text { Private funded pension } \\
\text { Voluntary }\end{array}$ \\
\hline Poverty relief & $\begin{array}{l}\text { General taxation is the } \\
\text { most equitable and } \\
\text { efficient way of providing } \\
\text { poverty relief in a } \\
\text { redistributive system } \\
\text { Provides backstop } \\
\text { insurance against labour } \\
\text { market, social and } \\
\text { longevity risk } \\
\text { Depends on ability of tax } \\
\text { base to support it }\end{array}$ & $\begin{array}{l}\text { May be used to determine } \\
\text { eligibility for poverty relief } \\
\text { and/or consumption } \\
\text { smoothing } \\
\text { Covers longevity risk }\end{array}$ & Covers longevity risk & Covers longevity risk & $\begin{array}{l}\text { Safeguards required } \\
\text { against resources being } \\
\text { exhausted (longevity risk) } \\
\text { - e.g. compulsory } \\
\text { annuitisation }\end{array}$ & $\begin{array}{l}\text { Not suitable for poverty } \\
\text { relief }\end{array}$ \\
\hline Consumption smoothing & & $\begin{array}{l}\text { May be primary vehicle for } \\
\text { consumption smoothing } \\
\text { for all individuals (e.g. } \\
\text { France) or primarily for } \\
\text { low earners (United } \\
\text { Kingdom) }\end{array}$ & $\begin{array}{l}\text { Contributes to } \\
\text { consumption smoothing } \\
\text { according to the } \\
\text { parameters for } \\
\text { contributions and benefits }\end{array}$ & $\begin{array}{l}\text { Employer and employee } \\
\text { contributions ultimately } \\
\text { come out of salaries } \\
\text { therefore contributes to } \\
\text { consumption smoothing }\end{array}$ & $\begin{array}{l}\text { Direct link between } \\
\text { contributions and benefits } \\
\text { Where private } D C \text { is } \\
\text { partially funded at the } \\
\text { expense of public } \\
\text { contributory } \\
\text { arrangements, the impact } \\
\text { on consumption } \\
\text { smoothing will be reduced }\end{array}$ & $\begin{array}{l}\text { Contributes to } \\
\text { consumption smoothing tr } \\
\text { the extent that savings } \\
\text { into voluntary schemes do } \\
\text { not just divert savings } \\
\text { from other vehicles }\end{array}$ \\
\hline Financial sustainability & $\begin{array}{l}\text { Depending on benefit } \\
\text { level and entittement, may } \\
\text { confict with other } \\
\text { priorities for public } \\
\text { expenditure }\end{array}$ & $\begin{array}{l}\text { Can be vulnerable to } \\
\text { macro-economic and } \\
\text { demographic risks. } \\
\text { Sustainability depends on } \\
\text { benefit levels, retirement } \\
\text { age, indexation } \\
\text { Transition to funded } \\
\text { systems can worsen } \\
\text { sustainability of PAYG } \\
\text { systems }\end{array}$ & $\begin{array}{l}\text { Can be vulnerable to } \\
\text { macro-economic and } \\
\text { demographic risks. NDC } \\
\text { may improve sustainability } \\
\text { by closely linking benefits } \\
\text { to contributions } \\
\text { Potential for operational } \\
\text { risks } \\
\text { Transition from PAYG to } \\
\text { partial funding can make } \\
\text { the PAYG system less } \\
\text { sustainable }\end{array}$ & $\begin{array}{l}\text { Vulnerable to } \\
\text { demographic risks and } \\
\text { low interest rates Potential } \\
\text { for operational risks }\end{array}$ & $\begin{array}{l}\text { Sustainability achieved by } \\
\text { pushing more risk onto } \\
\text { individuals - creates a } \\
\text { requirement for a public } \\
\text { system to provide some } \\
\text { insurance } \\
\text { Potential for operational } \\
\text { risks }\end{array}$ & Fully sustainable \\
\hline Redistribution & $\begin{array}{l}\text { Part of progressive } \\
\text { taxation. Means testing } \\
\text { can increase redistribution } \\
\text { effect }\end{array}$ & $\begin{array}{l}\text { Can adjust parameters to } \\
\text { increase redistribution e.g. } \\
\text { link between contributions } \\
\text { and benefits, floors and } \\
\text { ceilings, accrual rates, } \\
\text { indexation }\end{array}$ & $\begin{array}{l}\text { Can adjust parameters to } \\
\text { increase redistribution e.g. } \\
\text { link between contributions } \\
\text { and benefits, floors and } \\
\text { ceilings, accrual rates, } \\
\text { indexation }\end{array}$ & $\begin{array}{l}\text { Not an objective of DB } \\
\text { schemes } \\
\text { Tax incentives may be } \\
\text { less progressive than } \\
\text { overall tax system }\end{array}$ & $\begin{array}{l}\text { Not possible within } \\
\text { individual DC schemes } \\
\text { Tax incentives may be } \\
\text { less progressive than } \\
\text { overall tax system }\end{array}$ & $\begin{array}{l}\text { Not possible within } \\
\text { individual DC schemes } \\
\text { Tax incentives may be } \\
\text { less progressive than } \\
\text { overall tax system }\end{array}$ \\
\hline Inter-generational equity & Within tax system & $\begin{array}{l}\text { Demographic changes } \\
\text { mean redistribution from } \\
\text { current contributors to } \\
\text { current retirees. This can } \\
\text { be offset by adjusting } \\
\text { benefit levels and accruals } \\
\text { - this shifts part of macro- } \\
\text { economic and longevity } \\
\text { risk onto individuals }\end{array}$ & $\begin{array}{l}\text { Demographic changes } \\
\text { mean redistribution from } \\
\text { current contributors to } \\
\text { current retirees. This can } \\
\text { be offset by adjusting } \\
\text { benefit levels and accruals } \\
\text { - this shifts part of macro- } \\
\text { economic and longevity } \\
\text { risk onto individuals }\end{array}$ & $\begin{array}{l}\text { Longevity risk shared } \\
\text { across generations. Risk } \\
\text { sharing mechanisms can } \\
\text { be introduced }\end{array}$ & $\begin{array}{l}\text { Not possible within } \\
\text { individual DC }\end{array}$ & $\begin{array}{l}\text { Not possible within } \\
\text { individual DC }\end{array}$ \\
\hline Intra-generational equity & & $\begin{array}{l}\text { Can use compensatory } \\
\text { mechanisms to offset } \\
\text { missed contribution } \\
\text { periods - therefore } \\
\text { provides insurance } \\
\text { against labour market and } \\
\text { social risks. However this } \\
\text { may be interpreted as a } \\
\text { right so weakens incentive } \\
\text { to contribute }\end{array}$ & $\begin{array}{l}\text { Can use compensatory } \\
\text { mechanisms to offset } \\
\text { missed contribution } \\
\text { periods - therefore } \\
\text { provides insurance against } \\
\text { labour market and social } \\
\text { risks }\end{array}$ & $\begin{array}{l}\text { Collective systems can } \\
\text { provide insurance against } \\
\text { labour market and social } \\
\text { risks }\end{array}$ & $\begin{array}{l}\text { Not possible within } \\
\text { individual DC } \\
\text { Insurance against labour } \\
\text { market and social risks } \\
\text { can be purchased but at a } \\
\text { higher cost than in a } \\
\text { collective arrangement }\end{array}$ & $\begin{array}{l}\text { Not possible within } \\
\text { individual DC }\end{array}$ \\
\hline $\begin{array}{l}\text { Benefit } \\
\text { adequacylreplacement } \\
\text { rate }\end{array}$ & $\begin{array}{l}\text { Can be set as minimum or } \\
\text { target replacement rate } \\
\text { for average earner (note } \\
\text { potential fiscal } \\
\text { implications) }\end{array}$ & $\begin{array}{l}\text { Can be used for minimum } \\
\text { income guarantee or for } \\
\text { target replacement rate } \\
\text { Target may vary by } \\
\text { income level }\end{array}$ & $\begin{array}{l}\text { Target replacement rate } \\
\text { may vary by income level. }\end{array}$ & $\begin{array}{l}\text { Target replacement rate, } \\
\text { though increasing move } \\
\text { towards conditional } \\
\text { indexation i.e. less } \\
\text { protection against macro- } \\
\text { economic risk }\end{array}$ & $\begin{array}{l}\text { Vulnerable to macro- } \\
\text { economic, financial } \\
\text { market and operational } \\
\text { risks. Investment strategy } \\
\text { has significant impact on } \\
\text { benefit levels. }\end{array}$ & $\begin{array}{l}\text { Generally used to } \\
\text { increase replacement rate } \\
\text { for higher earners }\end{array}$ \\
\hline $\begin{array}{l}\text { Labour force } \\
\text { participation }\end{array}$ & May weaken incentives & $\begin{array}{l}\text { May reduce incentives to } \\
\text { work past retirement age: } \\
\text { close routes to early } \\
\text { retirement and align age } \\
\text { at which public and private } \\
\text { benefits can be accessed }\end{array}$ & $\begin{array}{l}\text { Incentive depends on link } \\
\text { between contributions and } \\
\text { benefits: close routes to } \\
\text { early retirement and align } \\
\text { age at which public and } \\
\text { private benefits can be } \\
\text { accessed }\end{array}$ & $\begin{array}{l}\text { Uniform accrual rates } \\
\text { penalise younger } \\
\text { workers/those with less } \\
\text { seniority - DB may be } \\
\text { less adaptable to } \\
\text { changing labour market } \\
\text { conditions }\end{array}$ & Strong incentive & $\begin{array}{l}\text { Limited incentive, unless } \\
\text { no other savings vehicle } \\
\text { available }\end{array}$ \\
\hline Coverage & Universal & $\begin{array}{l}\text { Excludes people who } \\
\text { have never participated in } \\
\text { formal economy }\end{array}$ & $\begin{array}{l}\text { Can be extended to all } \\
\text { workers within formal } \\
\text { economy relatively easily }\end{array}$ & $\begin{array}{l}\text { Tend to exclude the low- } \\
\text { paid, part-time workers, } \\
\text { self-employed }\end{array}$ & $\begin{array}{l}\text { Tend to exclude the low- } \\
\text { paid, part-time workers, } \\
\text { self-employed }\end{array}$ & $\begin{array}{l}\text { Generally used by higher } \\
\text { eamers. Incentives such } \\
\text { as matching contributions } \\
\text { can encourage more } \\
\text { people to participate }\end{array}$ \\
\hline
\end{tabular}

Note: 1. Applies also to voluntary DB where applicable (e.g. Canada, United Kingdom).

Source: OECD Pensions Outlook 2018. 
Table 5. Recent pension reforms

\begin{tabular}{ll}
\hline Country & Retirement age \\
\hline & \\
Argentina & \\
& \\
& -2009: Increase in pension age \\
& from age 65 to 67 starting from \\
& 2017 until 2023.
\end{tabular}

Australia from age 65 to 67 starting from

$\begin{array}{ll} & \text { - 2016: The age of eligibility will } \\ & \text { remain at } 65 \text { instead of } \\ \text { previously planned increase } \\ \text { from age } 65 \text { to } 67 \text { from } 2023 \text { to } \\ \text { Canada } & 2029 .\end{array}$

Chile

\section{- 201:4 Increase in the} contribution period for a full pension until it reaches 43 years in 2035 .

-2014: Possibility for a person having contributed a full period to retire without any penalty from the age of 60 .

- 2012: Increase in the minimum pension age from 60 to 62 by

France 2017.

- 2012: Possibility for workers to retire early at 60 with full contributory periods.

- 2012: Increase in the publicsector workers' contribution years for a full pension.

- 2011: Increase in the age for a full rate pension regardless of contribution period from 65 to 67.
- 2017: Paring back tax concessions including reduction of annual contribution ceiling from 2017.

- 2013: Increase in mandatory DC contributions between 2013 and 2020

- 2016: Increase in pension benefits of Canada Pension Plan from around $1 / 4$ to around $1 / 3$ of workers' average monthly pensionable earnings from 2019 to 2025 .

- 2011: Abolition of healthcare contribution for low-income pensioners and reduced contribution for middle-to-high income retirees.
- 2016: Increase in contribution rates from $4.95 \%$ (2019) to around $5.95 \%$ (2023).

\section{Coverage}

- 2017: Workers can work until the age of 70 and accumulate additional pension rights for doing so.

- 2013: Abolition of age limit on compulsory contributions to private pension schemes.

- 2013: Introduction of a new voluntary retirement savings plan based on autoenrolment, adopted between 2013 and 2015.
- 2016: Agreement between social partners to increase temporarily the cost of a point used to calculate an individual's pension benefits by 2 percentage points annually from 2016 to 2018 , beyond the usual wage indexation.

- 2016: The timetable for adjusting mandatory occupational pensions pushed back from April to November each year and the formula for adjusting pensions is extended for another two years.

\begin{abstract}
- 2012-2014: Automatic enrolment of selfemployed with the option to opt out and obligation to contribute from 2015.

- 2011: Inclusion of $60 \%$ of the poorest elderly people into the first-pillar solidarity pension system from 2011.

- 2011: New rules for employer-sponsored voluntary private pension arrangements to incentivise enrolment and State provision of an annual subsidy to voluntary retirement savings.
\end{abstract}

- 2014: Contribution period used for benefit computation more generous for maternity, training, unemployment, apprenticeships, students and part-time work.

- 2010: Cash maternity benefits count as earnings for pension purposes. 


\section{Country Retirement age}

2014: Reduction of the retirement age from 65 to 63 for people with 45 contributory years. Increase of this age from 2016 by two months a year until it reaches 65 .

- 2007: Increase in normal pension age from 65 to 67 between 2012 and 2029 .

\section{- 2015: The pension age will} increase from 56 to 57 in 2019 and then increase by one year for every three years until it reaches 65 years in 2043.

- 2011: Pension age increase for women from age 60 to 66 , to match that of men by 2018; pension age for both sexes due to increase in line with life

Pension benefits

- 2014: Parents will receive pension credits for the first two years of their child's life.

Contributions

- 2017: Decrease of the age at which workers may make compensatory payments (to boost early pensions) from 55 to 50 .
- 2017: Individuals who work after the normal retirement age can choose to continue paying pension contributions for higher benefits.
-2017: Increase in the 14th-month payment for low pensions.
- 2015: Creation of a mandatory pay-as-you-go defined benefit scheme. The new scheme was introduced on top of the existing mandatory defined contribution scheme.

\author{
- 2016: improvement of the rules \\ for applying "macroeconomic \\ indexation". This rule adjusts \\ pension benefits based on \\ changes in the number of \\ contributors and life expectancy. \\ - 2016: From 2018, inclusion of \\ the periods of deflation in the \\ indexation rules, but any \\ unrealised benefit reduction \\ because of a deflationary \\ environment will now be delayed \\ to the next fiscal year or later, \\ when the unused reduction can be \\ applied with consumer price \\ inflation. \\ -2016: From 2021 revision of the \\ Wage/Price Indexation: pensions \\ are adjusted downward when \\ wages decline. \\ - 2014: The ad hoc nominal freeze \\ of pension benefits is abolished \\ and a new wage and price \\ indexation is being introduced \\ from 2015 \\ - 2014: Provision of low-income, \\ old age pensioners with welfare \\ benefits from 2017.
}

- 2017: Restrictions on individual DC plan participation will be removed to allow contributions from non-working spouses, publicsector workers, and individuals currently covered only by private DB plans.

- Mandatory coverage of part-time employees will be extended to companies with fewer than 500 employees.

- For corporate pensions, employees can contribute directly to employer- provided DC plans without having to go through their employers from January 2012.

- 2014: Reduction of the qualifying period for the national pension from 25 to 10 years from 2017.

- Extension of coverage of voluntary DC plans to workers aged 60 and above from 2012. - 2012: Shorten the period needed to be eligible for the national pension from 25 to 10 years from 2015.

- 2012: Extend employees' pension insurance to more part-time workers from 2016

- 2012: Extend the basic pension for surviving family to motherless families from 2014.

- Reduction of the qualifying period for the national pension from 25 to 10 years from 2017. 


\begin{tabular}{|c|c|c|c|}
\hline Country & Retirement age & Pension benefits & Contributions \\
\hline Korea & & $\begin{array}{l}\text { - 2018: Further increase in the } \\
\text { Basic Pension. } \\
\text { - 2014: The Basic Pension (a first- } \\
\text { tier tax-financed benefit) doubled } \\
\text { to } 5.3 \% \text { of the average wage in } \\
2016 . \\
\text {. }\end{array}$ & $\begin{array}{l}\text { - 2017: The government: i) allowed } \\
\text { insured persons who take a career } \\
\text { break due to childbirth or childcare to } \\
\text { make deferred National Pension } \\
\text { System contributions ii) introduced } \\
\text { subsidies of } 75 \% \text { for NPS } \\
\text { contributions paid by the } \\
\text { unemployed; and subsidy of } 90 \% \\
\text { (80\%) of NPS contributions for } \\
\text { newly-insured employees at firms } \\
\text { with less than five (five to nine) } \\
\text { workers. }\end{array}$ \\
\hline
\end{tabular}

\begin{tabular}{|c|c|c|}
\hline \multicolumn{3}{|l|}{ Mexico } \\
\hline Netherlands & $\begin{array}{l}\text { - 2016: Increase in the } \\
\text { retirement age for the basic } \\
\text { pension to reach } 67 \text { in } 2021 . \\
\text { After that it will be linked to life } \\
\text { expectancy. } \\
\text { - 2014: Increase of the } \\
\text { retirement age for occupational } \\
\text { pensions from } 65 \text { to } 67 \text {. Early } \\
\text { retirement for physically } \\
\text { demanding occupations } \\
\text { conditions are being phased out. }\end{array}$ & $\begin{array}{l}\text { - 2016: DC pension plan } \\
\text { participants will be able to choose } \\
\text { between: 1) a fixed annuity } \\
\text { providing a guaranteed level of } \\
\text { income until the end of life; 2) a } \\
\text { variable annuity that allows } \\
\text { retirees to invest in risk-bearing } \\
\text { assets and provides a level of } \\
\text { income that is adjusted according } \\
\text { to the performance; or 3) a } \\
\text { combination of the both. }\end{array}$ \\
\hline
\end{tabular}

- 2018: Increase of the retirement age from 60 to 65 for men and 55 to 60 for women, in steps of 6 months per year and starting 2019.

- 2013: New non-contributory pension is established for Mexicans older than 65 years and with no other pension.

- 2017: Expansion of the eligibility for the Individual Retirement Pension to include selfemployed individuals and public officials - 2014: New basic pension introduced in July 2014.

- 2009: Expansion of mandatory occupational/severance-pay plans to firms with 5 or less workers from 2010.

\section{- 2011: Normal pension age to increase from 65 to 67 between 2013 and 2027 but full benefits will be available at age 65 with 38.5 years of contributions, starting from 2013.}

- 2011: Increase in the early pension age from 61 to 63 and increase in contribution years for full benefit from 30 to 33 years for early retirement.

- 2011: Workers close to retirement age can work parttime and receive a proportionally reduced pension. However, social security contributions must be paid based on a fulltime position.

\author{
- 2016: Introduction of new \\ "maternity complement". This new \\ complement is applicable to all \\ new contributory pensions \\ recognised to women with \\ children. \\ - 2014: A new Adjustment \\ Pensions Index (IRP) is applied \\ from 2014 and a Sustainability \\ Factor (FS) will be introduced in \\ 2019 and will be applicable to new \\ pension benefits. This factor takes \\ into account the growth of the life \\ expectancy of the new \\ pensioners. \\ - 2011: Incentives for work after \\ retirement age: pension increase \\ of 2-4\% for each year of deferred \\ pension.
}




\begin{tabular}{|c|c|c|c|c|}
\hline Country & Retirement age & Pension benefits & Contributions & Coverage \\
\hline Switzerland & & $\begin{array}{l}\text { - 2015-2017: Reduction in the } \\
\text { minimum interest rate on } \\
\text { mandatory private pensions from } \\
1.75 \% \text { in } 2015 \text { to } 1.25 \% \text { in } 2016 \\
\text { and to } 1 \% \text { in } 2017 \text {. } \\
\text { - 2009: Reduction in the minimum } \\
\text { rate of return on mandatory } \\
\text { private pensions and to } 1.5 \% \text { from } \\
2012 \text {. }\end{array}$ & $\begin{array}{l}\text { - 2018: Increase in the social } \\
\text { contributions by } 0.3 \text { percentage } \\
\text { points (half from employers, half from } \\
\text { employees). }\end{array}$ & \\
\hline Turkey & $\begin{array}{l}\text { - 2006: Pension age to increase } \\
\text { from } 60 \text { to } 65 \text { for men and from } \\
58 \text { to } 65 \text { for women by } 2048 \text {. }\end{array}$ & & & $\begin{array}{l}\text { - 2017: Automatic enrolment of all wage- } \\
\text { earners younger than } 45 \text { into private DC } \\
\text { pension plans. Employees will automatically } \\
\text { contribute } 3 \% \text { of their gross income to private } \\
\text { pension plans chosen by their employers. } \\
\text { Employees can choose to opt out (within the } \\
\text { first two months). The Government will match } \\
25 \% \text { of an employee's contributions and will } \\
\text { make an additional one-time contribution for } \\
\text { those who do not opt out. }\end{array}$ \\
\hline $\begin{array}{l}\text { United } \\
\text { Kingdom }\end{array}$ & $\begin{array}{l}\text {-2014: Pension age increase to } \\
66 \text { by } 2026 \text { and to } 67 \text { by } 2028 \\
-2014 \text { Gradual increase of the } \\
\text { private pension age from } 55 \text { to } \\
57 \text { in } 2028 \text {. Private pension will } \\
\text { be available for withdrawal from } \\
10 \text { years before the normal } \\
\text { pension age } \\
\text { - } 2010-12 \text { : Pension ages } \\
\text { equalised at } 65 \text { by } 2018 \text {. } \\
\text { Increase in pension age to } 66 \text { by } \\
2020 \text { and to } 67 \text { by } \\
2026 . \text { Removal of the default } \\
\text { retirement age of } 65 \text { to provide } \\
\text { workers with greater } \\
\text { opportunities to remain in the } \\
\text { labour market afterwards. From } \\
2011 \text {, employers cannot compel } \\
\text { employees to retire using the } \\
\text { default retirement age. }\end{array}$ & $\begin{array}{l}\text { - From 2016, a new state pension } \\
\text { will replace at a higher level both } \\
\text { the basic pension and the } \\
\text { minimum income guarantee. }\end{array}$ & $\begin{array}{l}\text { - 2012: Following the auto enrolment } \\
\text { reform, contributions will be } \\
\text { increased from total of } 2 \% \text { of } \\
\text { earnings in } 2012 \text { to } 5 \% \text { in } 2016 \text { and } \\
8 \% \text { in } 2017 \text {. }\end{array}$ & $\begin{array}{l}\text { - 2016: National Employment Savings Trust } \\
\text { (NEST) extended to small employers. } \\
\text { - 2012: Large employers must automatically } \\
\text { enrol workers in company scheme or state-run } \\
\text { National Employment Savings Trust (NEST) } \\
\text { scheme from 2012; medium-sized employers } \\
\text { from 2013, and small employers from } 2015 \text {. } \\
\text { Under auto-enrolment, the employer enrols all } \\
\text { employees in a workplace pension scheme, to } \\
\text { which the employer must make a minimum } \\
\text { contribution; employees have the option of } \\
\text { opting out of the scheme. }\end{array}$ \\
\hline $\begin{array}{l}\text { United } \\
\text { States }\end{array}$ & & $\begin{array}{l}\text { - Automatic adjustment of } \\
\text { pensions to inflation suspended in } \\
2010 \text { to avoid lowering benefits. } \\
\text { However, benefit increase was } \\
\text { frozen in } 2011 .\end{array}$ & & $\begin{array}{l}\text { - 2014: My retirement accounts (myRAs) were } \\
\text { announced in January } 2014 \text { to encourage more } \\
\text { to save for retirement. Contributions will be } \\
\text { invested in government bonds and the principal } \\
\text { is guaranteed. }\end{array}$ \\
\hline
\end{tabular}

